UNIVERSIDADE DE SÃO PAULO

FACULDADE DE MEDICINA DE RIBEIRÃO PRETO

PROGRAMA DE PÓS-GRADUAÇÃO EM GENÉTICA

MAX JORDAN DE SOUZA DUARTE

O gene Aire pode controlar mRNAs bem como os IncRNAs em células tímicas epiteliais medulares como evidenciado pela edição do genoma por CRISPR-Cas9.

Ribeirão Preto - SP

2018 
O gene Aire pode controlar mRNAs bem como os IncRNAs em células tímicas epiteliais medulares como evidenciado pela edição do genoma por CRISPR-Cas9.

Dissertação apresentada ao programa de Pósgraduação em Genética da Faculdade de Medicina de Ribeirão Preto, da Universidade de São Paulo, para obtenção do título de Mestre em Ciências. Versão corrigida. A versão original encontra-se disponível tanto na Biblioteca da Unidade que aloja o Programa, quanto na Biblioteca Digital de Teses e Dissertações da USP (BDTD).

Área de concentração: Genética

Orientador: Prof. Dr. Geraldo Aleixo da Silva Passos Júnior 


\section{AUTORIZO A REPRODUÇÃO E DIVULGAÇÃO TOTAL OU PARCIAL DESTE TRABALHO, POR QUALQUER MEIO CONVENCIONAL OU ELETRÔNICO, PARA FINS DE ESTUDO E PESQUISA, DESDE QUE CITADA A FONTE.}

\section{Catalogação da Publicação}

Duarte, Max Jordan

O gene Aire pode controlar mRNAs bem como os IncRNAs em células tímicas epiteliais medulares como evidenciado pela edição do genoma por CRISPR-Cas9.

Ribeirão Preto, 2018.

$119 p$.

Dissertação de Mestrado, apresentada à Faculdade de Medicina de Ribeirão Preto da Universidade de São Paulo. Área de concentração: Genética

1. Células tímicas epiteliais medulares (mTECs). 2. Gene Autoimmune Regulator (Aire). 3. CRISPR-Cas9 4. Long noncoding RNA. 5. Expressão Gênica 6. Adesão Celular 


\section{APOIO E SUPORTE FINANCEIRO}

Este trabalho foi realizado no Laboratório de Imunogenética Molecular, localizado no Departamento de Genética da Faculdade de Medicina de Ribeirão Preto (FMRP), da Universidade de São Paulo (USP), com o apoio ou suporte financeiro das seguintes instituições:

- Fundação de Amparo à Pesquisa do Estado do São Paulo (FAPESP) por meio do Projeto Individual Processo 13/17481-1;

- Conselho Nacional de Desenvolvimento Científico e Tecnológico (CNPq);

- Coordenação de Aperfeiçoamento de Pessoal de Nível Superior (CAPES);

- Faculdade de Medicina de Ribeirão Preto - FMRP - USP. 
Nome: DUARTE, Max Jordan de Souza

Título: O gene Aire pode controlar mRNAs bem como os IncRNAs em células tímicas epiteliais medulares como evidenciado pela edição do genoma por CRISPR-Cas9.

Dissertação apresentada ao Programa de Pós-graduação em Genética da Faculdade de Medicina de Ribeirão Preto, da Universidade de São Paulo, para obtenção do título de Mestre em Ciências.

Aprovada em:

Banca Examinadora

Prof. Dr.

Instituição:

Assinatura:

Prof. Dr.

Instituição:

Assinatura:

Prof. Dr.

Instituição: Assinatura: 
Dedico esse trabalho

A ciência e a pesquisa do nosso Brasil 


\section{Agradecimentos}

Agradeço, a minha família, que mesmo sem entender meus objetivos, confiam em mim e regam de amor, carinho, orgulho e admiração;

Agradeço, ao meu pai Jorge Duarte, que me deu apoio em todas as importantes decisões da minha vida e transfigura um grande exemplo de ser humano, me ensinando mesmo em silêncio. Amo sua vida e sou eternamente grato a Deus e a você por tudo.

Agradeço, ao apoio de amigos espalhados por diversas cidades, estados e países, em quem sempre encontro uma palavra alegre, de otimismo, ajuda e apoio.

Agradeço, aos amigos do Laboratório de Imunogenética Molecular, por todo o conhecimento compartilhado ao longo desses anos, companhias essenciais para o crescimento profissional e pessoal.

Agradeço, ao Prof. Geraldo Passos, que respira ciência e nos inspira todos os dias. A ciência carece de cientistas como você. Sou imensamente grato pela oportunidade e confiança depositada para que um bom trabalho fosse feito. 
"Por mais que agora não se consiga elucidar as etapas que nos confrontam, sei que um mar de entendimentos está por vir" 


\section{RESUMO}

Duarte, Max Jordan. O gene Aire pode controlar mRNAs bem como os IncRNAs em células tímicas epiteliais medulares como evidenciado pela edição do genoma por

CRISPR-Cas9. 2018. Dissertação de Mestrado, Faculdade de Medicina de Ribeirão Preto, Universidade de São Paulo, Ribeirão Preto.

O timo é um órgão linfoide primário essencial para a manutenção da tolerância central através da seleção e eliminação de células T autoreativas. Precursores de células $T$, oriundas da medula óssea, chegam ao timo e migram do córtex para região da medula. As células epiteliais medulares tímicas (mTECs) expressam em sua superfície antígenos de tecidos periféricos (em inglês tissue-restricted antigens ou TRAs) que representam autoantígenos de todos os tecidos do corpo. Atuando como um fator de transcrição não clássico em células mTEC, o gene Autoimmune Regulator (Aire) desempenha um papel na expressão dos TRAs, cuja proteína codificada libera a RNA polimerase II (RNA Pol II) ancorada na cromatina e regula a expressão de mRNAs na glândula timo. A função biológica deste gene está ligada à indução de tolerância imunológica central impedindo o aparecimento de doenças autoimunes. Isso é resultado da seleção negativa de timócitos (precursores de células T) autoreativos que interagem fisicamente com as mTECs. Os timócitos autoreativos que reconhecem os TRAs como elementos estranhos são eliminados por apoptose. O co-cultivo de mTECs com timócitos representa um sistema-modelo in vitro adequado para se aproximar da interação celular que ocorre dentro do timo. Os resultados anteriores do nosso laboratório demonstraram que além do controle de mRNA de TRAs, o gene Aire também participa da modulação de miRNAs em mTECs uma vez que estas espécies de RNA são transcritas pela RNA Pol II. Continuando com essa linha de estudos, neste trabalho nós demonstramos pela primeira vez que Aire também modula a expressão de long noncoding RNAs (IncRNAs) em mTECs. Para isto fizemos uso da estratégia da perda de função analisando a expressão dessa espécie de RNA, assim como de mRNAs, em células mTEC Aire +/+ e mTEC Aire nocautes (KO Aire -/-) obtidas pela edição gênica por Crispr-Cas9. O transcriptoma dessas células que passaram ou não por adesão com timócitos, foi então analisado por hibridizações com microarrays. Isso evidenciou que Aire e adesão celular influenciam a expressão tanto de mRNAs como de IncRNAs. A reconstrução de redes de interação IncRNAs-mRNAs possibilitou evidenciar uma nova via de regulação pós-transcricional em células mTEC. Palavras-chave Células tímicas epiteliais medulares (mTECs), Gene Autoimmune Regulator (Aire), CRISPR-Cas9, Long noncoding RNA, Expressão Gênica, Adesão Celular. 


\begin{abstract}
Duarte, Max Jordan. Aire gene can control mRNAs as well as IncRNAs in medullary thymic epitelial cells as evidentiated by genome editing by CRISPR-Cas9. 2018. Dissertação de Mestrado, Faculdade de Medicina de Ribeirão Preto, Universidade de São Paulo, Ribeirão Preto.

The thymus is a primary lymphoid organ essential for the maintenance of central tolerance through the selection and elimination of autoreactive $T$ cells. Precursors of $T$ cells, originating from the bone marrow, reach the thymus and migrate from the thymic cortex to the medullary region. Thymic medullary epithelial cells (mTECs) express on their surface tissue-restricted antigens (TRAs) that represent autoantigens of all tissues in the body. Acting as a non-classical transcription factor in mTEC cells, the Autoimmune regulator (Aire) gene plays a role in the expression of TRAs, whose encoded protein releases the RNA polymerase II (RNA Pol II) anchored in the chromatin and regulates the expression of mRNAs in the thymus gland. The biological function of this gene is associated to the induction of central immune tolerance preventing the onset of autoimmune diseases. This is a result of negative selection of autoreactive thymocytes (T cell precursors) that interact physically with mTECs. Self-reactive thymocytes that recognize TRAs as foreign elements are eliminated by apoptosis. The co-culture of mTECs with thymocytes represents an appropriate in vitro model system to approximate the cellular interaction that occurs within the thymus. Previous results from our laboratory demonstrated that in addition to the control of TRA mRNAs, Aire also participates in the modulation of miRNAs in mTECs since these RNA species are transcribed by RNA Pol II. Continuing with this line of studies, in this study we demonstrate for the first time that Aire also modulates the expression of long non-coding RNAs (IncRNAs) in mTECs. For this, we used the loss-of-function strategy to analyze the expression of this RNA species, as well as mRNAs in mTEC Aire + / + or Aire knockout mTEC cells (KO Aire - / -) obtained by the gene editing by Crispr-Cas9. The transcriptome of these cells, whether or not adhered to thymocytes, was then analyzed by microarray hybridizations. This demonstrated that Aire and cell adhesion influence the expression of both mRNAs and IncRNAs. The reconstruction of IncRNAs-mRNAs interaction networks made possible to evidence a new post-transcriptional regulation pathway in mTEC cells. Keywords Medullary thymic epithelial cells (mTECs), Autoimmune Regulator (AIRE), CRISPRCas9, Long noncoding RNA, Gene expression, Cell adhesion.
\end{abstract}




\section{LISTA DE FIGURAS}

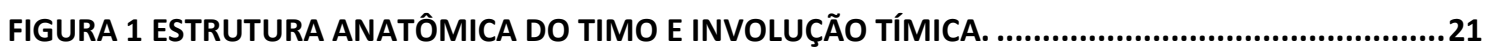

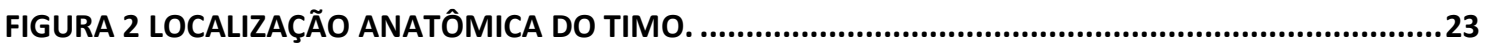

FIGURA 3 MECANISMOS DE SELEÇÃO NEGATIVA E POSITIVA NO AMBIENTE TÍMICO. ............................23

FIGURA 4 DIVERSIDADE DE ANTÍGENOS PRÓPRIOS EXPRESSOS EM CÉLULAS MTECS............................27

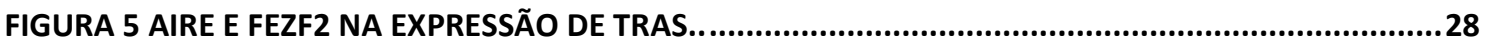

FIGURA 6 GRÁFICO REPRESENTANDO A PROPORÇÃO DE TRAS EM MTECS REGULADOS PELOS GENES

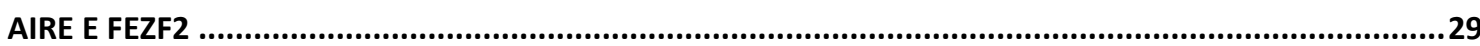

FIGURA 7 REGIÕES CODIFICANTES DO GENE AIRE EM HUMANOS E CAMUNDONGOS E SEUS

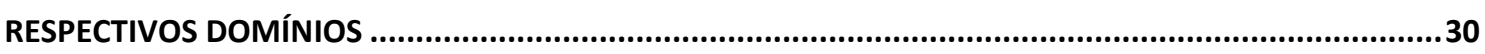

FIGURA 8 INDUÇÃO DA PGE VIA AIRE EM ASSOCIAÇÃO COM OUTRAS PROTEÍNAS. ..............................32

FIGURA 9 DESCRIÇÃO DOS PRINCIPAIS SINAIS CLÍNICOS APRESENTADOS NO ESTABELECIMENTO DA

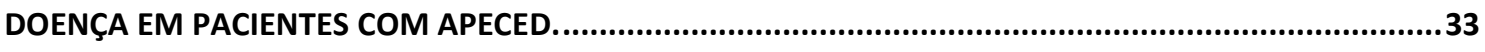

FIGURA 10 MUTAÇÕES DESCRITAS NOS DOMÍNIOS FUNCIONAIS DA PROTEÍNA AIRE ...........................34

FIGURA 11 ESTRUTURA E INTERAÇÃO DOS LNCRNAS. ...........................................................................

FIGURA 12 DIFERENTES INTERAÇÕES ENTRE LNCRNA E MIRNA. ........................................................

FIGURA 13 CLASSIFICAÇÃO DE ACORDO COM A LOCALIZAÇÃO DOS LNCRNAS.. ....................................39

FIGURA 14 WESTERN BLOT DA PROTEÍNA AIRE EM MTECS KO E WT. ...................................................61

FIGURA 15 CO-CULTIVO DE MTECS - TIMÓCITOS MOSTRADOS POR UMA MICROFOTOGRAFIA. ..........62

FIGURA 16 ANÁLISE DO ÍNDICE DE ADESÃO ENTRE MTECS - TIMÓCITOS. ........................................62

FIGURA 17 ANÁLISE QUANTITATIVA DOS GENES DIFERENCIALMENTE EXPRESSOS. ................................63

FIGURA 18 HEATMAP EVIDENCIANDO O PERFIL DE EXPRESSÃO DOS GENES DIFERENCIALMENTE

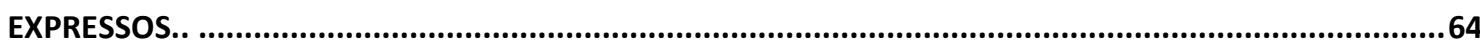

FIGURA 19 TOP GENES CODIFICADORES DE PROTEÍNA DIFERENCIALMENTE EXPRESSOS EM MTEC WT

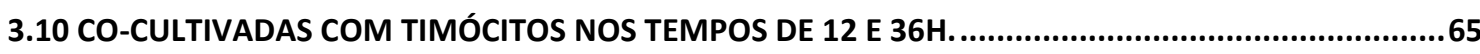

FIGURA 20 ANÁLISE IN SILICO (A-D) DOS PROCESSOS BIOLÓGICOS DOS MRNAS MODULADOS NAS CÉLULAS MTECS WT EM CO-CULTIVO COM TIMÓCITOS NOS TEMPOS DE 12 E 36H .............................67

FIGURA 21 ANÁLISE QUANTITATIVA DOS VALORES DE EXPRESSÃO EM CÉLULAS MTEC 3.10 KO PARA O

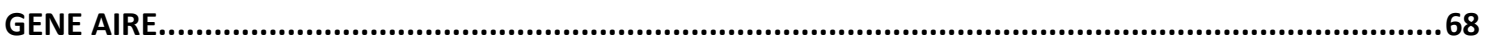

FIGURA 22 HEATMAP DO AGRUPAMENTO HIERÁRQUICO DOS MRNAS MODULADOS NAS CÉLULAS MTECS KO PARA O GENE AIRE EM CO-CULTIVO COM TIMÓCITOS NOS TEMPOS DE 12 E 36H...............69

FIGURA 23 TOP GENES LONGO NÃO CODIFICANTES DIFERENCIALMENTE EXPRESSOS EM MTEC AIRE \%

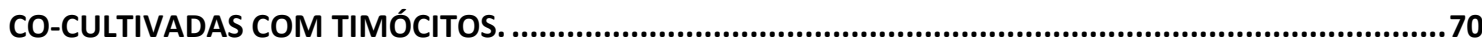

FIGURA 24 ANÁLISE IN SILICO DOS PROCESSOS BIOLÓGICOS ENVOLVIDOS NAS CÉLULAS MTECS KO PARA O GENE AIRE EM CO-CULTIVO COM TIMÓCITOS NOS TEMPOS DE 12 E 36H 
FIGURA 25 HEATMAP DOS LNCRNAS MODULADOS NAS CÉLULAS MTECS WT EM CO-CULTIVO COM TIMÓCITOS.

FIGURA 26 TOP RNAS LONGO NÃO CODIFICANTES (LNCRNAS) DIFERENCIALMENTE EXPRESSOS EM MTEC 3.10 WT CO-CULTIVADAS COM TIMÓCITOS.

FIGURA 27 HEATMAP DO AGRUPAMENTO HIERÁRQUICO NÃO SUPERVISIONADO DOS LNCRNAS MODULADOS NAS CÉLULAS MTECS AIRE ${ }^{-/}$PARA O GENE AIRE EM CO-CULTIVO COM TIMÓCITOS .......75 FIGURA 28 TOP RNAS LONGO NÃO CODIFICANTES (LNCRNAS) DIFERENCIALMENTE EXPRESSOS EM

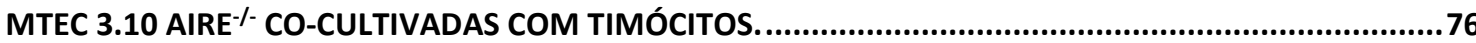
FIGURA 29 CLASSIFICAÇÃO E DISTRIBUIÇÃO E DOS LNCRNA MODULADOS NAS CÉLULAS MTEC 3.10 COCULTIVADAS COM TIMÓCITOS NAS CONDIÇÕES WT (A) E KO (B)....................................................77

FIGURA 30 PAINEL GERAL DA LOCALIZAÇÃO CROMOSSÔMICA DOS LNCRNAS.......................................78

FIGURA 31 REDE DE INTERAÇÃO DOS MRNAS ALVO DOS LNCRNAS (WT) ...............................................82

FIGURA 32 REDE DE INTERAÇÃO DOS MRNAS ALVO DOS LNCRNAS (KO)..............................................85 


\section{LISTA DE TABELAS}

TABELA 1 GENES CODIFICANTES MAIS PRÓXIMO DO LNCRNA..........................................................78

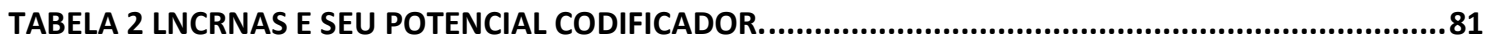

TABELA 3 MRNAS ALVOS DOS LNCRNAS PREDITOS PELA FERRAMENTA LNCTAR..................................83

TABELA 4 MRNAS ALVOS DOS LNCRNAS PREDITOS PELA FERRAMENTA LNCTAR..................................86 


\section{LISTA DE ABREVIATURAS}

aproximadamente

${ }^{\circ} \mathrm{C}$ graus Celsius

3' extremidade 3'

5' extremidade 5'

aa aminoácido

cm2 centímetros quadrados

kDa kilodaltons

$\mathrm{mL} \quad$ mililitro

mM milimolar

pb pares de base

U unidade

V volts

$\mu \mathrm{g} \quad$ micrograma

$\mu \mathrm{l} \quad$ microlitro

$\mu \mathrm{M}$ micromolar 


\section{LISTA DE SIGLAS}

AIRE: Autoimmune regulator

APC: célula apresentadora de antígeno

APECED: (Autoimmune polyendocrinopathy candidiasis ectodermal dystrophy)

APS1: síndrome autoimune poliglandular do tipo 1

CARD: (Caspase recruitment domain): domínio recrutador de caspase

Cas9: (CRISPR associated protein 9), Proteína 9 associada a CRISPR

Cauda poli A: poli adenilação da porção 3' do RNAm

CBP: proteína ligadora de CREB

CCL19: Chemokine (C-C motif) ligand 19

CCL21: Chemokine (C-C motif) ligand 21

CCL25: Chemokine (C-C motif) ligand 25

CD80: T-Lymphocyte Activation Antigen CD80

cDNA: DNA complementar

CPC: calculador de potencial codificador

CpG: sítios CG

CRISPR: (Clustered Regularly Interspaced Short Palindromic Repeats) ou Repetições Palindrômicas Curtas Agrupadas e Regularmente Interespaçadas.

cRNA: RNA complementar

CRP: proteína C reativa

CTEC: célula tímica epitelial cortical

Cy3: cianina 3 verde

DC: Célula dendrítica

DM1: Diabetes Mellitus do tipo 1

DN: Duplo negativo

DNA: ácido desoxirribonucleico

DNA-PK: proteína quinase

DP: Duplo positivo

EpCAM (Epithelial cell adhesion molecule), Molécula de adesão celular epitelial FDR (False Discovery Rate), Taxa de falsa descoberta

gRNA: RNA guia 
H3K4me3: trimetilação da lisina 4 da histona H3

HDR (homology-directed repair), Reparo direcionado por homologia

Indel: Inserções/deleções

kb: kilobase

KO: knockout, nocaute

IncRNA: RNA longo não codificador

MHC: complexo maior de histocompatibilidade

miRNA: MicroRNA

mRNA: RNA mensageiro

mTEC 3.10: linhagem de células tímicas epiteliais medulares murinas (linhagem contínua)

mTEC: célula tímica epitelial medular

NF-kB (Nuclear Factor Kappa B), Fator Nuclear Kappa B

NHEJ: (nonhomologous end joining), Junção de extremidades não homólogas

NLS (Nuclear signal localization), Sinal de Localização Nuclear

N-TEF: fator alongador negativo da transcrição

Oct4: fator de transcrição 4 ligador de octâmero

ORF: matriz de leitura aberta

p53: supressor tumoral p53

PAGE (Polyacrylamide gel electrophoresis), Eletroforese em gel de poliacrilamida

PAM (Protospacer Adjacent Motif), Motivo adjacente ao protoespaçador

PBS: Solução salina tamponada com fosfato

PCR: reação em cadeia de polimerase

PGE: expressão gênica promíscua

PHD (plant homeodomain), Homeodominio de planta

PHD1: domínio tipo dedo de zinco 1

PHD2: domínio tipo dedo de zinco 2

PLP: lipoproteína da mielina

PROVEAN (Protein Variation Effect Analyzer), Analisador de efeitos da variação de proteínas

PTA: antígenos de tecidos periféricos

P-TEFb: fator b alongador positivo da transcrição 
qRT-PCR: reação de polimerização em cadeia quantitativa e em tempo real

RANK (Receptor Activator of Nuclear Factor Kappa B): Receptor ativador de fator nuclear Kappa B

RIN: número de integridade do RNA

RNA pol II: RNA polimerase II

RNA pol III: RNA polimerase III

rRNA: RNA ribossômico

SAND: domínio denominado SP100, AIRE1, nucP41/P75 and DEAF1

SDS: Dodecil sulfato de sódio

SFB: soro fetal bovino

siRNA: pequeno RNA interferente

Sox2: box 2 da região $Y$ determinante do sexo

SP: Simples Positivo

STAT3: sinal transdutor e ativador da transcrição 3

SVM: máquina de suporte de vetores

TCR: receptor de célula $T$

TEC: célula tímica epitelial

TRA: receptor de antígeno tecido-específico

Treg: Célula T reguladora

tRNA: RNA transportador

TSSP: Serina protease tímica especifica

TTATTA: sítio TATA-box

UCSC: Universidade da Califórnia, Santa Cruz

$\mathrm{V}(\mathrm{D}) \mathrm{J}: \mathrm{v}=$ variável, $\mathrm{d}=$ diversidade, $\mathrm{j}=$ junção.

WT: Wild-type 


\section{SUMÁRIO}

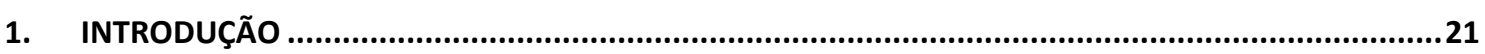

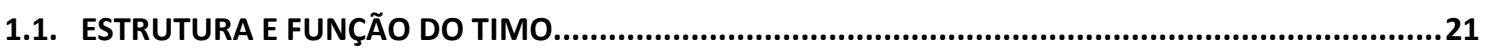

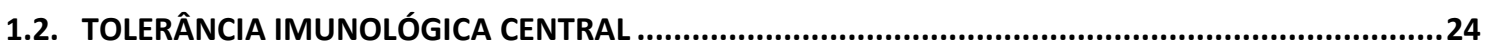

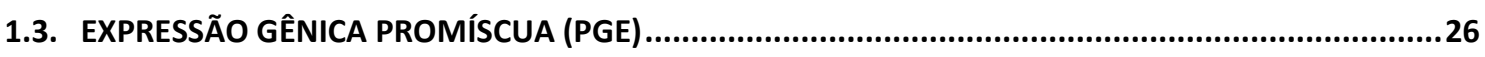

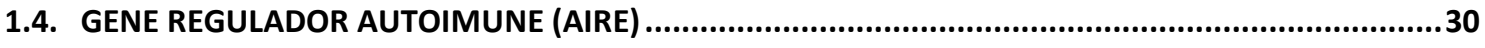

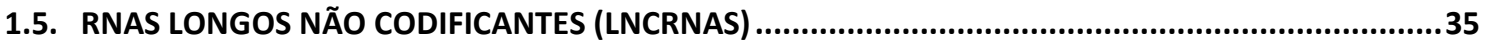

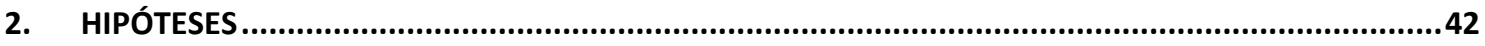

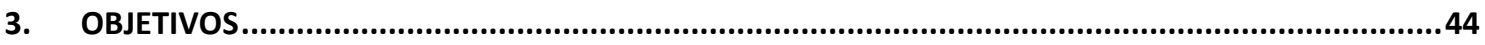

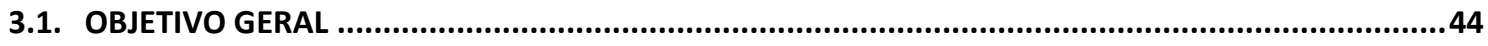

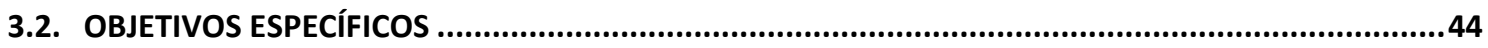

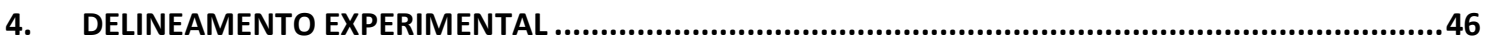

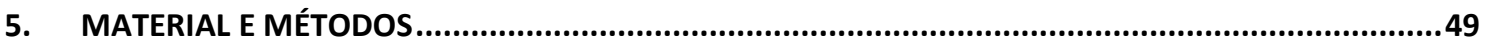

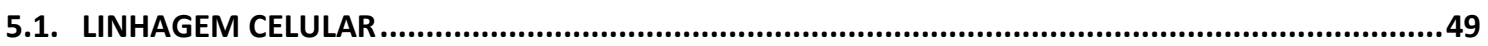

5.1.1. CLONES DE MTEC 3.10 AIRE NOCAUTE OBTIDAS POR CRISPR-CAS9...................................

5.2. ENSAIO DE ADESÃO CELULAR (MTEC-TIMÓCITO) …….............................................................50

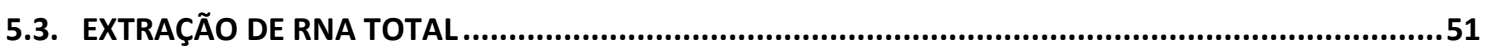

5.4. QUANTIFICAÇÃO E AVALIAÇÃO DO GRAU DE PUREZA DAS PREPARAÇÕES DE RNA TOTAL...........52

5.5. AVALIAÇÃO DA INTEGRIDADE DAS PREPARAÇÕES DE RNA TOTAL .............................................53

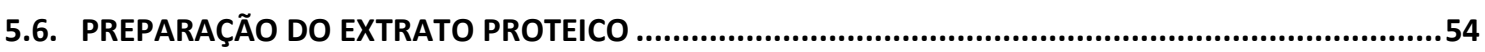

6. ELETROFORESE DE PROTEÍNAS EM GEL DE POLIACRILAMIDA NA PRESENÇA DE SDS (SDS-PAGE) 54

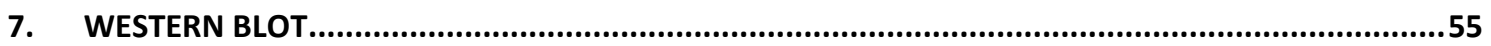

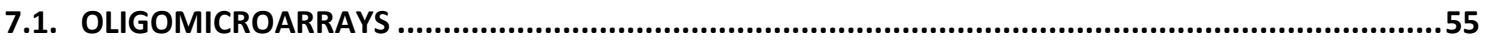

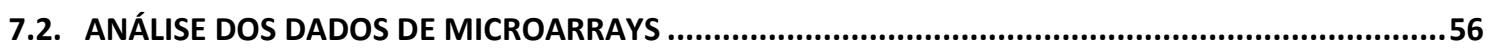

7.3. ANÁLISE ESTATÍSTICA DOS DADOS PARA OBTENÇÃO DOS TRANSCRITOS DIFERENCIALMENTE

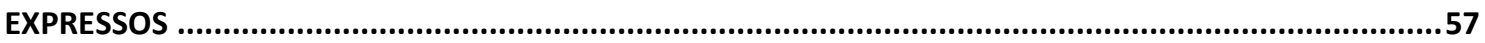

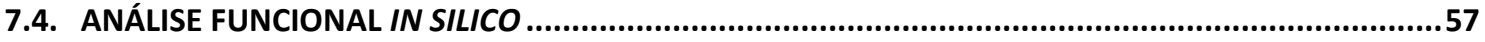

7.5. IDENTIFICAÇÃO DAS SEQUÊNCIAS DOS RNAS LONGOS NÃO CODIFICANTES.................................57

7.6. CLASSIFICAÇÃO DOS RNAS LONGOS NÃO CODIFICADORES …...................................................58

7.7. IDENTIFICAÇÃO E POSICIONAMENTO DOS GENES CODIFICADORES MAIS PRÓXIMOS DOS LNCRNAS

7.8. ANÁLISE DO POTENCIAL CODIFICADOR DOS RNA LONGOS NÃO CODIFICANTES UTILIZANDO O CPC 2

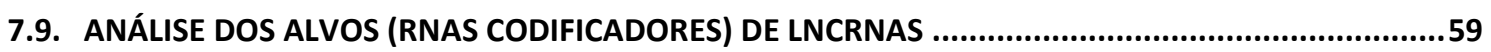

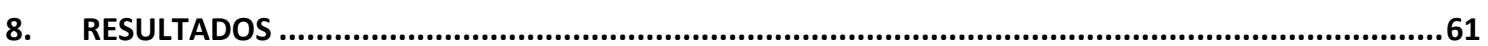

8.1. ANÁLISE POR WESTERN-BLOT DOS EFEITOS DAS MUTAÇÕES DE AIRE ...........................................61 
8.2. ANÁLISE DA ADESÃO ENTRE MTECS-TIMÓCITOS

8.3. ANÁLISE DOS GENES DIFERENCIALMENTE EXPRESSOS EM MTECS WILD-TYPE CO-CULTIVADAS COM TIMÓCITOS. . .63

8.4. LNCRNAS DIFERENCIALMENTE EXPRESSOS EM MTECS KO PARA O GENE AIRE 63

8.5. ANÁLISE DE ENRIQUECIMENTO FUNCIONAL (MTEC 3.10 WT) ................................................66

8.6. ANÁLISE DE MRNA EM CÉLULAS MTEC 3.10E6 AIRE KO .....................................................68

8.7. CARACTERIZAÇÃO DOS LNCRNAS DIFERENCIALMENTE EXPRESSOS EM CÉLULAS MTEC 3.10 WT

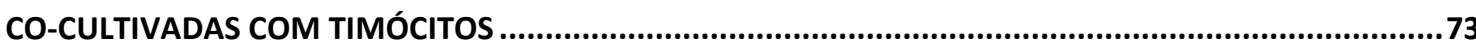

8.8. ANÁLISE DOS LNCRNAS EM CÉLULAS MTEC 3.10E6 AIRE KO CO-CULTIVADAS COM TIMÓCITOS.. 75 8.10. DISTRIBUIÇÃO GENÔMICA DOS LNCRNAS DIFERENCIALMENTE EXPRESSOS ..............................78

8.11. IDENTIFICAÇÃO E POSICIONAMENTO DOS GENES CODIFICADORES MAIS PRÓXIMOS ..................78

8.12. AVALIAÇÃO DO POTENCIAL CODIFICADOR DOS LNCRNAS DIFERENCIALMENTE EXPRESSOS ........81

8.13. REDE DE INTERAÇÃO ENTRE OS LNCRNAS E SEUS ALVOS (MRNAS) EM CÉLULAS MTEC 3.10 (WT) ..... 82

8.14. REDE DE INTERAÇÃO ENTRE LNCRNAS E MRNAS ALVOS EM CÉLULAS MTEC 3.10E6 (AIRE KO) ....85

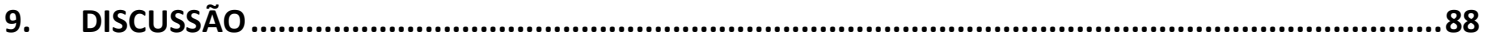

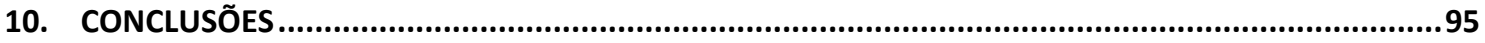

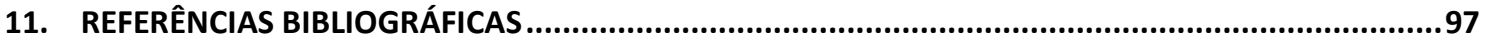

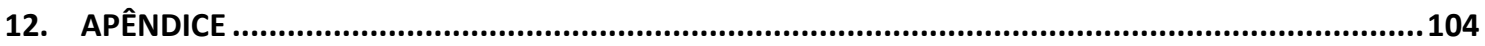

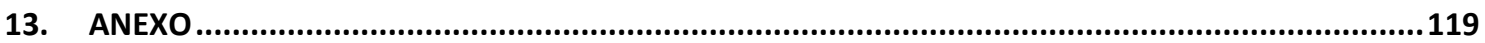


INTRODUÇÃO 


\section{Introdução}

\subsection{Estrutura e função do timo}

O timo é um órgão linfoide primário bilobado essencial para a manutenção da tolerância central por meio da seleção e eliminação de células T autoreativas. Com a forma anatômica piramidal e achatado, localiza-se no mediastino do tórax, em posição dorsal à parte superior do esterno e ventral aos grandes vasos do coração e à traqueia. Iniciando na periferia dos lóbulos com invasão de tecido adiposo, o timo passa um processo conhecido como involução tímica (Figura 1). O timo se desenvolve altamente durante a vida fetal, mas ao longo da vida adulta, com o aumento da idade do indivíduo, sofre um constante processo de involução (TAUB; LONGO, 2005; REZZANI et al., 2014).

Com o envelhecimento, a expressão de Foxn1 no timo e os níveis de esteroides sexuais são essenciais e desempenham papéis críticos na condução ativa para senescência celular e a involução do timo. Como resultado, um declínio exponencial na produção de células $T$ e uma diminuição de respostas imunológicas. (MILLER, 2002; CHINN et al., 2012; GUI et al., 2012; REZZANI et al., 2014).

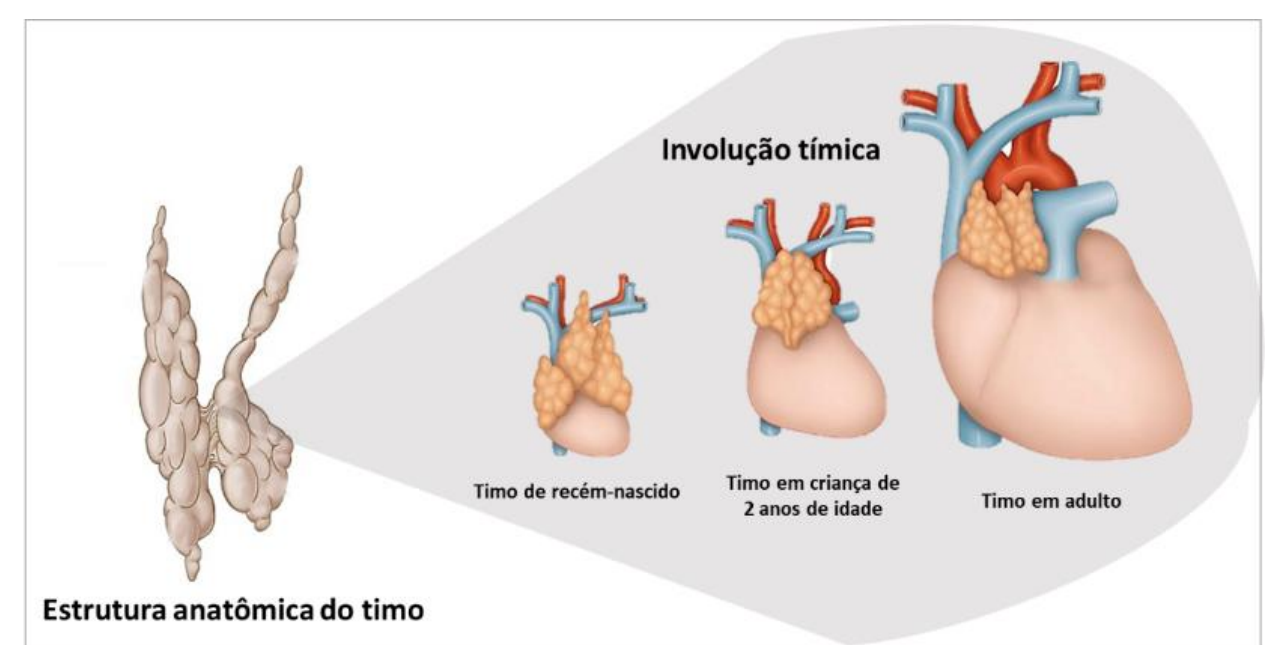

Figura 1 Estrutura anatômica do timo e involução tímica. (Fonte: Adaptado de Musculoskeletal Key, 2018. site: https://musculoskeletalkey.com/). Acesso em 10 de julho de 2018. 
O timo desempenha um papel crucial no estabelecimento do desenvolvimento de um sistema imunológico normal, por meio de uma população diversificada de linfócitos $T$ funcionais em resposta a antígenos não próprios e tolerante a antígenos próprios. Em camundongos recém-nascidos que passam por cirurgia de retirada do timo, timectomia, apresentam uma maior suscetibilidade a infecções intercorrentes associado com respostas imunes debilitadas e tecidos linfoides pouco desenvolvidos (MILLER, 2002).

Advindos de uma origem embrionária de células epiteliais tímicas (TECs) em comum, uma especialização ocorre no último período de gestação que separa o timo em duas principais regiões, o córtex e a medula (TAUB; LONGO, 2005). As células tímicas epiteliais corticais (cTECs) e as células tímicas epiteliais medulares (mTECs) (TAUB; LONGO, 2005; ANDERSON; TAKAHAMA, 2012). O córtex e a medula são formados por um epitélio altamente especializado, caracterizado por uma diferenciação morfológica e funcional e que ao longo do desenvolvimento das células do timo atingem um estado estacionário (KOO; PEPPARD; HATZFELD, 1982; TAUB; LONGO, 2005; REZZANI et al., 2014).

O microambiente que compõem o timo, conhecido como estroma tímico, tem como característica uma rede de diferentes células como fibroblastos, células mesenquimais não fibroblásticas, células de tecido conjuntivo, endoteliais, células dendríticas (DCs), macrófagos, células hematopoiéticas CD45+ e células epiteliais formando a matriz na qual as células progenitoras linfoides T (timócitos) se desenvolvem. (REZZANI et al., 2014). Separado por duas regiões bem definidas, cada lóbulo do timo tem uma parte periférica, a região cortical, e uma parte central, mais clara, a região medular (Figura 2) (TAUB; LONGO, 2005; REZZANI et al., 2014). Essas estruturas básicas, tipos celulares e organização linfocitária na região cortical e medular, apresentam características evolutivas preservadas em diferentes espécies de vertebrados (Figura 2) (REZZANI et al., 2014). 


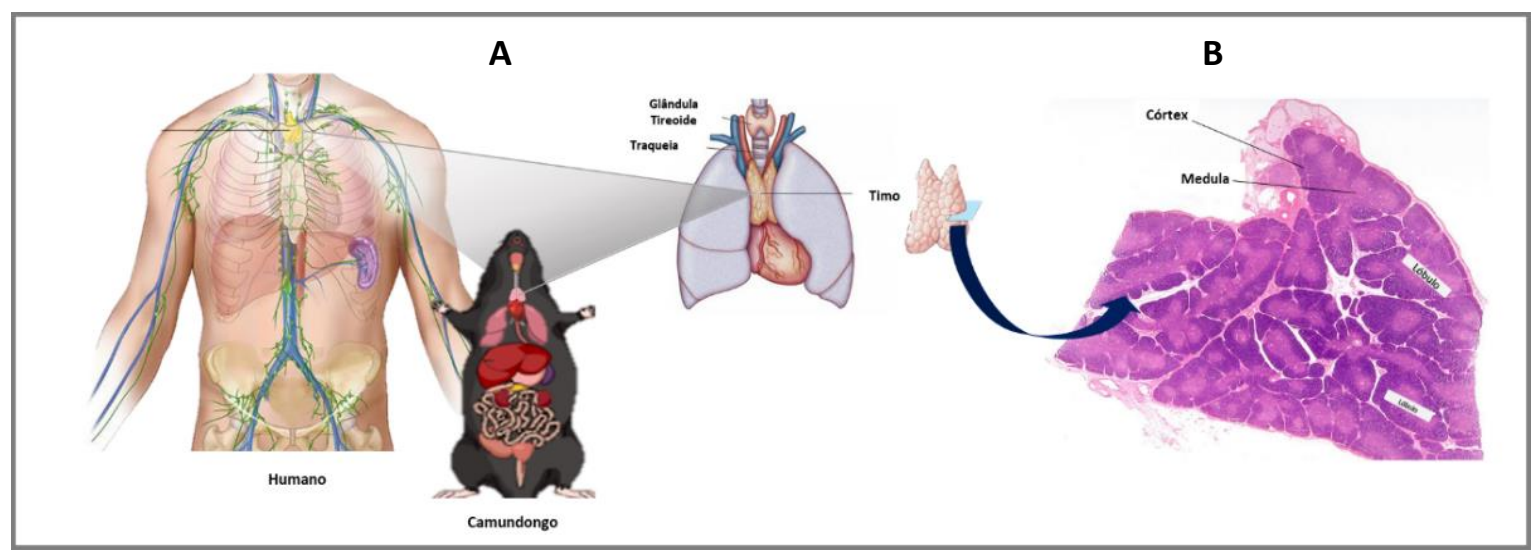

Figura 2 Localização anatômica do timo. A) Visualização esquemática da posição anatômica do timo em humanos e camundongos. B) Corte histológico longitudinal evidenciando os lóbulos tímicos e a região da medula (tom mais claro) e região cortical (tom mais escuro) (Fonte: Adaptado de HSC Boards Wiki, 2018).

As cTECs contribuem na maturação dos timócitos e na seleção positiva de células $T$, processo que consiste na interação das cTECs com os timócitos e reconhecimento do complexo principal de histocompatibilidade (MHC) próprio. Assim, as células que passam com sucesso por essa seleção amadurecem em células T duplo positivas (DP) $\mathrm{CD}^{+} \mathrm{CD}^{+}$e se acumulam no córtex (GOLDMAN et al., 2005; PASSOS et al., 2018). Enquanto, as mTECs são essenciais para 0 estabelecimento da auto tolerância com a expressão do gene regulador autoimune (Aire) e no desenvolvimento de células $T$ por meio da expressão de apresentação de numerosos antígenos próprios, pela indução da deleção clonal, eliminando as células $T$ auto reativas e induzindo a diferenciação e geração de células T reguladoras (Treg) (Figura 3) (HOGQUIST; BALDWIN; JAMESON, 2005; NISHIJIMA et al., 2018). 


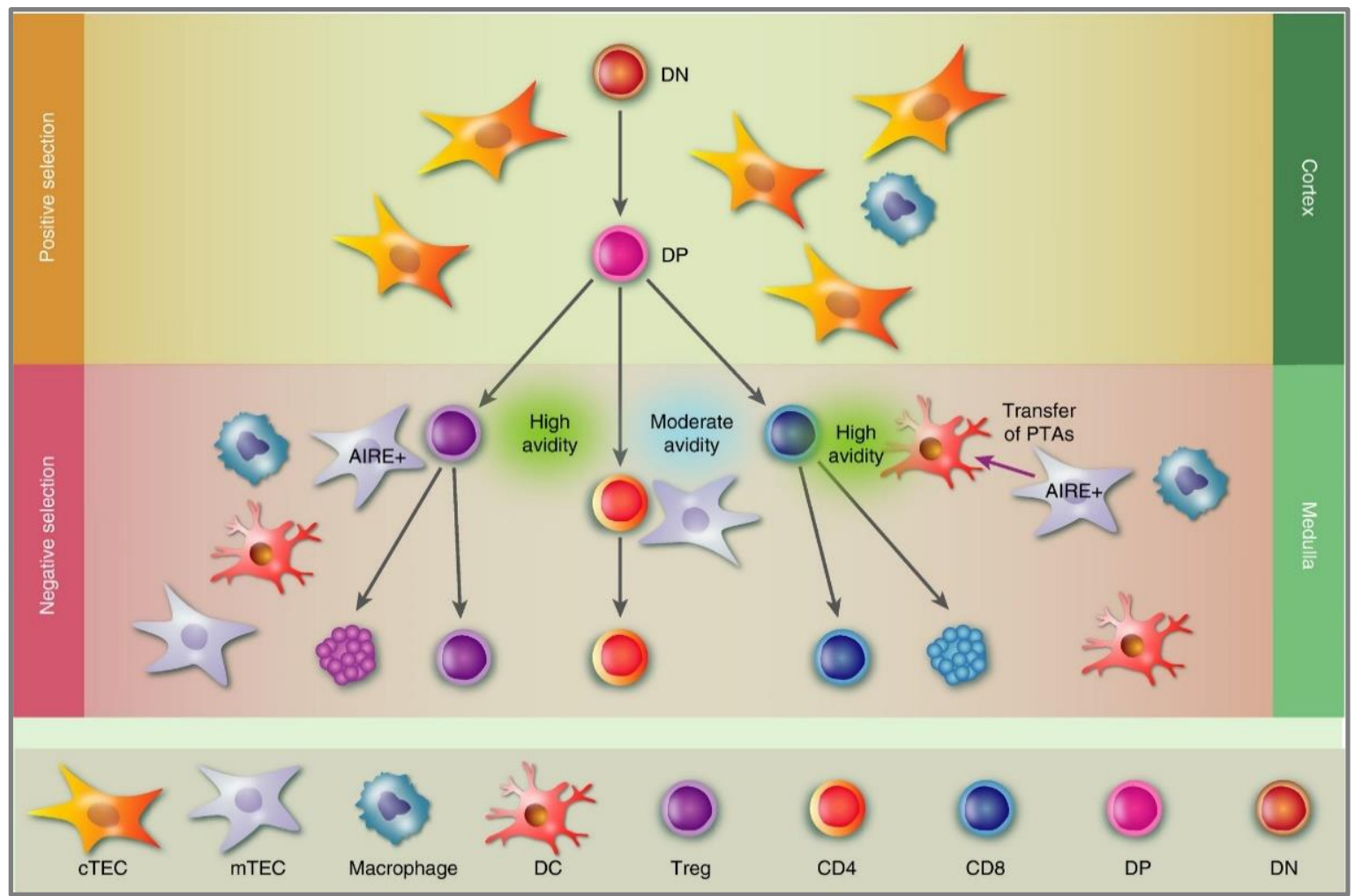

Figura 3 Mecanismos de seleção negativa e positiva no ambiente tímico. Diferentes tipos de células formam uma densa rede favorável para a maturação das células $T$ imaturas. A seleção negativa ocorre na região medular do timo. Os timócitos duplo positivos (DP: C4+ CD8+) migram do córtex para a medula, onde interagem com as células medulares tímicas (mTECs) e células apresentadoras de antígenos (APCs). Interação de alta avidez dos receptores de células T com os TRAs apresentados pelas moléculas de MHC induzem a deleção de timócitos por apoptose ou diferenciação em células T-reguladoras (Treg). As mTECs Aire+ apresentam auto antígenos em sua superfície e podem também transferir TRAs para células dendríticas (Fonte: Passos et al, 2018).

\subsection{Tolerância Imunológica Central}

O microambiente do estroma tímico induz os timócitos ao desenvolvimento, estabelece o repertorio de receptores de células $T$ (TCRs), que são receptores de antígeno-específicos essenciais para a resposta imune, e participa da eliminação de células $T$ autorreativas, por meio dos processos de seleção positiva e seleção negativa (ANDERSON; TAKAHAMA, 2012; LAU et al., 2018).

Advindos da medula óssea, os precursores de timócitos não expressam TCR ou os correceptores $\mathrm{CD}^{+}{ }^{+}$e $\mathrm{CD} 8^{+}$, e migram para o córtex do timo, onde os 
TCRs são gerados por rearranjo de DNA e selecionados positivamente por meio de sua capacidade de interação com Moléculas do Complexo principal de Histocompatibilidade (MHC) (KLEIN et al., 2014; TAKABA; TAKAYANAGI, 2017). Inicialmente serão expressos TCRs yठ e a $\beta$ para posteriormente as células $\mathrm{T} \alpha \beta$ desenvolverem em células $\mathrm{T} C D 4^{+}$restritas $\mathrm{MHC}$ de classe II, ou $\mathrm{CD}^{+}$restritas ao MHC de classe I. Moléculas de quimiocinas (CCL, CCL25, $\mathrm{CXCL}$ ), moléculas de adesão como a P-selectina e citocinas como interleucina (IL)-7, são essenciais no processo maturação dos timócitos (TAKABA; TAKAYANAGI, 2017).

A seleção positiva ocorre no córtex do timo promovendo a diferenciação dos timócitos em células T CD4+ ou CD8+ (STARR; JAMESON; HOGQUIST, 2003; ANDERSON; TAKAHAMA, 2012). Essa diferenciação ocorre quando as células T CD4 e CD8 reconhecem, por meio da apresentação de cTECs, o complexo formado pelo peptídeo e pela molécula de MHC (ANDERSON; TAKAHAMA, 2012; TAKABA; TAKAYANAGI, 2017). De acordo com a afinidade com as moléculas de $\mathrm{MHC}$ (classe II ou I) se diferenciam em células $\mathrm{T} \mathrm{CD}^{+} \mathrm{e}$ CD8 ${ }^{+}$respectivamente e induzem a expressão do receptor de quimiocina CCR7 e de várias citocinas da família do TNF, incluindo RANKL (receptor ativador do fator nuclear $\kappa \beta$ /ligante) que se liga ao receptor RANK. Esse receptor para RANKL, o RANK, é expresso em mTECs, bem como, os ligantes do CCR7, CCL19 e CCL21, também são altamente expressos induzindo, além do crescimento e maturação da medula tímica (RANKL / RANK / CD40L), a migração dessas células em direção a medula do timo (KUROBE et al., 2006; FÖRSTER; DAVALOS-MISSLITZ; ROT, 2008; TAKABA; TAKAYANAGI, 2017).

$O$ processo de seleção negativa ocorre na medula do timo, as células $T$ selecionadas positivamente no córtex migram para a medula e são expostos a um conjunto diversificado de auto antígenos apresentados por mTECs e DCs. Uma interação que normalmente culmina na deleção clonal de células $T$ autorreativas (STARR; JAMESON; HOGQUIST, 2003).

Dada a expressão de proteínas (antígenos) em tecidos específicos do corpo, torna-se fundamental que as mTECs expressem um grande número de antígenos restritos a tecidos (TRAs) para o controle da autoimunidade. Certos TRAs são transferidos de mTECs para células dendríticas na medula, enfatizando ainda mais a importância da produção TRAs por mTECs. Quase 
todas as células $\mathrm{T}$ que reconhecem complexos auto-antígeno-MHC com certa avidez são deletadas por mTECs e células dendríticas tímicas (STARR; JAMESON; HOGQUIST, 2003; KLEIN et al., 2014; TAKABA; TAKAYANAGI, 2017).

Na medula tímica as células $T$ em desenvolvimento circulam em torno de 4 a 5 dias e quando essas células expressam um TCR funcional sem reatividade significativa aos auto antígenos, migram para os órgãos linfoides secundários, como os linfonodos e o baço e são distribuídos para atuarem por todo o corpo (KLEIN et al., 2014).

\subsection{Expressão gênica promíscua (PGE)}

Para o bom funcionamento do sistema imunológico adaptativo, torna-se necessário reconhecer e distinguir moléculas que são próprias e não próprias do organismo. A expressão de antígenos que são predominantemente expressos em tecidos específicos (TRAs) no timo se intitula como expressão genica promíscua (PGE) (DERBINSKI et al., 2001, 2016; GOTTER et al., 2004).

Como característica peculiar do timo, sua população de células epiteliais medulares (mTECs) expressam na sua superfície mais de 19.000 genes que representam virtualmente uma gama diversificada de antígenos específicos dos próprios tecidos do corpo e pode induzir a tolerância a uma ampla gama de TRAs o que as difere de outras células epiteliais comuns (Figura 3). Essa expressão ectópica por mTEC, que representa aproximadamente $60 \%$ do genoma total do camundongo, tem um relevante papel na tolerância e autoimunidade das células T, dando luz a PGE (DERBINSKI et al., 2001, 2005, 2016; SANSOM et al., 2014).

A indução da PGE tem sido associada essencialmente com o gene regulador autoimune (Aire), um fator de transcrição não clássico que induz a expressão de TRAs dependentes de Aire em mTECs. No entanto, existem uma grande parcela de genes de TRAs que são induzidos na ausência de Aire (DERBINSKI et al., 2005), mostrando que existem outros reguladores transcricionais sejam funcionais na indução de auto-antígenos em mTECs (Figura 4) (KYEWSKI; DERBINSKI, 2004; DERBINSKI et al., 2005). 
Um estudo recente, baseado na ampla gama de TRAs que são expressos em mTECs Knockout (KO) para Aire, sugeriu a possibilidade de que outros fatores de transcrição ou moléculas regulatórias, poderiam estar envolvidas na regulação e expressão de TRAs em mTECs. A significativa expressão do gene Fezf2 no timo de camundongos e humanos e na ampla gama de TRAs que continuavam a ser expressos em mTECs Knockout para Aire, sugeriu que esse fator de transcrição também poderia regular a expressão de TRAs em mTECs.

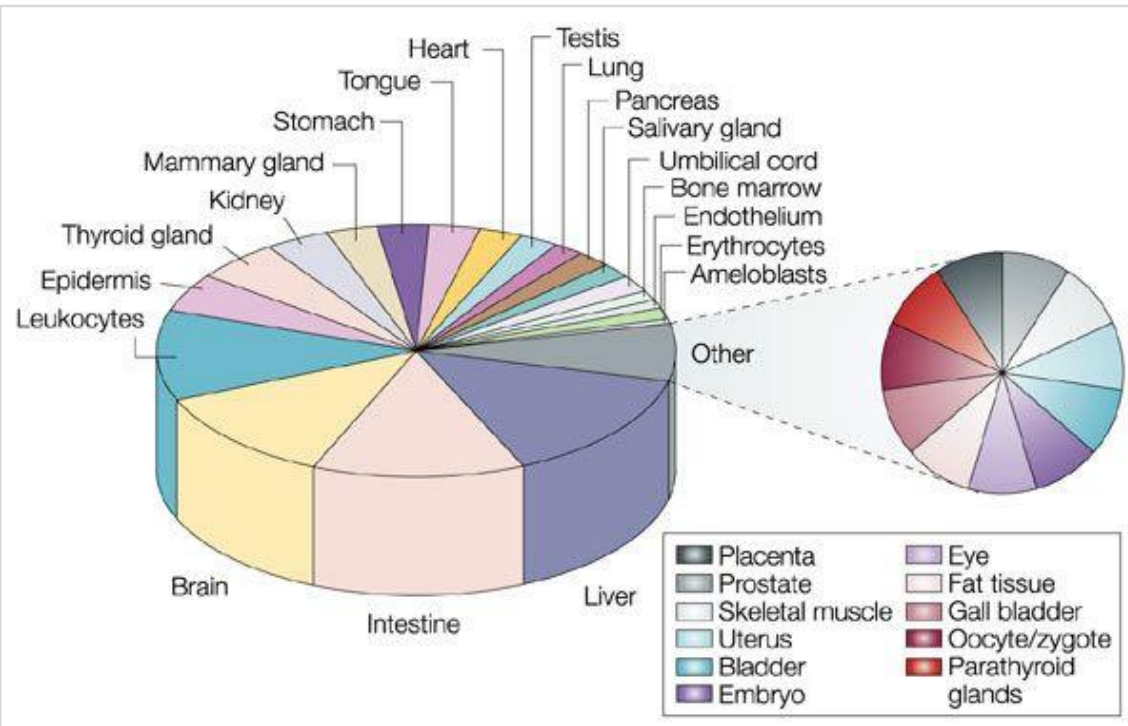

Nature Reviews | Immunology

Figura 4 Diversidade de antígenos próprios expressos em células mTECs. Potencial de expressão de milhares de TRAs, representando virtualmente todos os tecidos do corpo na superfície das mTECs. (Fonte: Kyewski \& Derbinski, 2004)

Embora o gene Aire e Fezf2 sejam expressos em mTECs, ambos são regulados por vias de sinalização distintas e promovem a expressão de diferentes classes de proteínas. Assim, demonstrado em estudo que dois fatores independentes, Fezf2 e Aire, permitem a expressão de TRAs no timo para garantir a tolerância imunológica (KLEIN, 2015; TAKABA et al., 2015) (Figura 5).

A expressão de Aire se limita principalmente no timo, e atua como um fator de transcrição não clássico, pois não se liga diretamente a regiões especificas do DNA para a transcrição de TRAs e regula a expressão ectópica de mais de 3200 genes em mTECs que correspondem aproximadamente 28,9\% do total de TRAs. A interação da proteína AIRE se dá por meio de um complexo transcricional de fatores nucleares, como histona $\mathrm{H} 3$ e o recrutamento 
preferencial de Aire para sítios de repressão seletiva por meio do complexo de proteínas ATF7ip-MBD1, para liberar, "empurrando" as moléculas de RNA Pol II que se encontram em repouso funcional nas regiões promotoras do genes (GIRAUD et al., 2012; WATERFIELD et al., 2014).

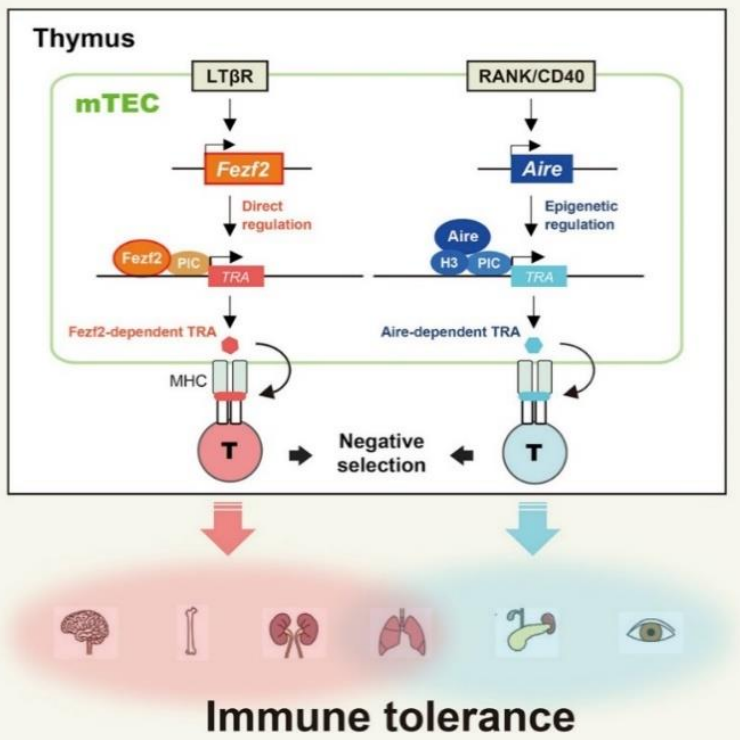

Figura 5 Aire e Fezf2 na expressão de TRAs. Expressão promíscua de antígenos restritos ao tecido (TRAs) em mTECs via Aire e via fator de transcrição Fezf2. Uma regulação por sinalizações distintas e expressão de diferentes genes de TRAs em mTECs, garantindo a tolerância central imunológica (Fonte: Takaba et al., 2015).

Em contraste o gene Fezf2, tem sua expressão funcional que vai além das mTECs no timo, desempenhando um papel, por exemplo, no sistema nervoso central. Um estudo publicado por Takaba e colaboradores (2015), mostrou que Fezf2 regula aproximadamente $21,1 \%$ de TRAs não dependentes de Aire, por meio de um domínio de ligação direta ao DNA. Juntos, Aire e Fezf2 compartilham em torno de $12 \%$ da indução da expressão dos mesmos TRAs e um total de $62,3 \%$ de TRAs dependentes (TAKABA et al., 2015) (Figura 6). 


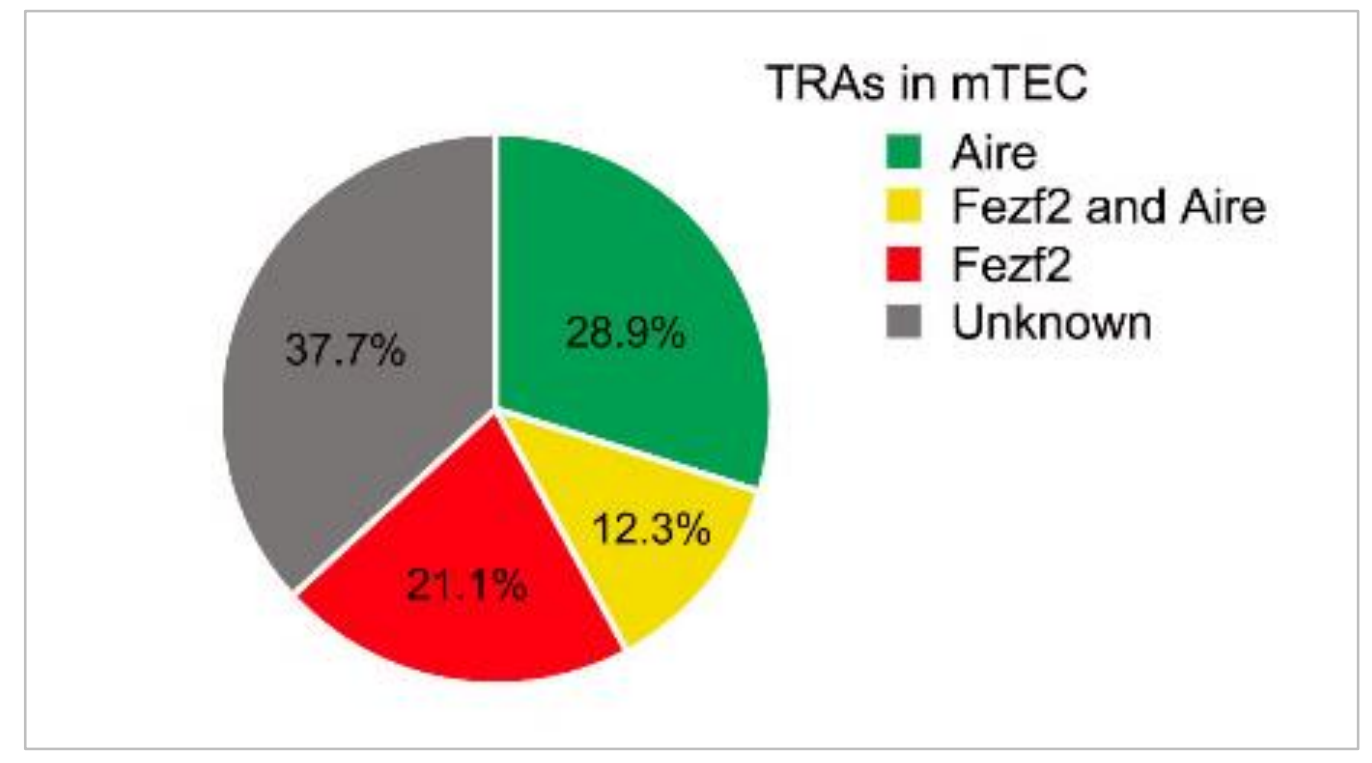

Figura 6 Gráfico representando a proporção de TRAs em mTECs regulados pelos genes Aire e Fezf2. (Fonte: Takaba et. al., 2015).

O estágio de maturação das mTECs influencia diretamente na diversidade de TRAs apresentados na superfície da célula. As mTECs em um estado de maturação mais avançado e que apresentam alta expressão de MHCII, CD80 e AIRE (CD80 high MHCII highAIRE+) são mais aptas a PGE (DERBINSKI et al., 2005). Contudo, embora toda a população de mTECs maduras estejam aptas a expressar quase todos TRAs, cada TRA só é expresso por uma pequena fração (1 -3\%) das mTECs em determinados momentos (KLEIN et al., 2014).

A falha em estabelecer ou manter a auto tolerância pode levar a autoimunidade e gerar quadros de doenças autoimunes clássicas, como artrite reumatoide, diabetes tipo 1 e esclerose múltipla. Os mecanismos de regulação molecular da PGE ainda permanecem parcialmente incompreendidos. 


\subsection{Gene regulador autoimune (Aire)}

O gene regulador autoimune (Aire), tem $11.9 \mathrm{~kb}$ de comprimento, localizase no cromossomo $21 \mathrm{q} 22.3$ em humanos, contém 14 exons que codifica para um mRNA de 1635 nucleotídeos, que por sua vez codifica uma proteína de 545 aminoácidos. No camundongo (Mus musculos) localiza-se no cromossomo 10 na posição de citobanda $39.72 \mathrm{cM}$, tem 13kb de comprimento e codifica para um mRNA de 14 exons que codifica para uma proteína de 545 resíduos de aminoácidos com aproximadamente $77 \%$ de identidade com o genoma humano (Figura 7) (BLECHSCHMIDT et al., 1999; MATHIS; BENOIST, 2007).

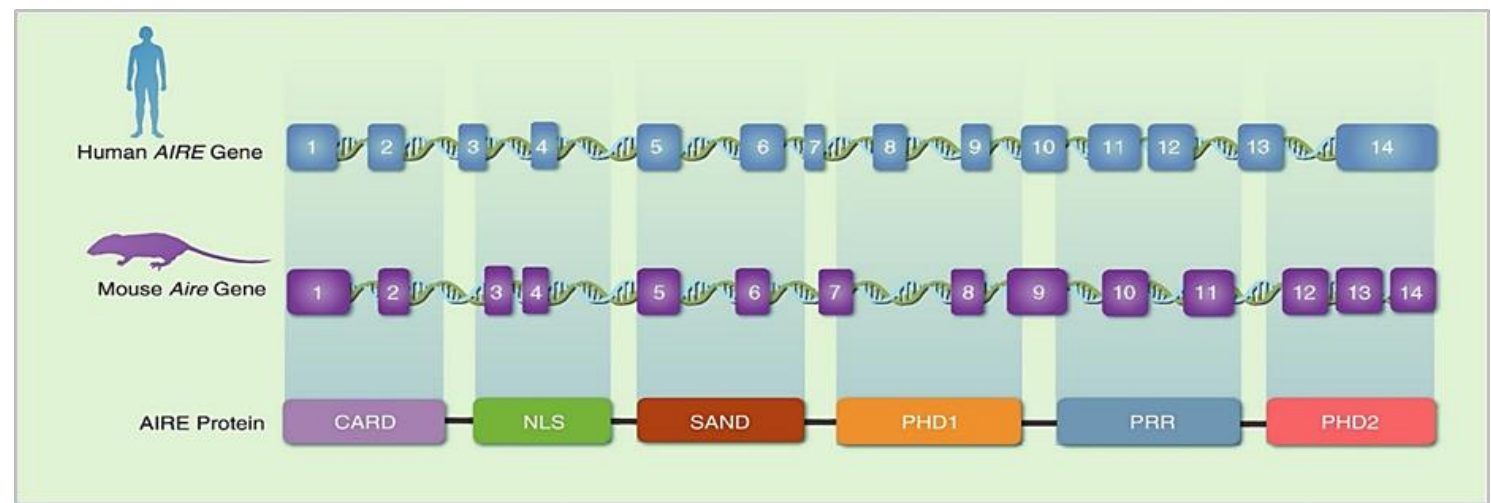

Figura 7 Regiões codificantes do gene Aire em humanos e camundongos e seus respectivos domínios (Fonte: Passos et al, 2018)

Embora seja preferencialmente expresso no timo e em células mTEC, a expressão de Aire já foi observada em vários tecidos e células, como pâncreas, córtex supra renal e na periferia em monócitos e células dendríticas (FAN et al., 2009; PALMA et al., 2013). Os TRAs induzidos por Aire são encontrados exclusivamente em mTEChigh (mTECs maduras Aire ${ }^{+} \mathrm{MHCll}^{\text {high }} \mathrm{CD} 80^{\text {high }}$ ), enquanto os TRAs independentes do AIRE são detectados não apenas em mTEChigh, mas também em CTEC e mTEC ${ }^{\text {low }}$ (Aire- $\mathrm{MHCII}^{-1 / 0} \mathrm{CD} 80^{-1 / 0}$ ), classificação baseada de acordo na expressão baixa ou alta de moléculas de CD80 e MHC de classe II (DERBINSKI et al., 2001; ROSSI et al., 2007; ULYANCHENKO et al., 2016). Essa expressão de TRAs pode ser considerada não aleatória e simultaneamente "estocástica" e "ordenada". Aire induz a expressão estocástica de TRAs individualmente em mTECs, uma pequena quantidade (1-3\%) do número total de mTECs em um determinado momento 
expressa um conjunto de TRAs específicos e a expressão ordenada refere-se a uma maior probabilidade de que um conjunto de genes de

TRAs frequentemente será co-expresso individualmente em uma determinada mTEC (DERBINSKI et al., 2008; PINTO et al., 2013; BRENNECKE et al., 2015; MEREDITH et al., 2015; ANDERSON; SU, 2016; SU et al., 2017).

A expressão de TRAs se dá por meio da interação da proteína AIRE em parceria com outras proteínas, funcionalmente para: processos transcricionais de ligação à cromatina e liberação da RNA polimerase II (RNA pol II) ancorada, alongamento na fita de RNA, processamento do pré-mRNA, busca e reconhecimento de genes de TRAs, bem como na auto regulação de AIRE e no transporte nuclear da proteína. Essa associação do complexo proteico, leva a ativação da PGE quando recrutadas para os locais gênicos de início de transcrição (TSS), local onde a RNA pol Il está ancorada (ABRAMSON et al., 2010; ABRAMSON; GOLDFARB, 2016).

Para que ocorra a transcrição, modificações de histonas e desacetilação mediada por SIRT-1 permitem que TOP2a induza a mudanças epigenéticas e relaxamento da cromatina nas regiões de início de transcrição permitindo o recrutamento do complexo pTEFb / BRD4, liberando o RNA Pol II e o subsequente alongamento da transcrição (ANDERSON; SU, 2016; SU et al., 2017).

Como dito anteriormente, a proteína AIRE impulsiona a RNA Pol II que já deu início a uma pequena região de transcrição e permanece ancorada na cromatina dando início ao alongamento da transcrição promíscua de espécies de RNAs codificantes e RNAs não codificantes (Figura 8). Como demonstrado por nosso grupo, a redução parcial do gene Aire levou a mudança na expressão de pequenas moléculas de microRNAs em mTECs e existem miRNAs que atuam no controle pós-transcricional de Aire (Figura 8) (MACEDO et al., 2013; OLIVEIRA et al., 2016). 


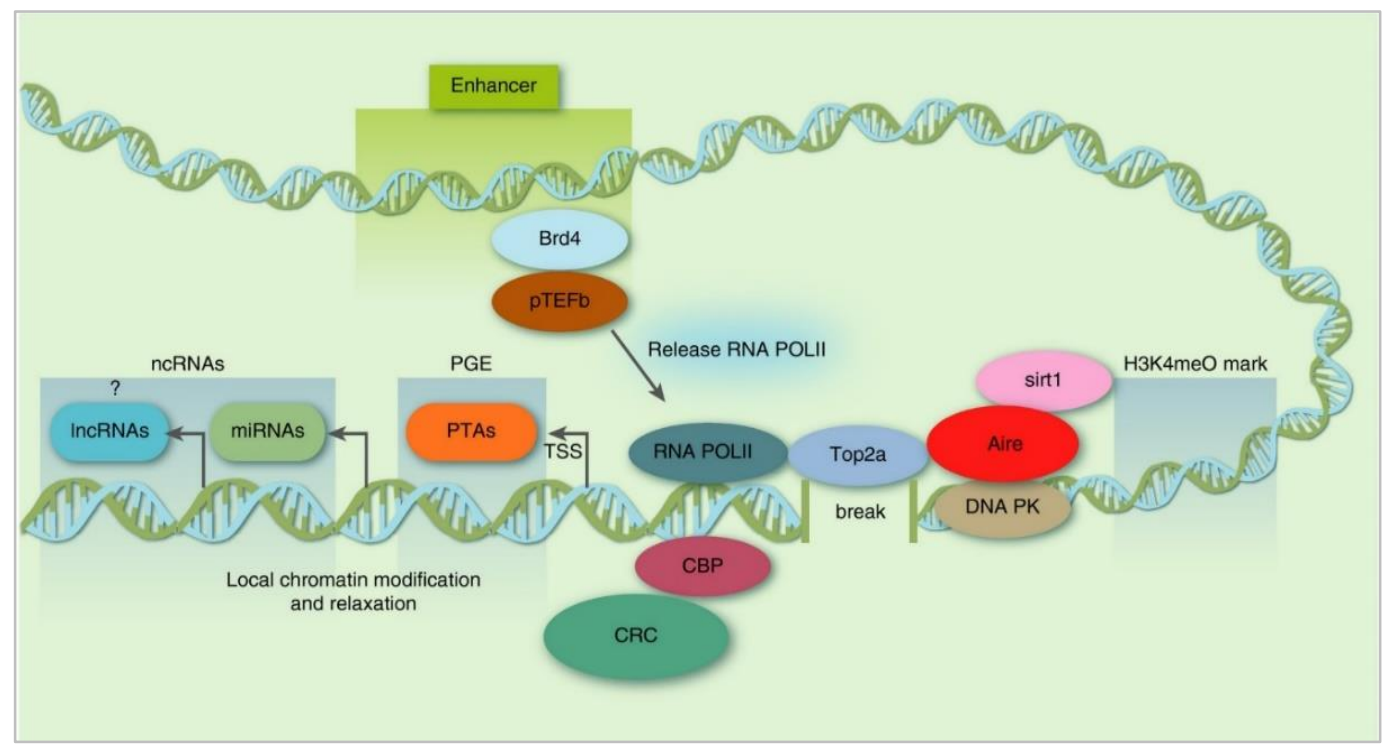

Figura 8 Indução da PGE via Aire em associação com outras proteínas. Associação de AIRE com outras proteínas funcionais e sua ligação na cromatina para a transcrição promíscua de TRAs/PTAs. Além da expressão de TRAs, a indução promovida para ação da RNA POL II leva a expressão de moléculas de RNAs não codificantes (Fonte: Passos et al, 2018).

Mutações ao longo do gene Aire e variações genéticas que afetam diretamente sua atividade levam a distúrbios na homeostase imunológica ou doenças autoimunes em humanos, como à síndrome poliglandular autoimune tipo 1 (APS-1, também conhecida como APECED), uma doença autossômica recessiva rara e clinicamente definida pela presença dos achados patognomônicos como, hipoparatireoidismo candidíase mucocutânea crônica e insuficiência adrenal primária (Figura 9) (BRUSERUD et al., 2016). 


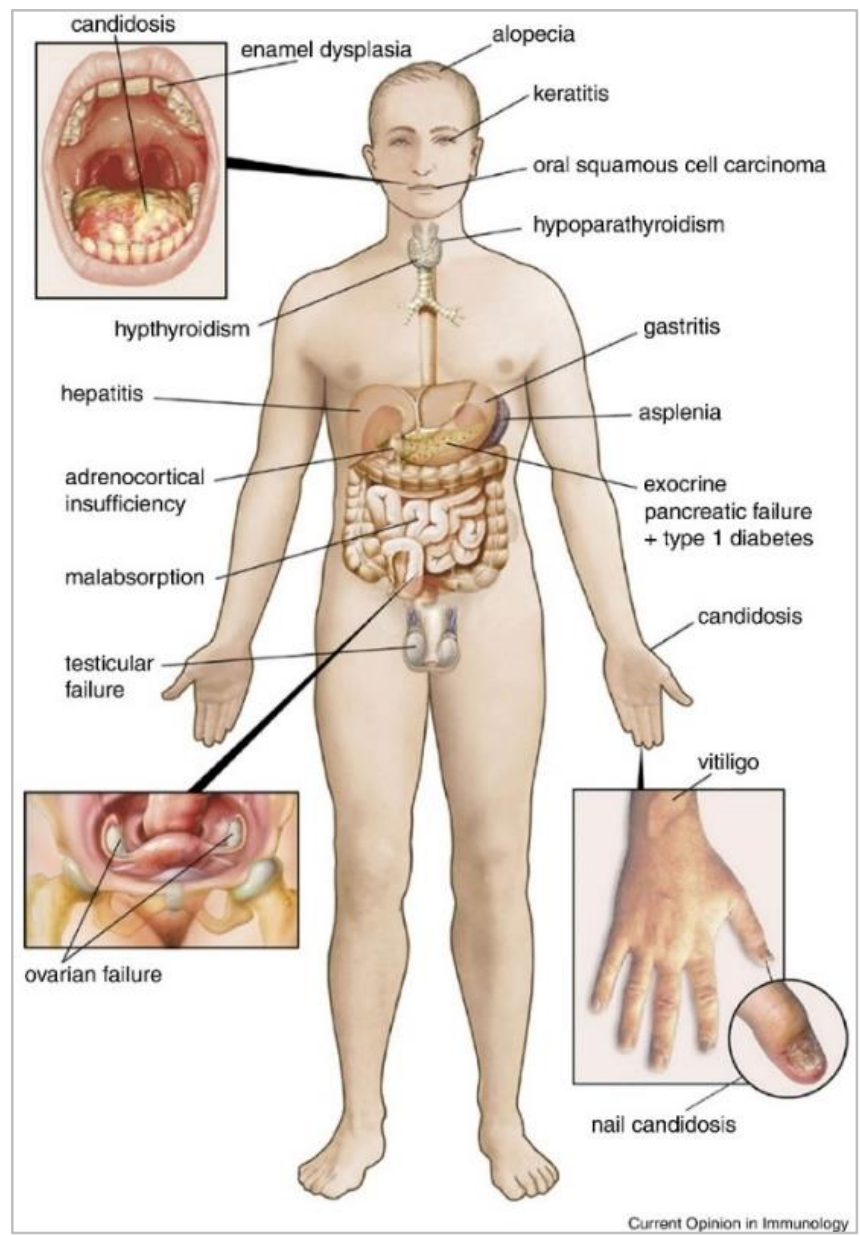

Figura 9 Descrição dos principais sinais clínicos apresentados no estabelecimento da doença em pacientes com APECED. Quadro clínico altamente variável, com característica de inflamação generalizada das mucosas. Principais componentes se destacam com a presença de candidíase mucocutânea crônica, insuficiência adrenal primária e hipoparatireoidismo (Fonte: Bruserud, Oftedal Wolff, \& Husebye, 2016)

Em humanos, mutações em Aire tem levado a uma maior compreensão dos domínios que o formam. A mutação mais comum no mundo, encontrada na Finlândia e países do Leste Europeu, denominada como mutação principal finlandesa p.R257*, se localiza em um dos quatros principais domínios de Aire conhecido como domínio SAND (Figura 10) (BRUSERUD et al., 2016). 


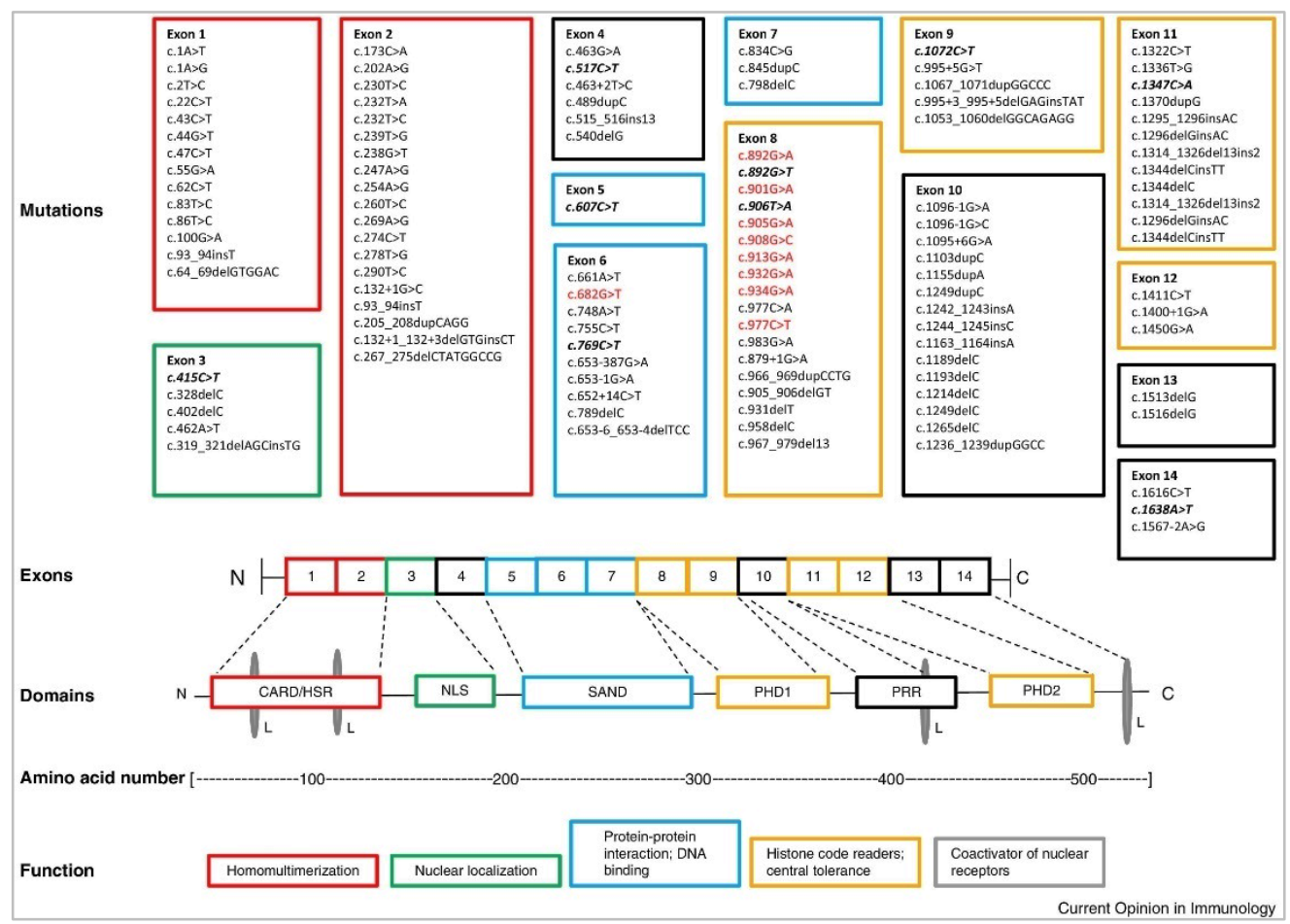

Figura 10 Mutações descritas nos domínios funcionais da proteína AIRE. Distribuição das mais de 100 mutações que já foram descritas ao longo dos subdomínios funcionais de AIRE (Fonte: Bruserud, Oftedal Wolff, \& Husebye, 2016).

A saber, Aire se estrutura em 4 domínios funcionais conhecidos como CARD, SAND, NLS e PHD. O domínio CARD (domínio de recrutamento de caspases) é essencial para a oligomultimerização de AIRE, portanto alterações nesse domínio podem levar ao comprometimento da multimerização do complexo AIRE. O domínio SAND (nomes anteriores SP100, AlRE1, NucP41 / P75 e ㅌEAF1) está envolvido na regulação transcricional associado à cromatina por meio da ligação proteína-proteína e a ligação ao DNA. O domínio NLS (Sinal de Localização Nuclear) medeia a migração da proteína AIRE do citoplasma para o núcleo. E os domínios PhD1-2 (homeodomínio de plantas 1-2) envolvidos na leitura dos códigos de histonas e no remodelamento da cromatina(ABRAMSON et al., 2010; BRUSERUD et al., 2016; ABBOTT et al., 2018)

A função de Aire vai além da expressão de TRAs em mTECs, dos mais de 3000 genes que induzidos por Aire em mTECs apenas 25\% são classificados como TRAs. Adicionalmente Aire está envolvido, por exemplo, no desenvolvimento de células Treg, modulação de quimiocinas, diferenciação de mTECs. A deficiência de Aire impede a expressão de marcadores de superfície 
como queratina 6 (K6), K10, involcrina e SPINK5 para maturação final das mTECs e interação entre mTECs e timócitos no processo de adesão celular. Uma rede celular, para a maturação dos timócitos, composta por proteínas de matriz extracelular (ECM) como lamininas, integrinas, colágenos e fibronectinas, bem como moléculas solúveis como hormônios, citocinas, quimiocinas e fatores de crescimento (MENDES-DA-CRUZ et al., 2012; SAVINO et al., 2015).

Em um estudo realizado em nosso laboratório demonstrou que a inibição parcial do gene Aire nas mTECs 3.10 induzida por siRNA, resultou em um decréscimo da capacidade de adesão entre mTEC-timócito (PEZZI et al., 2016), reafirmando a influência do gene Aire no ambiente da matriz celular tímica, onde há a interação entre as células $T$ imaturas em desenvolvimento com 0 microambiente tímico.

\subsection{RNAs longos não codificantes (IncRNAs)}

As moléculas de RNAs longos não codificantes (IncRNAs) representam uma classe de RNAs classificados convencionalmente em tamanho >200 nucleotídeos. Estima-se que, em humanos, o número de transcritos de IncRNAs podem variar de 5.000 a 15.000 , entretanto considera-se um valor subestimado tendo em vista a pouca sobreposição entre os diferentes bancos de dados de IncRNAs (ZHENG et al., 2007; PAYRE; DESPLAN, 2016; CHOI; KIM; NAM, 2018).

A expressão dos IncRNAs é considerada tecido específica, uma especificidade que pode ter sido evolutivamente conservada ao longo do tempo, e o seu local de expressão poderá indicar sua função específica naquele tecido. Como principais características definidas dos IncRNAs, se destacam a ausência de matriz de leitura aberta (do inglês Open Read Frame - ORFs), capacidade de regulação cis ou trans e presença ou não de cauda poli A (PONTING; OLIVER; REIK, 2009; RINN; CHANG, 2012; MERCER; MATTICK, 2013).

Contudo, os componentes de RNA codificante e de RNA não codificante, presentes nessas moléculas, levam a um paradoxo de uma possível bifuncionalidade o que dificulta uma classificação definida nos bancos de dados (ZHENG et al., 2007; MERCER; MATTICK, 2013). 
Os IncRNAs podem regular em múltiplos níveis na via de controle da expressão gênica, como por exemplo na regulação pós-transcricional por meio do controle de processos da síntese proteica, maturação e transporte de RNAs, no silenciamento gênico transcricional e via de regulação da estrutura da cromatina (KUNG; COLOGNORI; LEE, 2013; MERCER; MATTICK, 2013).

As diversas estruturas desses RNAs envolvem mecanismos que levam a diferentes resultados regulatórios, cujas funções ainda estão caminhando para serem mais bem elucidadas. Algumas funções dos IncRNAs tem sido associadas a regulação da modificação da cromatina silenciando vários genes por meio da interação com DNA e/ou proteínas modificadoras da cromatina (RINN; CHANG, 2012; MERCER; MATTICK, 2013).

Quanto a forma estrutural, os IncRNAs não têm um arquétipo molecular único. Podem funcionar por meio de domínios estruturais, que possibilitam a interação com o DNA ou RNA por meio do emparelhamento de bases de ácidos nucléicos ou com proteínas por meio de estruturas de RNA de ordem superior. Com a possibilidade de transcrever o próprio IncRNA e exercer efeitos reguladores de genes por meio de mudanças na acessibilidade da cromatina ou até mesmo levar o fator de transcrição aos promotores do gene-alvo (Figura 11) (LIANG; BLOOM; SMOLKE, 2011; ZHANG; TAO; LIAO, 2017).

Uma grande parte dos IncRNAs que já foram encontrados, modulam a transcrição por ligação no DNA alvo em regiões específicas da cromatina. Outras classes de IncRNAs atuam por meio da interação RNA-RNA, como por exemplo, servem de 'esponjas' de miRNAs, mecanismo pelo qual o IncRNA serve de ligação com os miRNAs o que impede a ligação desse último com seu mRNA alvo funcional (Figura 12). Outra interação funcional dos IncRNAs é a ligação com proteínas, recrutando aquelas com função de modificar a estrutura da cromatina e responsáveis por regular a expressão genica via modificação química de histonas para locais de transcrição (ZHANG; TAO; LIAO, 2017). 

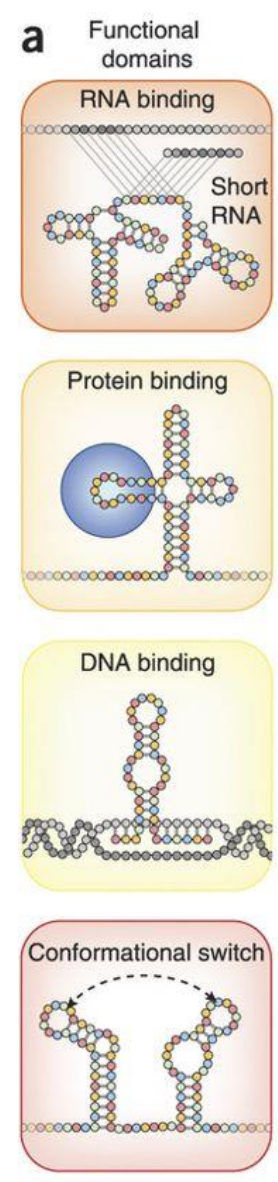

b LncRNA

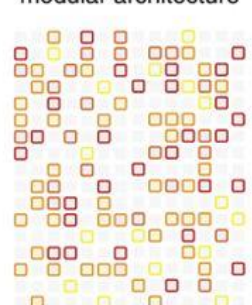

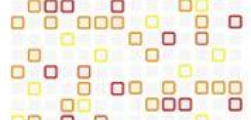
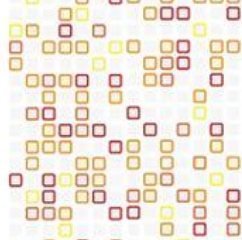

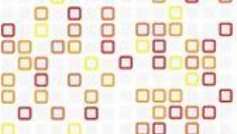

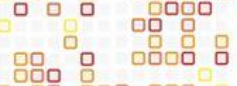

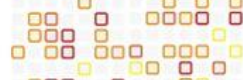

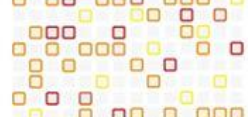

$\circ \circ \circ 00$

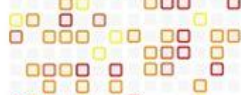

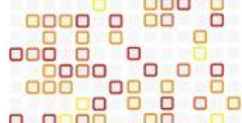

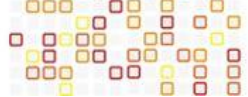

C Control device

No protein Conformational

binding ... RNA binding switch $\rightarrow$ No RNA

bina binding

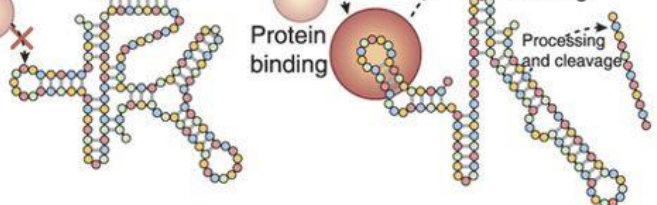

d scaffold

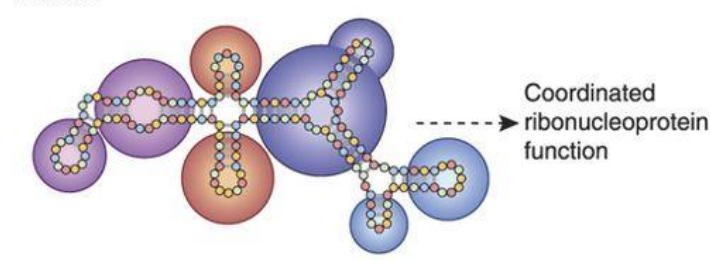

e Guide

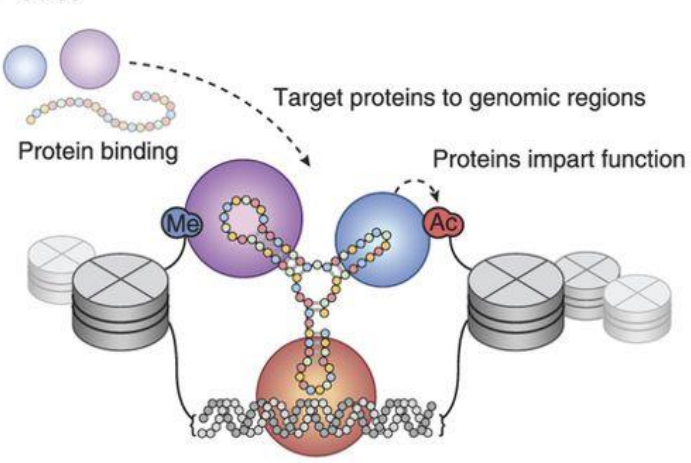

Figura 11 Estrutura e interação dos IncRNAs. a) Os IncRNAs podem apresentam diferentes sítios de ligação, denominados domínios estruturais que os possibilitam detectar ou se ligar a RNAs, proteínas e ao DNA. b) Por meio de splicing alternativo, os domínios estruturais podem combinar-se modulando essa estrutura. Em b, cada linha representa um IncRNA e as cores estão associadas aos domínios estruturais mostrados em a. Como mostrado em c, a ligação de uma fita de RNA (em cinza) impede que seja feita uma ligação com a proteína, isso possibilita que os IncRNAs possam atuar como dispositivos de controle, por meio de domínios sensoriais ou acopladores, regulando a interação com outras moléculas. d) Os IncRNAs podem estruturar um complexo molecular com outras proteínas. e) Recrutamento de proteínas e direcionamento de seus sítios catalíticos para locais alvos na cromatina (Fonte: Mercer, 2013) 
A

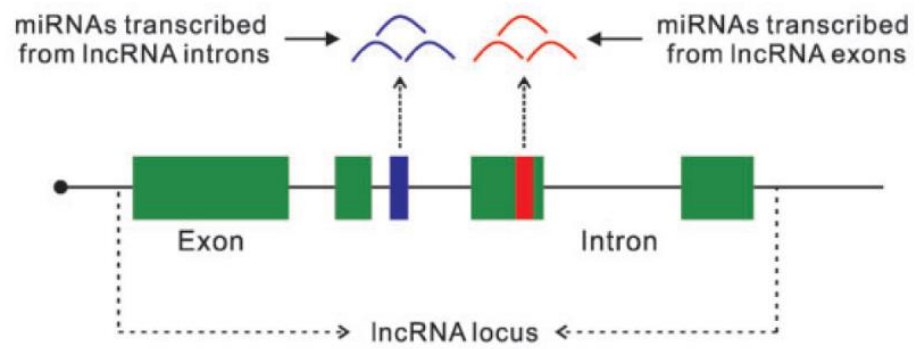

B

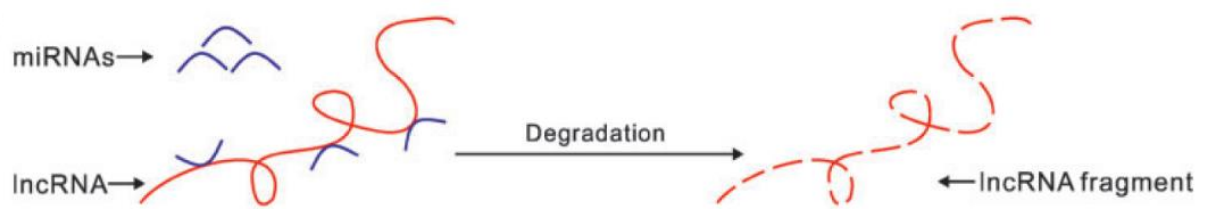

C

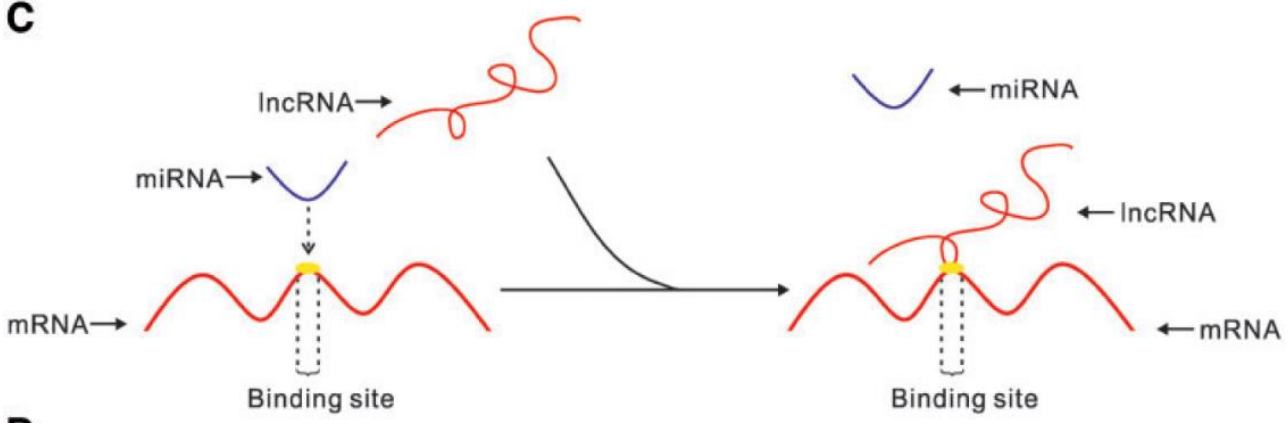

D

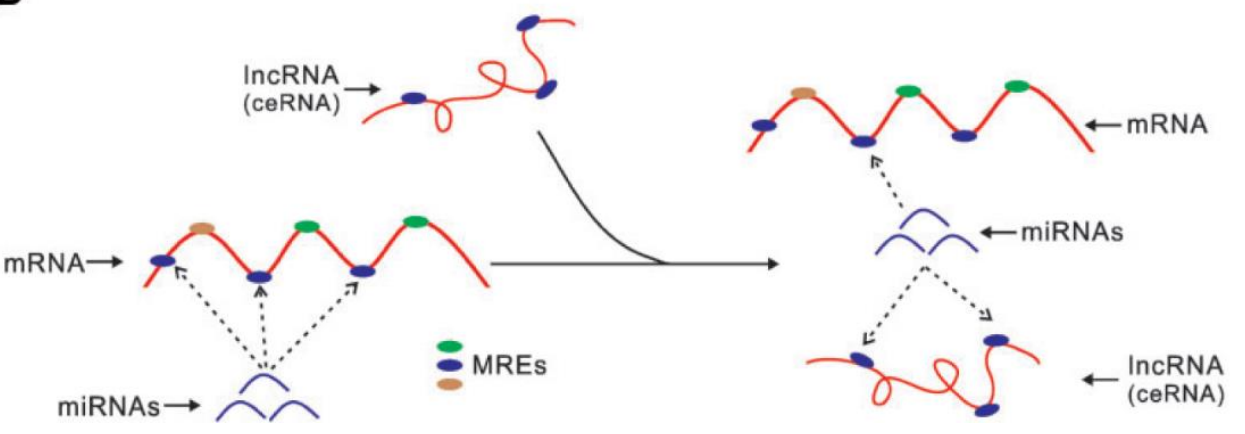

Figura 12 Diferentes interações entre LncRNAs e miRNAs. A) LncRNAs podem atuar como "gene hospedeiro" e dar origem a miRNAs. B) Os miRNAs podem promover a degradação dos IncRNAs. C) Competição entre IncRNAs e miRNAs para ligar-se ao mRNA alvo. D) IncRNAs podem atuar como esponja e atrair os miRNAs dos mRNAs alvos (Fonte: Zang, 2017) 
A posição genômica dos IncRNAs em relação ao lócus dos mRNAs codificadores de proteínas dá origem a sua classificação, podendo ser: Antisense, que representam transcritos com interseção com algum exon ou intron de genes codificantes de proteínas e se localizam na fita oposta; RNAs não codificantes intergênicos longos (lincRNAs), no qual sua origem está entre dois genes codificantes de proteínas; Sense overlapping, são os IncRNAs cujos os íntrons abrigam sequências com potencial codificação para proteínas e localiza-se na mesma fita sem sobreposição de exons; Sense intronic , IncRNAs que estão localizados dentro de introns de genes codificantes de proteínas, sem interseção com exons (Figura 13) (RINN; CHANG, 2012; KUNG; COLOGNORI; LEE, 2013; MERCER; MATTICK, 2013; IMAMURA et al., 2014).

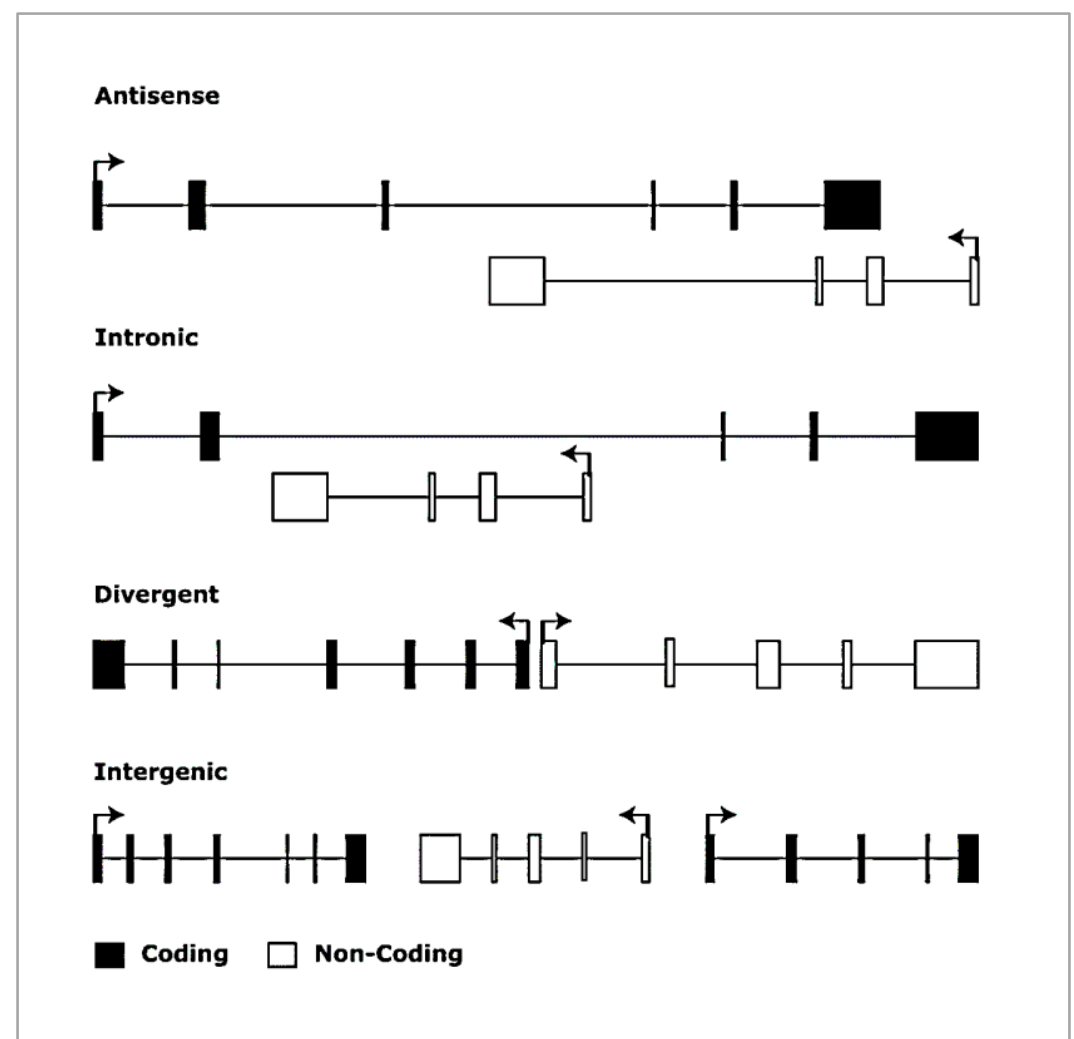

Figura 13 Classificação de acordo com a localização genômica dos IncRNAs. A localização pode ser classificada em bidirecional (divergente) e antisenso, relativo a genes codificadores de proteínas ou em íntrons de genes codificadores de proteínas. Os IncRNAs classificados como intrônicos são IncRNAs que sua localização inicia dentro de um íntron de um gene codificador de proteína em qualquer direção e termina sem sobreposição de exons. E os IncRNAs podem ser encontrados em regiões intergênicas e agrupados com genes codificadores de proteínas em complexos lócus de transcrição (Fonte: Rinn, 2012). 
No sistema imunológico, o primeiro IncRNA identificado foi o intergênico lincRNA-Cox2, responsável por ativar e inibir diferentes classes de genes com função inflamatória, por meio da interação física com vários complexos reguladores, sendo almejado como um futuro potencial para alvos farmacológicos (CARPENTER et al., 2013). Neste mesmo período, foram identificados regiões que codificam para lincRNAs responsáveis por promover o desenvolvimento e diferenciação de células T (HU et al., 2013).

Outros estudos indicam que os IncRNAs podem atuar, por exemplo, em processos como a diferenciação de células $\mathrm{TH} 17$ e $\mathrm{CD}^{+}$e ativação de mecanismos da inflamação e ativação de células T (HUANG et al., 2015; WALLAERT et al., 2017). Neste último caso, o papel do IncRNA-CD244 foi associado com uma restrição da ativação excessiva de células T CD8 ${ }^{+}$(WANG et al., 2015). 
Hipótese 


\section{Hipóteses}

1) $O$ gene Aire regula simultaneamente a expressão de mRNAs e de IncRNAs em células tímicas epiteliais medulares (mTECs) (Figura 8).

2) A interação com timócitos modula a expressão de IncRNAs em células mTECs. 
Objetivos 


\section{Objetivos}

\subsection{Objetivo geral}

Avaliar a expressão de mRNAs e de IncRNAs em células mTEC e a modulação dessas espécies de RNAs sob a influência da adesão com timócitos.

\subsection{Objetivos específicos}

- Avaliar a expressão de mRNAs em células mTECs linhagem 3.10 Aire+/+ após a adesão com timócitos.

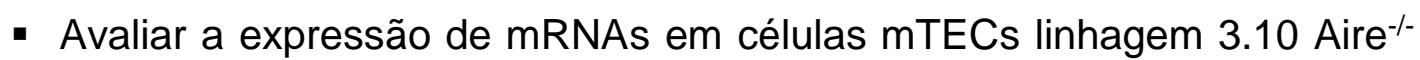
editadas por CRISPR-Cas9 após a adesão com timócitos.

- Avaliar a expressão de IncRNAs em células mTECs linhagem 3.10 Aire+/+ editadas por CRISPR-Cas9 após a adesão com timócitos.

- Avaliar a expressão de IncRNAs em células mTECs linhagem 3.10 Aire ${ }^{-/-}$ editadas por CRISPR-Cas9 após a adesão com timócitos.

- Avaliar os processos biológicos nos quais estão envolvidos os RNAs diferencialmente expressos.

- Caracterizar os IncRNAs diferencialmente expressos.

- Localização cromossômica dos IncRNAs diferencialmente expressos.

- Avaliar o potencial codificador dos IncRNAs diferencialmente expressos.

- Identificar os genes codificadores de proteínas mais próximos no genoma dos IncRNAs diferencialmente expressos.

- Avaliar a interação entre os IncRNAs e os seus mRNAs alvos (interação RNA-RNA). 
Delineamento experimental 


\section{Delineamento experimental}

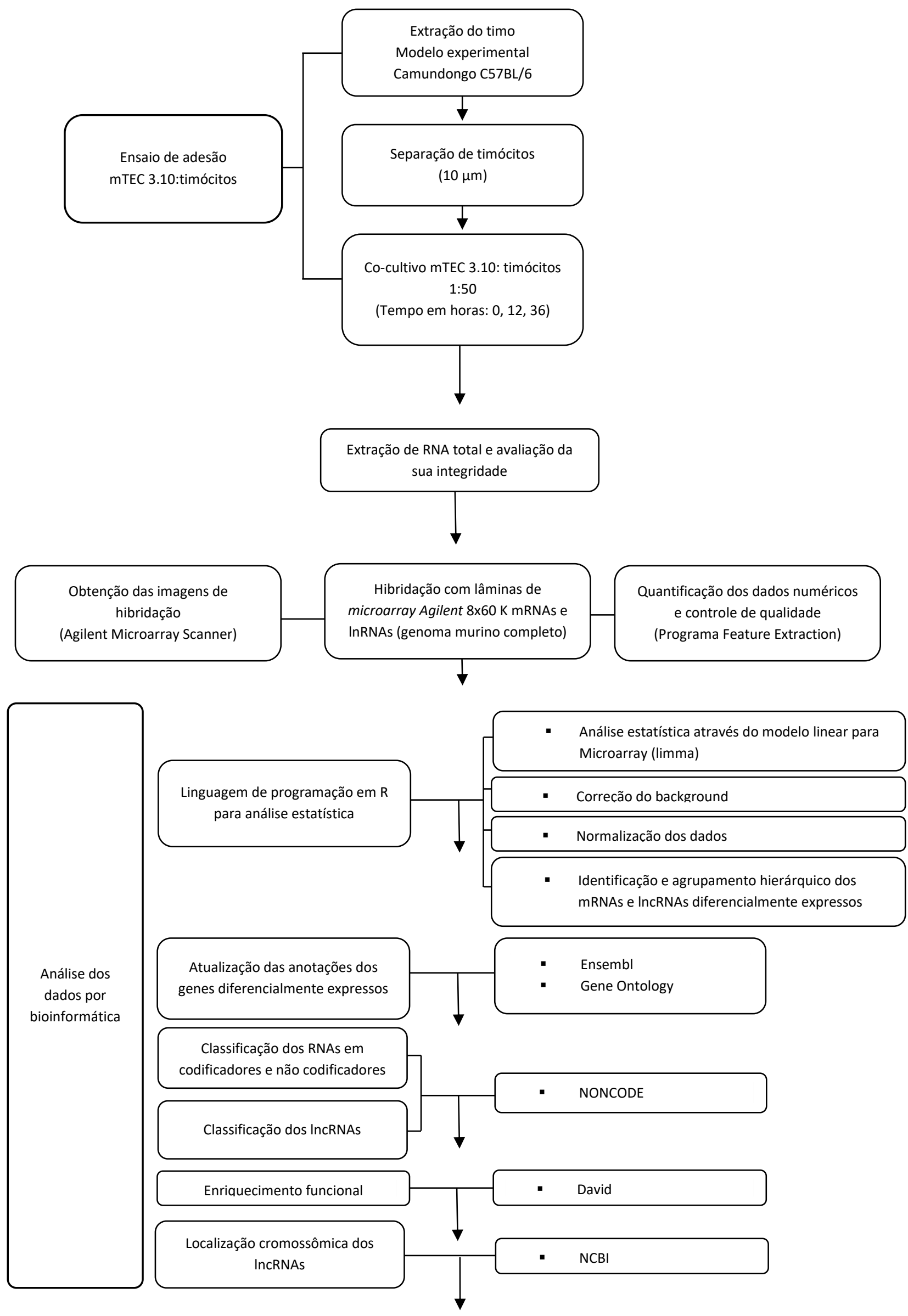




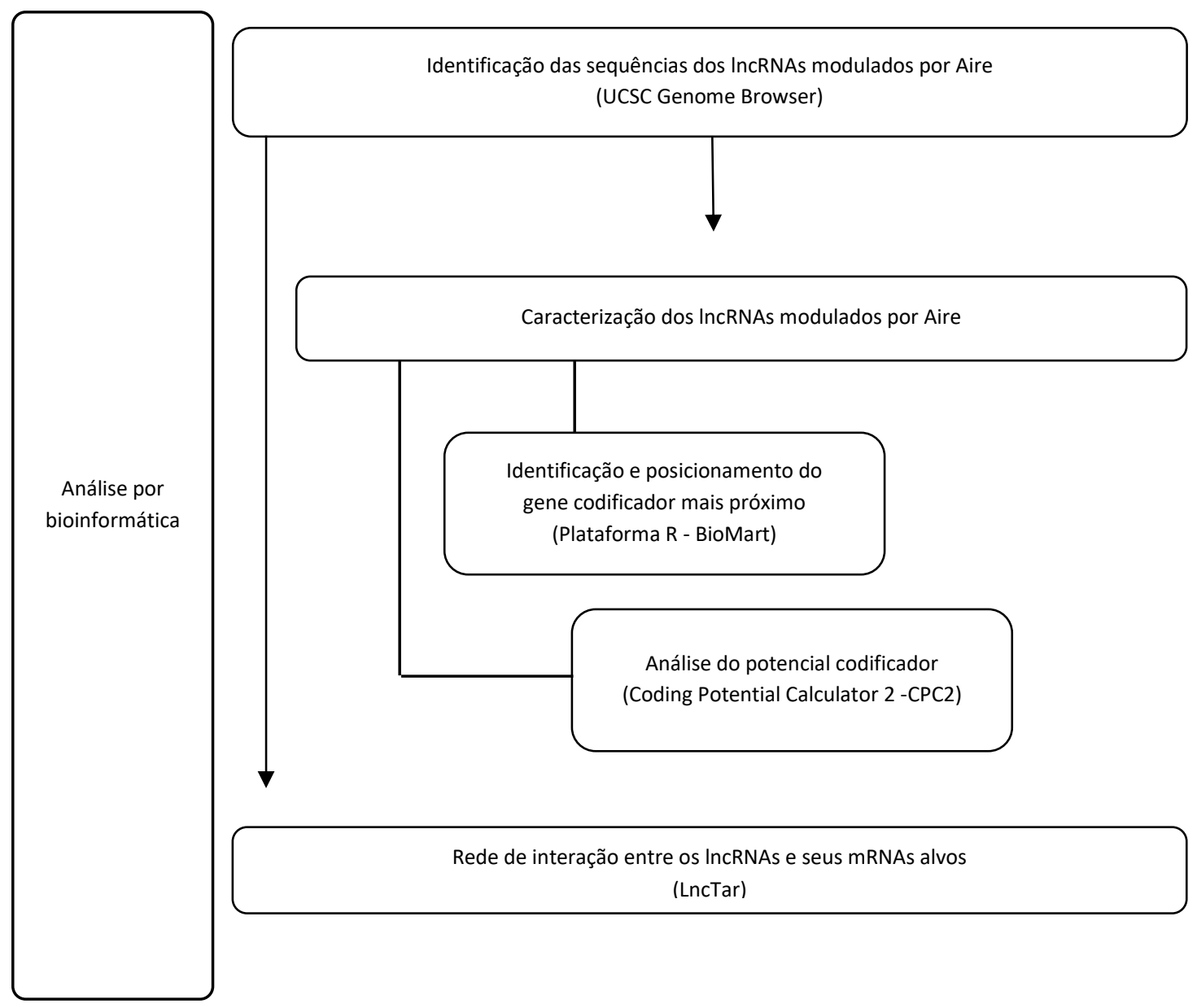


Material e Métodos 


\section{Material e Métodos}

\subsection{Linhagem celular}

Utilizamos a linhagem de células tímicas epiteliais medulares (Mus musculus, linhagem mTEC 3.10, MHC II+ CD80+) gentilmente cedida pelo Prof. Dr. Wilson Savino, do Laboratório de Pesquisas sobre o Timo da Fundação Instituto Oswaldo Cruz (FIOCRUZ), Rio de Janeiro-RJ, Brasil.

As mTECs 3.10 foram estabelecidas a partir do timo de camundongos recém-nascidos da linhagem C57BL/6 e fenotipadas como células Epcam ${ }^{+}$Ly51UEA1 ${ }^{+} \mathrm{CD} 80^{+} \mathrm{MHC}-\mathrm{II}^{+}$e que expressam o gene Autoimmune regulator (Aire) (Macedo et al., 2009, Pezzi et al., 2016). As células mTEC 3.10 são aderentes e foram cultivadas em garrafas de $75 \mathrm{~cm}^{2}$ contendo $15 \mathrm{~mL}$ de meio RPMI 1640 (Gibco - El Paso. TX, USA) suplementado com 10\% e soro fetal bovino (SFB) (Cultilab - Campinas, SP, Brasil), e mantidas a $37^{\circ} \mathrm{C}$ em estufa com atmosfera de $5 \%$ de $\mathrm{CO}_{2}$.

\subsubsection{Clones de mTEC 3.10 Aire nocaute obtidas por CRISPR-Cas9}

Neste trabalho foram utilizados clones de células mTECs nocaute $(K O)$ no gene Aire (mTEC Aire - /) obtidas por meio da ferramenta de edição gênica CRISPR-Cas9 num estudo prévio realizado em nosso laboratório (SpeckHernandez et al 2018). O clone denominado mTEC3.10E6 teve como alvo o exon 3 do gene Aire (sequência CCCCTTGCTGGTCCCAAGGCCG cuja localização genômica é GRCm38:10:78030995-78031017) e especificamente no domínio NLS (Sinal de Localização Nuclear). O clone mTEC3.10E6 foi caracterizado como portador de mutações do tipo indel afetando ambos os alelos de Aire (nocaute heterozigoto composto). No alelo 1 de Aire, há dois tipos de mutação: substituição $T>G$ (na posição 351 do $\mathrm{mRNA}$ ) seguida por uma deleção de nove pb (GCTGGTCCC, posições 352-360 do mRNA) transcrevendo um RNAm de 1.647 nt. Já no alelo 2, houve uma única deleção de $G$ na posição 352 do mRNA que transcrevendo um mRNA de Aire com 1.655 nt.

Análises in silico da tradução da proteína Aire no clone mTEC 3.10E6 e alinhamento das sequências polipeptídicas por meio do programa Clustal 
Omega mostraram que a substituição $T>G$ no alelo 1 resultou numa mutação silenciosa L118L, enquanto que a deleção de nove pb provocou uma um erro de leitura do tipo frameshift provocando uma deleção de três resíduos de aminoácidos (A119_P121 del) e consequentemente uma proteína Aire menor, com 548 resíduos de aminoácidos.

Análises usando o programa Provean, o qual caracteriza os efeitos funcionais das variações na sequência de aminoácidos mostrou que a deleção dos 9 nt no alelo 1 foi deletéria para o domínio NLS da proteína Aire. Já para o alelo 2, a deleção de um $\mathrm{G}$ resultou num códon de parada TGA na posição 352 do mRNA e, consequentemente, uma proteína Aire truncada de 158 resíduos de aminoácidos. De acordo com essas análises, o clone mTEC $3.10 \mathrm{E} 6$ é considerado um Aire nocaute heterozigoto composto que expressa uma proteína Aire deletéria proveniente do alelo 1 (Speck-Hernandez et al 2018).

\subsubsection{Timectomia e obtenção dos timócitos}

Para a obtenção de timócitos, os camundongos foram mortos por inalação de $\mathrm{CO}_{2}$. Os timos de animais com cinco a seis semanas de idade foram removidoa por cirurgia e pinçados para a liberação dos timócitos em placa de Petri contendo meio de cultura RPMI 1640. Uma malha de nylon com porosidade de $10 \mu \mathrm{m}$ (Sefar Inc. Depew, NY, USA) foi utilizada para separação dos timócitos. A suspensão de timócitos foi centrifugada por 5 minutos a 1000xg e lavada em PBS. Os timócitos foram então utilizados no ensaio de adesão com as células mTEC 3.10 wt ou o clone mTEC 3.10E6. O projeto científico foi previamente aprovado pelo Comitê de Ética CEUA da Faculdade de Medicina de Ribeirão Preto, USP, protocolo número 006/2016-1.

\subsection{Ensaio de adesão celular (mTEC-timócito)}

Os timócitos foram co-cultivados com células mTECs 3.10 em cultura (mTEC 3.10 wt ou o clone mTEC 3.10E6) na proporção de 50 timócitos para cada célula mTEC. Os timócitos e as mTECs (co-cultivo) foram incubados durante 0,12 ou 36 horas em atmosfera a $37^{\circ} \mathrm{C}$ e $5 \% \mathrm{CO}_{2}$. Após o período de adesão, os timócitos não aderidos foram retirados com cuidado e as garrafas de 
cultivo lavadas com PBS (1x) pré-aquecido a $37^{\circ} \mathrm{C}$ para a retirada dos timócitos fracamente aderidos. Em seguida, as garrafas foram lavadas novamente, agora com PBS (1X) gelado para a retirada dos timócitos aderidos e posterior contagem.

As células mTEC 3.10 foram destacadas das garrafas de cultura de 25 $\mathrm{cm}^{2}$ utilizando-se $5 \mathrm{ml}$ de solução de tripsina $1 \times$ (2.5g de tripsina suína por litro em HBSS) $+0.5 \mathrm{ml}$ de EDTA pH 8.0 por 5 minutos, seguido de inativação da tripsina com meio de cultura + SBF e colhidas por centrifugação a $1000 \times \mathrm{g}$ durante 5 minutos. Tanto os timócitos quanto as mTECs 3.10 foram quantificados no contador automatizado Cellometer Auto T4 Cell Viability Counter Nexcelom Bioscience (Lawrence, MA, USA). De cada garrafa foi calculada a razão entre 0 número de timócitos aderidos e o número de mTECs. A partir desses valores foi calculado o índice de adesão (IA) cujo cálculo é explicado abaixo. O ensaio foi realizado em triplicada.

Índice de adesão $(I A)=\frac{N}{M}$

onde $N$ é referente ao número de timócitos aderidos

e M ao número de células mTECs

\subsection{Extração de RNA total}

A extração de RNA total foi realizada utilizando o kit mirVana miRNA Isolation Kit da Ambion (Grand Island, NY, USA). Foram selecionados para extração de RNA a linhagem de mTEC 3.10 wt e o clone mTEC 3.10E6 Aire\% (KO).

As células foram destacadas das garrafas de cultura de $25 \mathrm{~cm} 2$ por meio da adição de $5 \mathrm{ml}$ de solução de tripsina/EDTA por 5 minutos. A tripsina foi inativada com meio de cultura contendo $10 \%$ de SFB e as células foram colhidas por centrifugação a $1000 \times \mathrm{g}$ durante 5 minutos. $O$ botão de células resultantes 
foi lavado duas vezes com PBS estéril e então adicionamos $1 \mathrm{ml}$ de solução de lise do kit de extração de RNA.

A mistura foi agitada vigorosamente (pipetagens sucessivas seguidas de 10 segundos no vórtex) para lisar completamente as células. Adicionou-se $100 \mu \mathrm{l}$ de miRNA Homogenate Additive e misturou-se bem (vórtex por 15 segundos). A mistura foi deixada em banho de gelo por 10 minutos. Em seguida foi adicionado $1 \mathrm{ml}$ de fenol ácido-clorofórmio, e a mistura foi agitada vigorosamente no vórtex por mais 60 segundos.

O lisado foi centrifugado a $10.000 \times \mathrm{g}$ por 5 minutos em temperatura ambiente. A fase aquosa foi cuidadosamente transferida para um novo tubo, e então foi adicionado etanol 100\% (pelo menos 1,5 vezes do volume recuperado após a centrifugação) à temperatura ambiente.

Para cada amostra foi montada uma coluna com tubo coletor, adicionouse $700 \mu \mathrm{l}$ da mistura (fase aquosa da extração + etanol) em cada coluna e as mesmas foram centrifugadas por 15 segundos a $10.000 \times \mathrm{g}$. O líquido foi descartado e o procedimento repetido até que toda a mistura fosse filtrada. Por último, $700 \mu \mathrm{l}$ de miRNA Wash Solution 1 foram adicionados a cada uma das colunas, as quais foram centrifugadas por 10 segundos a $10.000 \mathrm{xg}$.

O líquido foi descartado, e então $500 \mu l$ de miRNA Wash Solution $2 / 3$ foi aplicado na coluna e centrifugado por 10 segundos a $10.000 \times$ g. O último passo foi repetido e, após descartar o líquido, o tubo foi centrifugado por 1 minuto para remover resíduos líquidos do filtro. A coluna foi transferida para um novo tubo coletor, e a ela foram adicionados $100 \mu \mathrm{l}$ de água MilliQ/DEPC pré-aquecida a $95^{\circ} \mathrm{C}$. O tubo foi centrifugado por 30 segundos para a recuperação do RNA total.

\subsection{Quantificação e avaliação do grau de pureza das preparações de RNA total}

A quantificação das amostras de RNA total foi realizada por espectrofotometria UV no aparelho NanoDrop ND-1000 (NanoDrop Products, Wilmington, $D E, U S A)$. Neste trabalho consideramos que uma unidade (1U) de absorbância A260 corresponde a 40 $\mathrm{g}$ de RNA/ml.

Além disso, avaliamos pureza das preparações por meio de cálculo das razões absorbância em diferentes comprimentos de onda de UV. Só utilizamos 
amostras livres de fenol que apresentaram razão $A_{260 /} A_{230}$ entre 1.8 a 2.0 e livres

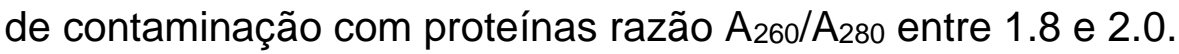

\subsection{Avaliação da integridade das preparações de RNA total}

A integridade das preparações de RNA total foi avaliada por eletroforese microfluídica utilizando RNA 6000 Nano chips e um aparelho Agilent 2100 Bioanalyzer ${ }^{\circledR}$ Agilent Technologies (Santa Clara, CA, USA). Antes de iniciar o preparo do gel para a eletroforese, todos os reagentes, que anteriormente estavam a $4^{\circ} \mathrm{C}$, foram mantidos por 30 minutos a temperatura ambiente.

Decorrido o tempo, iniciou-se o preparo do gel pipetando $550 \mu$ do RNA $6000 \mathrm{Nano}$ gel em uma coluna com filtro e centrifugou-se a $1.500 \mathrm{x}$ g durante 10 minutos em temperatura ambiente. Uma alíquota de $65 \mu \mathrm{l}$ foi colocada em um tubo de $0,5 \mathrm{ml}$ livre de nucleases e em seguida, foi adicionado $1 \mu \mathrm{l}$ de RNA 6000 Nano Dye.

A amostra foi submetida a agitação em vórtex por 10 segundos, seguida de centrifugação a $13.000 \times$ g por 10 minutos em temperatura ambiente. Em seguida, iniciou-se o preparo do RNA 6000 Nano chip que foi colocado na priming station com os ajustes corretos para a leitura de RNAs. Primeiramente foram pipetados $9 \mu \mathrm{l}$ da mistura gel/dye na região $\mathrm{G}$ indicada no chip e com o auxílio de uma seringa acoplada à priming station o gel foi distribuído por todo 0 chip. Em seguida, outros $9 \mu \mathrm{l}$ da mistura foram pipetados nos demais pontos indicados com a letra $\mathrm{G}$.

Foram pipetados $5 \mu \mathrm{l}$ do RNA 6000 Nano Marker em cada uma das amostras, bem como na posição do marcador e $1 \mu \mathrm{l}$ do marcador na posição indicada. Por último, pipetou-se $\mu \mathrm{l}$ de cada amostra de RNA nos respectivos poços marcados de 1 a 12 e com a ajuda de um vórtex IKA MS 3 (Manca, Hong Kong, $\mathrm{CHN}$ ), agitou-se o chip horizontalmente a $2.200 \mathrm{rpm}$ por 1 minuto e em seguida, colocou-se o chip no bioanalisador para proceder-se a corrida eletroforética.

O resultado (eletroferograma e densitometria dos géis) foi obtido pelo Agilent 2100 Expert Software após 30 minutos de corrida. Somente as amostras que apresentaram picos correspondentes aos padrões das espécies de RNAr 
28S, 18S, 5S e RNAt 4S e com RNA Integrity Number (RIN) $\geq 9.0$ foram utilizadas nos experimentos.

\subsection{Preparação do extrato proteico}

Com a finalidade de avaliar possíveis variações na expressão da proteína Aire comparando as células mTEC 3.10 wt vs clone KO mTEC 3.10E6, foi aplicado o método western-blot. Para isso, foi necessário preparar o extrato proteico total dessas células. Aproximadamente $5 \times 10^{5}$ células foram semeadas em garrafas de cultura de $25 \mathrm{~cm}^{2}$ contendo $5 \mathrm{ml}$ de meio RPMI 1640 e $10 \%$ de soro fetal bovino (SFB). As células foram destacadas das garrafas de cultura de $25 \mathrm{~cm}^{3}$ utilizando-se $5 \mathrm{ml}$ de solução de tripsina $1 \times(2.5 \mathrm{~g}$ de tripsina suína por litro em HBSS) $+0.5 \mathrm{ml}$ de EDTA pH 8.0 por 5 minutos, seguido da inativação da tripsina com meio de cultura + SBF e colhidas por centrifugação a $1000 \times \mathrm{g}$ durante 5 minutos. As células foram lavadas três vezes com PBS 1x, e centrifugadas a $1000 \times \mathrm{g}$ durante 5 minutos. Foram adicionados $400 \mu$ do tampão RIPA com inibidores de protease e com o auxílio de um sonicador as células foram lisadas. O homogeneizado foi então centrifugado a 10000 x g por 30 minutos a $4^{\circ} \mathrm{C}$. O sobrenadante rico em proteínas (extrato proteico total) foi utilizado na detecção da proteína Aire pelo método de western-blot.

\section{Eletroforese de proteínas em gel de poliacrilamida na presença de SDS (SDS-PAGE)}

A eletroforese em gel denaturante (SDS-PAGE) foi realizada utilizando-se um sistema de tampão descontínuo. Foram utilizados mini-géis de poliacrilamida (10 x $8 \times 0,075 \mathrm{~cm})$, com gel de empilhamento de $4 \%$ e géis de separação de $10 \%$ ou $12 \%$. As amostras para eletroforese foram preparadas obedecendo-se a proporção em volume 3:1, respectivamente, de amostra e tampão de amostra concentrado 4x (240 mM Tris-HCl pH 6,8; 8\% SDS; 40\% glicerol contendo azul de bromofenol). As amostras foram aquecidas por 5 minutos a $95^{\circ} \mathrm{C}$ a seco. $\mathrm{O}$ tampão dos eletrodos conteve 25mM Tris- $\mathrm{HCl}$, $\mathrm{pH} 8,3 ; 190 \mathrm{mM}$ glicina; 0,1\% SDS. 


\section{Western Blot}

Após a corrida de SDS-PAGE, as proteínas foram eletrotransferidas a 70 $\checkmark$ para uma membrana de polyvinylidene difluoride (PVEF), utilizando-se $25 \mathrm{mM}$ TrisHCl, $190 \mathrm{mM}$ glicina, 20\% metanol e 0,1\% SDS como tampão de transferência. Após a transferência, a membrana foi corada com Ponceau $\mathrm{S}$ 0,2\% em 3\% ácido tricloracético por 5 minutos. Em seguida, a membrana foi lavada com água deionizada e bloqueada por uma hora em leite desnatado Molico a 5\% preparado em TBS-Tween (50 mM Tris- $\mathrm{HCl}$, pH 8,0; $150 \mathrm{mM} \mathrm{NaCl}$; $0,1 \%$ Tween-20). Após o bloqueio, a membrana foi incubada com o anticorpo primário Monoclonal Anti-Aire C- 2 Santa Cruz Biotechnology ${ }^{\circledR}$, inc (Dallas, Texas, USA), devidamente diluído em TBS-T, por uma hora, seguida de lavagens com TBS-T por cinco vezes de 5 minutos. Em seguida, a membrana foi incubada com o anticorpo secundário conjugado com peroxidase (diluído 1:25000 em TBS-T) por 50 minutos. Após incubação fez-se a lavagem da membrana em TBS-T por 5 vezes de 5 minutos e a revelação foi feita através do aparelho ImageQuant ${ }^{\mathrm{TM}}$ LAS 500 Ge Life Sciences (Piscataway, NJ, USA), utilizando-se o substrato apropriado para a peroxidase (Luminata ${ }^{\mathrm{TM}}$ Forte Merck Millipore). A reação foi conduzida protegida da luz em diferentes intervalos de exposição.

\subsection{Oligomicroarrays}

A análise do transcriptoma das células mTEC 3.10 wt ou Aire KO mTEC 3.10 E6 foi realizado por meio da tecnologia de hibridações com oligomicroarrays da Agilent SurePrint G3 Mouse GE 8 × 60K Microarray Kit (Agilent Technologies, Santa Clara, CA, USA) (AMADID: 748091). Os microarrays continham o genoma funcional murinho (Mus musculus) completo. Os microarrays continham 60.000 oligos-sondas de 60 mer preparados pelo processo SurePrint (sistema de impressão) em lâminas de vidro $(2,5 \times 7,5 \mathrm{~cm})$ incluindo sondas de mRNA e de IncRNAs (genoma do camundongo anotado em julho de 2007 = NCBI37/mm9). Utilizamos a metodologia monocolor cianina 3, verde (Сy3) e os procedimentos de amplificação e marcação dos RNAs foram feitos com o Quick Amp Labeling Kit One-Color (Agilent Technologies, Santa Clara, CA, USA) a partir de $100 \mathrm{ng}$ 
de RNA total. Foram misturadas as amostras de RNA controle (spike-in) com 100 ng de RNA total para realização da etapa de transcrição reversa com a enzima transcriptase reversa Monoley Murine Leukemia Virus - Reverse Transcriptase (MMLV-RT). Além disso, foram utilizados primers adaptados com timinas $(T)$ consecutivas acopladas a um promotor T7 para síntese de cDNAs de dupla fita. Após essa reação, a enzima T7 RNA polimerase foi adicionada juntamente com nucleotídeos marcados com Cy3 (síntese de RNA complementar, cRNAs) e sua posterior amplificação. As amostras de cRNAs foram purificadas e hibridadas em lâminas de microarrays em câmaras de hibridação Agilent Microarray Hibridization Chambers (Agilent Technologies, Santa Clara, CA, USA) a $65^{\circ} \mathrm{C}$ por 17 horas em um forno rotativo (Agilent Technologies). As lâminas foram lavadas com os tampões GE Wash Buffer 1 e GE Wash Buffer 2.

\subsection{Análise dos dados de microarrays}

As lâminas de microarrays foram então escaneadas num aparelho DNA Microarray Scanner (Agilent) e as imagens de hibridação foram salvas e convertidas em valores numéricos com auxílio do programa Feature Extraction Agilent. Os dados numéricos foram então analisados no ambiente $R$ (versão 3.3.2 - R Development Core Team, 2011 disponível em R Project for Statistical Computing (https://www.r-project.org/), que consiste em um ambiente estatísticomatemático que permite a execução de múltiplas funções, sendo amplamente empregado em análise de dados de microarray, permitindo ainda execução de cálculos e visualização gráfica dos resultados.

Foram eliminados os dados cujos valores sobrepuseram os valores de background (correção do background ou signal-background). A fim de remover as variações não biológicas capazes de afetar as medições dos níveis de expressão gênica para tornar os dados comparáveis realizamos a normalização dos mesmos. A normalização foi realizada pela metodologia quantile, método considerado robusto que corrige as diferenças nas densidades de probabilidade de todas as amostras (GALLÓN; LOUBES; MAZA, 2013). 


\subsection{Análise estatística dos dados para obtenção dos transcritos diferencialmente expressos}

Para análise dos transcritos diferencialmente expressos utilizamos as funções do pacote Limma (Linear Models for Microarray Data) (RITCHIE et al., 2007, 2015), o qual aplica um modelo linear na análise estatística e reajusta os erros padrão segundo um modelo Bayesiano (Empirical Bayes e outros métodos), usado para pedir informações através de genes que fazem as análises estáveis mesmo para experimentos com pequeno número de matrizes. $\mathrm{O}$ método de Benjamini Hochberg foi aplicado para a correção para múltiplos testes (BENJAMINI; HOCHBERG, 1995).

\subsection{Análise funcional in silico}

Os mRNAs diferencialmente expressos foram anotados e agrupados segundo suas categorias funcionais (Gene Onthology ou GO) fazendo uso da ferramenta DAVID (https://david.ncifcrf.gov/). Uma das categorias analisadas foi relacionada aos processos biológicos, sendo considerada mais significante quando exibia pelo menos três genes e um score $<0.05$ com correção de Benjamini-Hochberg.

\subsection{Identificação das sequências dos RNAs longos não codificantes}

A identificação das sequências dos IncRNAs foi feita através do University of California, Santa Cruz Genome Browser (UCSC Genome Browser), (disponível em https://genome.ucsc.edu/) de acordo com a montagem do genoma murino de dezembro de 2011 (GRCm38/mm10 - NCBIM37 - Ensembl release 67), de acordo com as posições cromossômicas e o ID das sondas, cujas sequências foram fornecidas pela Agilent. 


\subsection{Classificação dos RNAs longos não codificadores}

A classificação dos IncRNAs foi realizada de acordo com a anotação de cada um deles no UCSC Genome Browser e anotação fornecida pela Agilent referente às lâminas de microarray.

\subsection{Identificação e posicionamento dos genes codificadores mais próximos dos IncRNAs}

Por meio da plataforma $\mathrm{R}$, foi realizada a busca e posicionamento ao longo do genoma dos genes codificadores mais próximos aos IncRNAs. Também utilizamos a plataforma $\mathrm{R}$ e a interface de banco de dados do pacote biomaRt (https://www.ensembl.org/biomart/martview/) (biblioteca baixada pelo Bioconductor). O pacote biomaRt oferece acesso aos principais bancos de dados, inclusive Ensembl, onde a busca foi restrita aos genes codificantes de proteínas mais próximos dos IncRNAs.

\subsection{Análise do potencial codificador dos RNA longos não codificantes utilizando o CPC 2}

A análise do potencial codificador dos IncRNAs diferencialmente expressos foi realizada através do software CPC2 (http://cpc2.cbi.pku.edu.cn/). Uma calculadora que avalia o potencial codificador de um determinado IncRNA por meio de uma técnica livre de alinhamentos. Este software utiliza um modelo de regressão logística baseado em quatro características: 1) O tamanho da Open Reading Frame (ORF, ou matriz de leitura aberta), uma vez que ORFs longas dificilmente são observadas em sequências não codificadoras; 2) A cobertura da ORF, isto é, a razão entre os comprimentos da ORF e do transcrito; 3) O Fickett TESTCODE score, que reflete o efeito combinatório possível da composição de nucleotídeos e a tendência do uso de determinado códon; e por fim o 4) hexâmero score, que determina o grau relativo de viés no uso de um hexâmero em determinada sequência (KONG et al., 2007; KANG et al., 2017). Os valores 
desse score variam de 0 a 1 . Valores próximos a 0 indicam menor potencial codificador, sendo que à medida que se aproximam de 1 indicam maior potencial codificador, com base no cutoff de 0.5 (KANG et al., 2017).

\subsection{Análise dos alvos (RNAs codificadores) de IncRNAs}

Para prever os RNAs codificadores alvos dos IncRNAs foi utilizado a ferramenta LncTar (http://www.cuilab.cn/Inctar) (LI et al., 2014). Uma ferramenta de predição in silico que integra algoritmos precisos para previsão da temperatura de melting e de dímeros de primer para a predição de interação IncRNA-mRNA criando uma matriz de interação bidimensional. O LncTar avalia a energia livre de ligação percorrendo nas sequencias todas as regiões de ligação entre as duas moléculas de RNA. Com os dados de energia livre de ligação normalizados (ndG) foi possível criar uma rede de interação utilizando o programa Cytoscape (SHANNON et al., 2003). 
Resultados 


\section{Resultados}

\subsection{Análise por Western-Blot dos efeitos das mutações de Aire}

Para observarmos o efeito das mutações do gene Aire (clone mTEC 3.10E6) na expressão da proteína, utilizamos a técnica de western-blot. Os resultados evidenciaram que o clone mTEC 3.10E6 apresenta redução significativa da quantidade de proteína AIRE total em relação as células mTECs 3.10 selvagens (WT) (Figura 14). Esses resultados corroboram aqueles publicados por Speck-Hernandez, 2018.

A)
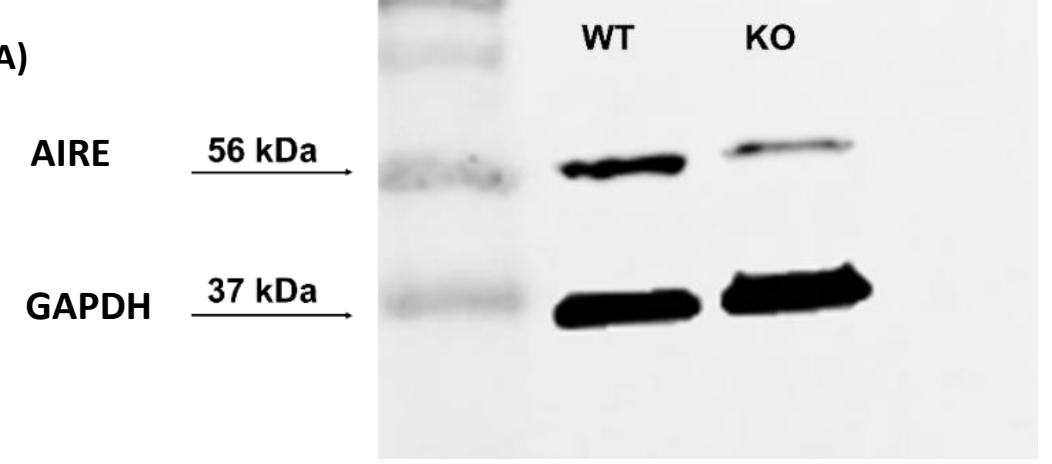

B)

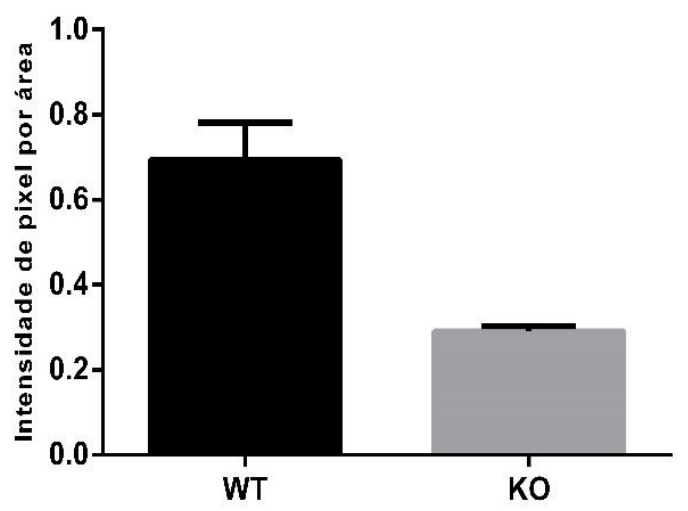

Figura 14 Expressão da proteína AIRE em células mTEC WT ou KO. Proteína AIRE ( $56 \mathrm{kDa})$ das amostras WT ou KO e marcação da proteína GAPDH ( 37 $\mathrm{kDa}$ ). B) $\mathrm{O}$ gráfico representa a quantificação da intensidade das imagens das bandas em pixels/área. Há redução de 35\% nos níveis da proteína AIRE nas células $K O m$ relação às células WT. Teste t-Student ${ }^{*} p=0,02354$. 


\subsection{Análise da adesão entre mTECs-timócitos}

Os resultados obtidos por meio do ensaio de adesão, evidenciaram uma redução na adesão entre mTECs-timócitos em células Aire KO. O co-cultivo de mTECs-timócitos por 36 horas quando comparado com 12 horas, realçou a redução do número de timócitos aderidos (Figuras 15 e 16).

Controle

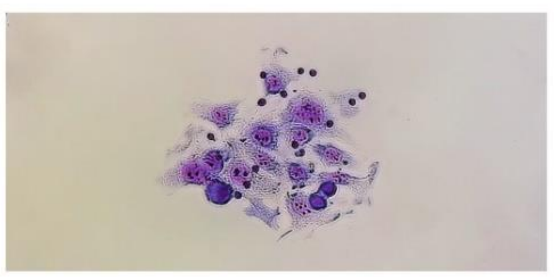

$12 \mathrm{~h}$

$36 \mathrm{~h}$

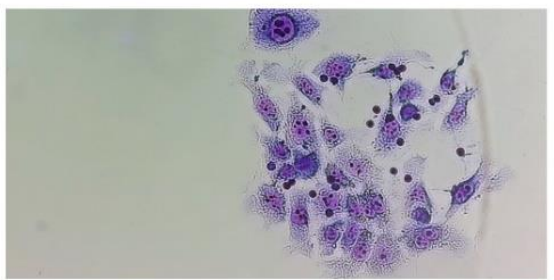

\section{Nocaute}
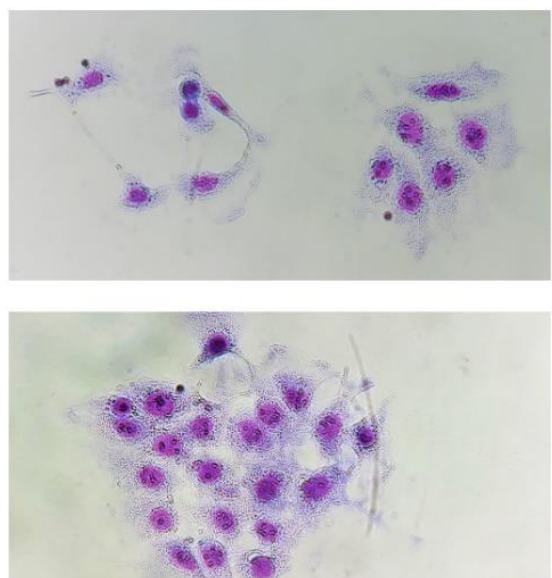

Figura 15 Ensaio de adesão mTECs-timócitos. (visualização em microscópio óptico aumento de 20x).

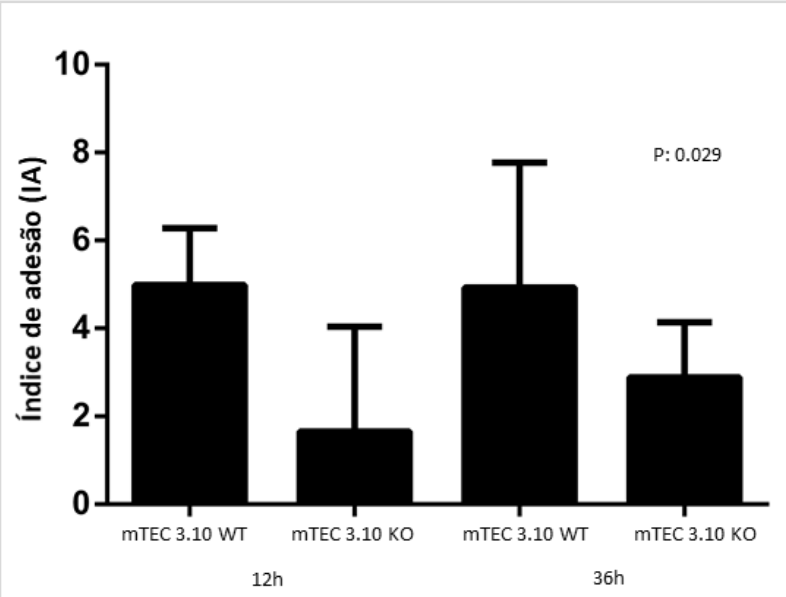

Figura 16 Análise do índice de adesão entre mTECs - timócitos. Índice de adesão foi calculado por meio da razão entre o número de timócitos aderidos pelo número de mTECs (p:0.029). 


\subsection{Análise dos genes diferencialmente expressos em mTECs wild-type co-cultivadas com timócitos.}

As primeiras análises de expressão gênica utilizando o pacote de modelo linear para microarray (limma), foram para moléculas de mRNA. Foram identificados um total de 705 mRNAs diferencialmente expressos, dentre os quais 316 sub-regulados e 389 super-regulados (Figura 17 A). Para isto, foi utilizado como cuttoff um valor de $p$ ajustado $\leq 0.05$ (Benjamini-Hochberg FDR) e fold change $\geq 1.5$ como mostrado no heatmap na figura 18. A análise das mTECs 3.10 co-cultivadas com timócitos no tempo de $12 \mathrm{~h}$ mostrou uma modulação de 175 mRNAs diferencialmente expressos, sendo destes, 84 superregulados e 91 sub-regulados. Enquanto no tempo de $36 \mathrm{~h}$ houve uma modulação de 530 mRNAs, destes 305 super-regulados e 225 sub-regulados (Figura 17 B). Com o diagrama de Venn foi possível observar uma interseção de 33 genes modulados em ambos os tempos (Figura 19) (HEBERLE et al., 2015). Os genes com uma modulação expressiva foram destacados na figura 20.

A)

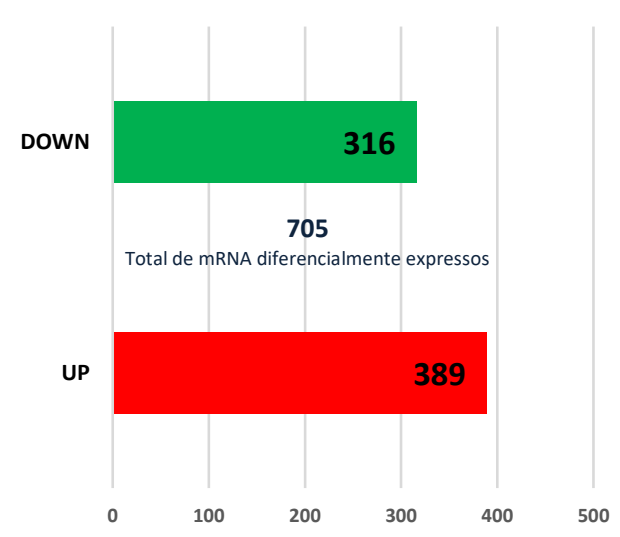

B)

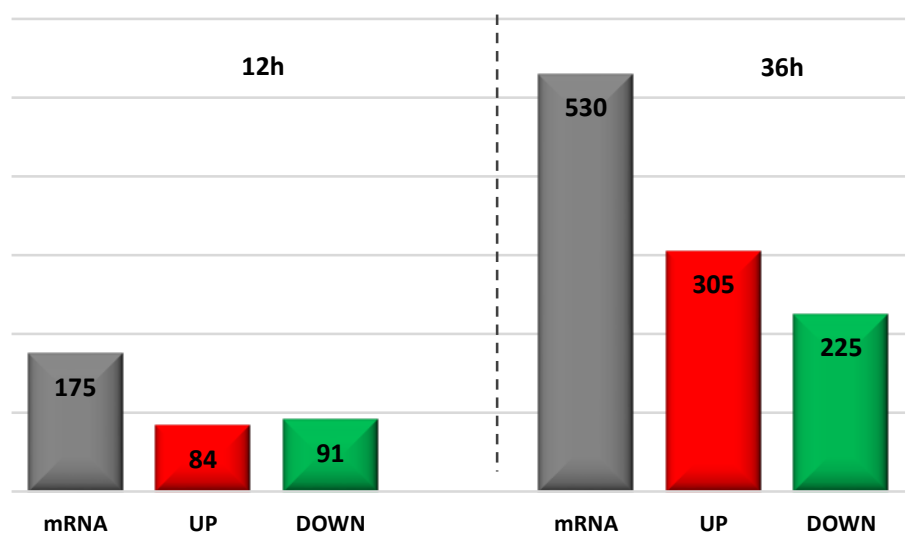

Figura 17 Análise quantitativa dos genes diferencialmente expressos. (A) Perfil de expressão de mRNAs em células mTEC 3.10 WT para o gene Aire co-cultivadas com timócitos (B) nos tempos de $12 \mathrm{e}$ 36 horas (fold change $\geq .1 .5, \mathrm{p}$ value $\leq 0.05$ ). 


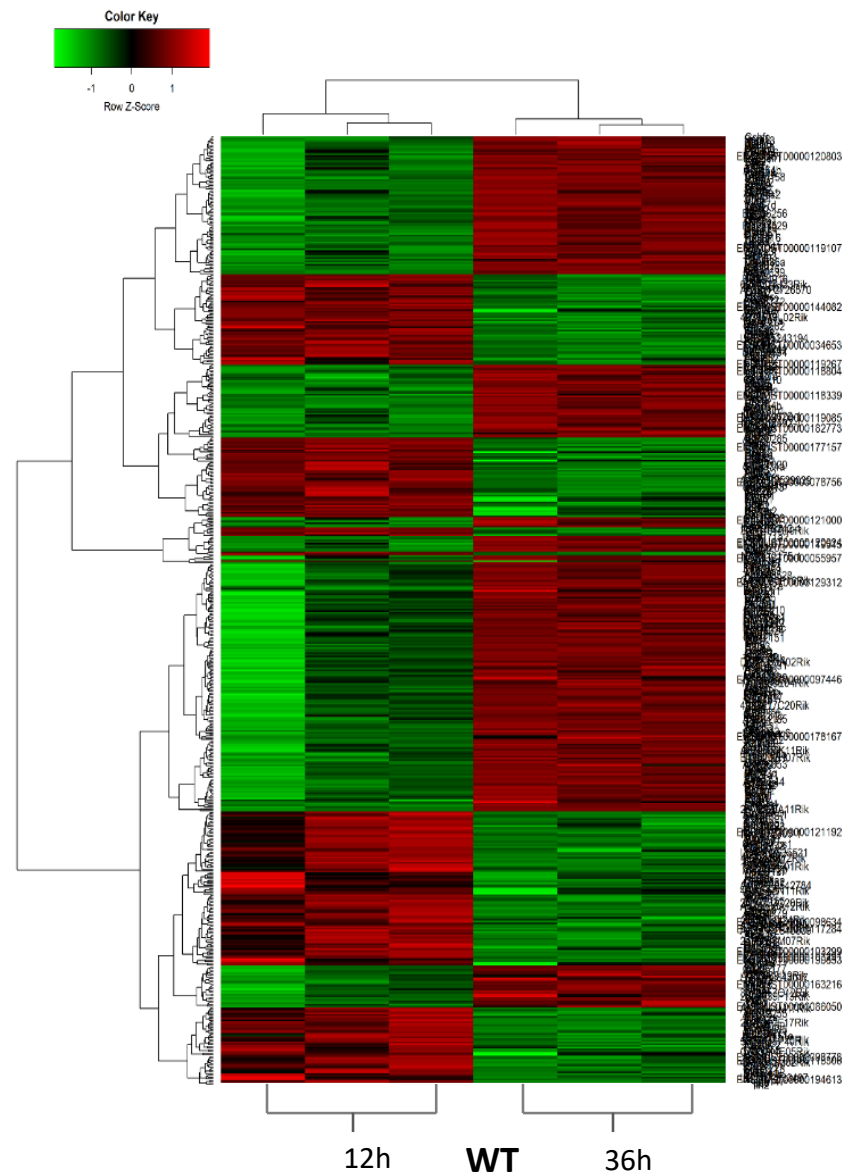

Figura 18 Heatmap evidenciando o perfil de expressão dos genes diferencialmente expressos. Heatmap do agrupamento hierárquico dos mRNAs modulados nas células mTECs WT em co-cultivo com timócitos nos tempos de $12 \mathrm{e}$ $36 \mathrm{~h}$ (fold change $\geq .1 .5, \mathrm{p}$ value $\leq 0.05$ ).

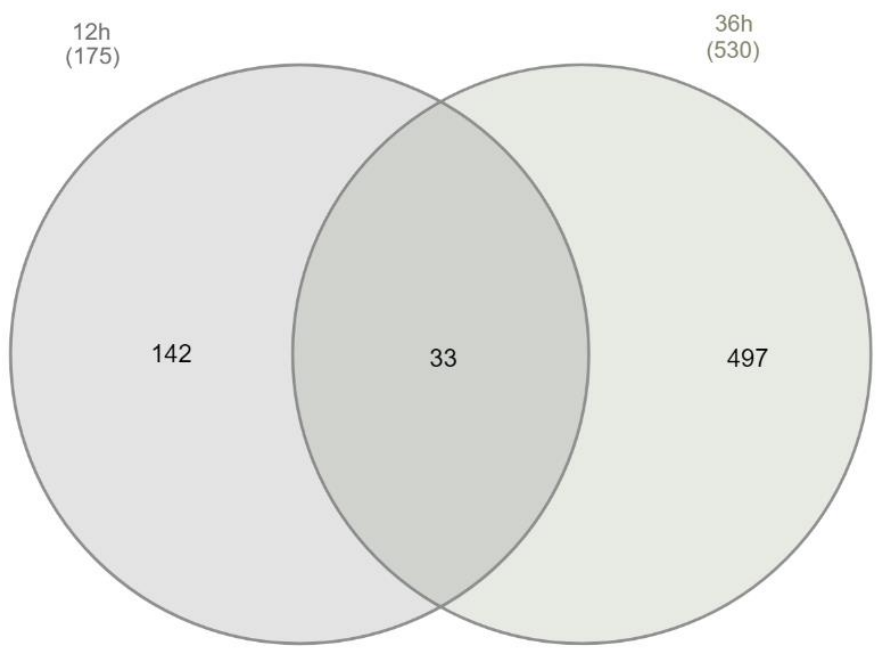

Figura 19 Diagrama de Venn. Representação por diagrama de Venn sendo observados 33 genes em comum nos tempos de $12 \mathrm{~h}$ e $36 \mathrm{~h}$ de adesão entre mTECs e timócitos. 


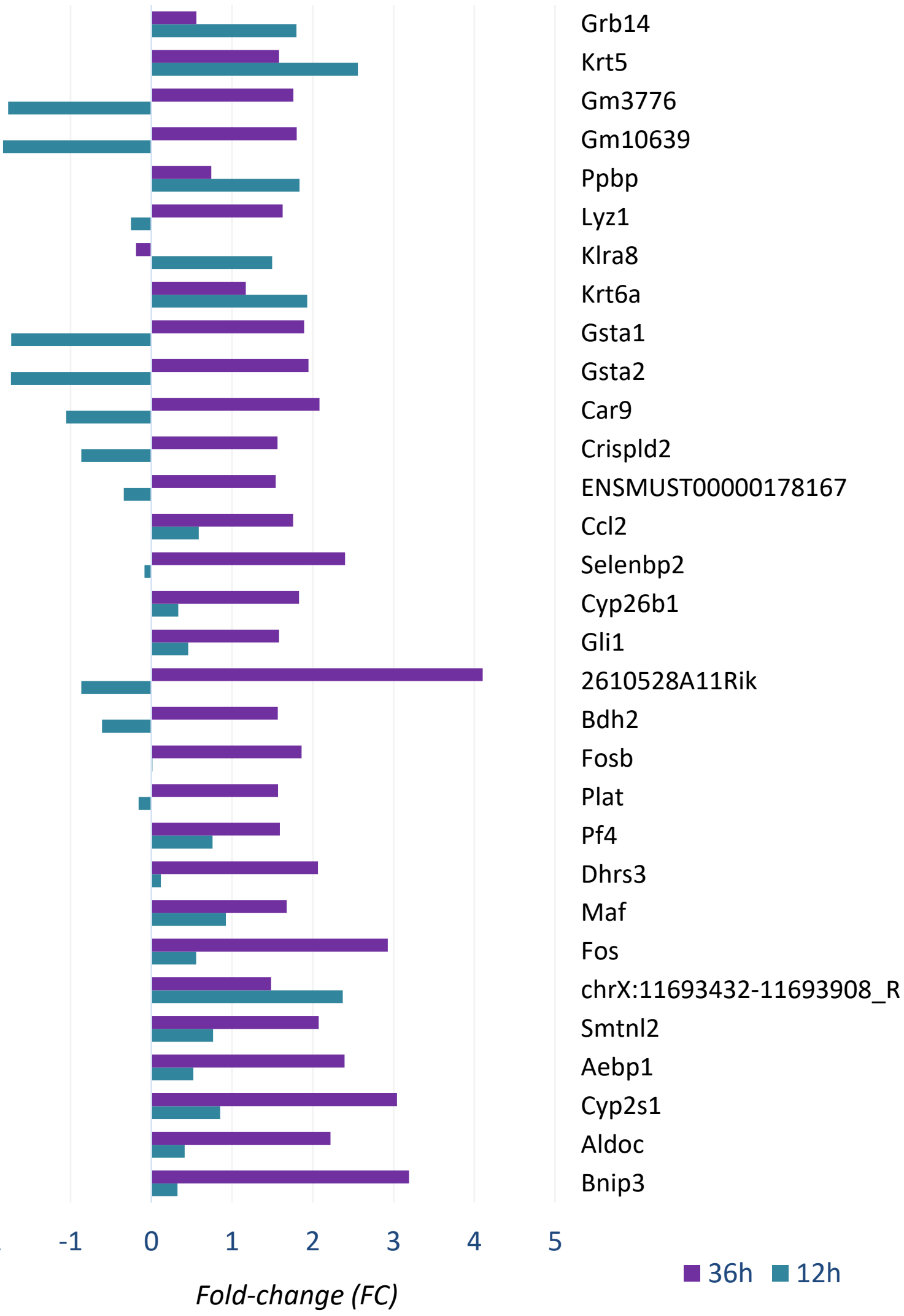

Figura 20 Top genes codificadores de proteína diferencialmente expressos em mTEC 3.10 WT co-cultivadas com timócitos nos tempos de 12 e $36 \mathrm{~h}$. 


\subsection{Análise de enriquecimento funcional (mTEC 3.10 WT)}

Com o intuito de identificar o efeito da adesão entre mTECs e timócitos (células mTEC $3.10 \mathrm{WT}$ ) foi realizado a análise funcional dos genes diferencialmente expressos através da ferramenta DAVID. Uma categoria para a predição in silico do processo biológico foi considerada significativa quando tinha no mínimo três genes envolvidos e um score $<0,05$ com correção de Benjamini-Hochberg (Figura 21)

\section{Up-regulated genes}

\section{A}

\section{$12 \mathrm{~h}$ adhesion}

DNA replication-dependent nucleosome assembly Positive regulation of gene expression, epigenetic DNA methylation on cytosine Regulation of gene silencing Innate immune response in mucosa Nucleosome assembly

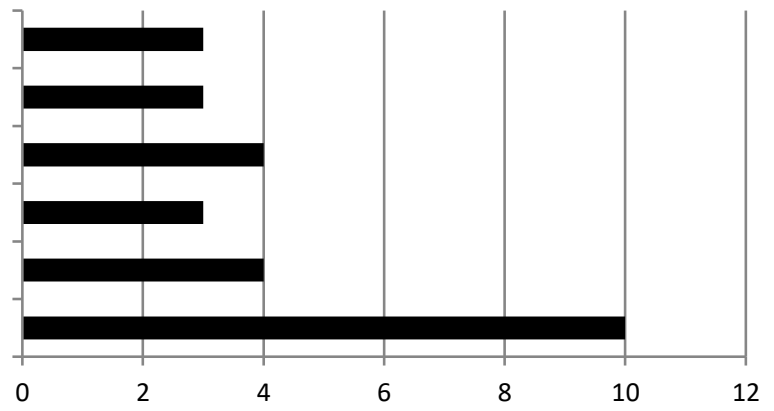

B

$36 \mathrm{~h}$ adhesion

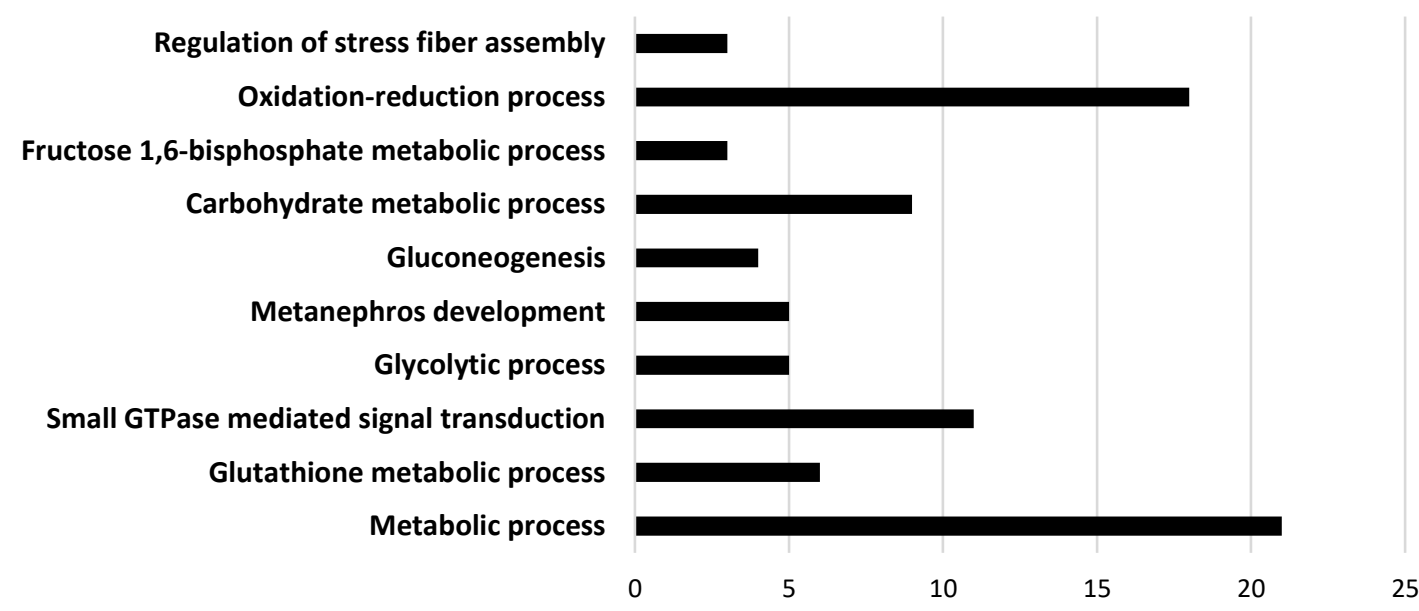




\section{Down-regulated genes}

C

$12 \mathrm{~h}$ adhesion

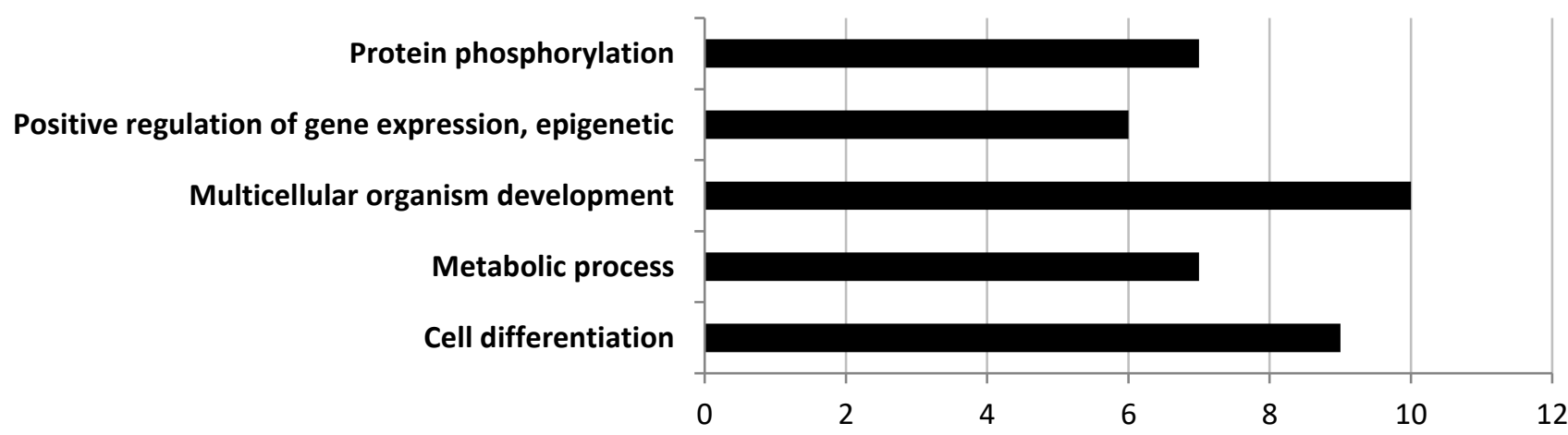

D

36h adhesion

Extracellular matrix organization

Positive regulation of DNA binding transcription

Endodermal cell differentiation

Positive regulation of ERK1 and ERK2 cascade

Chemotaxis

Peptide cross-linking

Immune response

Positive regulation of cell proliferation

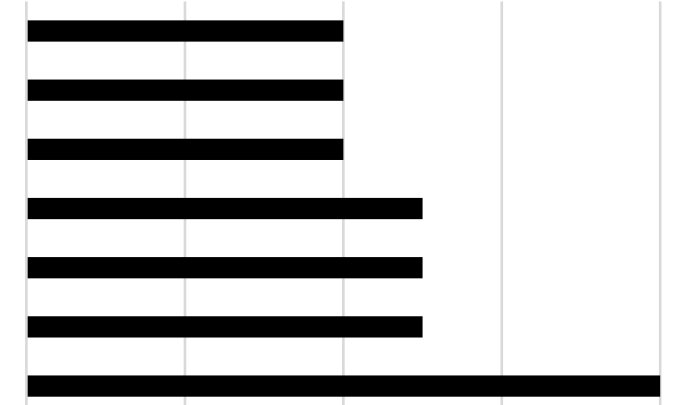

10

Figura 21 Análise in silico. (A-D) Processos biológicos dos mRNAs modulados nas células mTECs WT em co-cultivo com timócitos nos tempos de 12 e 36h (Plataforma DAVID Bioinformatics Resources 6.8 Database, score $<0,05)$. 


\subsection{Análise de mRNA em células mTEC 3.10E6 Aire KO}

Foram identificados um total de 732 mRNAs diferencialmente expressos, dentre os quais 390 sub-regulados e 342 super-regulados (Figura 22 A). A análise das mTECs 3.10 co-cultivadas com timócitos no tempo de $12 \mathrm{~h}$ mostrou 263 mRNAs diferencialmente expressos, dentre eles 111 super-regulados e 152 sub-regulados. Enquanto no tempo de $36 \mathrm{~h}$ houve uma modulação de 469 mRNAs, destes 230 foram super-regulados e 239 sub-regulados (Figura 22 B). Para a análise do padrão de expressão dos genes diferencialmente expressos um heatmap de agrupamento hierárquico não supervisionado foi elaborado (Figura 23). Com o diagrama de Venn foi possível observar uma interseção de 66 genes modulados em ambos os tempos (Figura 24) (HEBERLE et al., 2015). Os genes com uma modulação expressiva foram destacados na figura 25 .

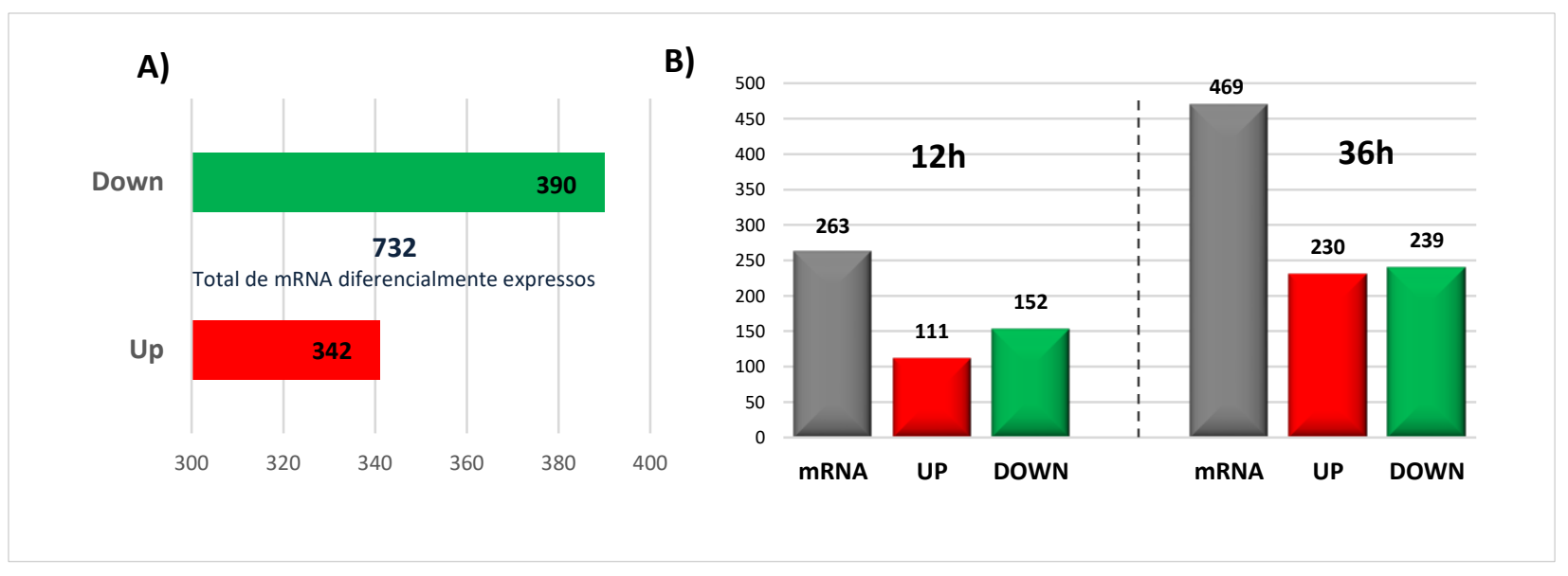

Figura 22 Análise quantitativa dos valores de expressão em células mTEC 3.10E6 Aire KO. (A) Perfil de expressão de mRNAs em células mTEC 3.10E6 Aire KO co-cultivadas com timócitos (B) nos tempos de 12 e 36 horas (fold change $\geq .1 .5$, $p$ value $\leq 0.05$ ). 


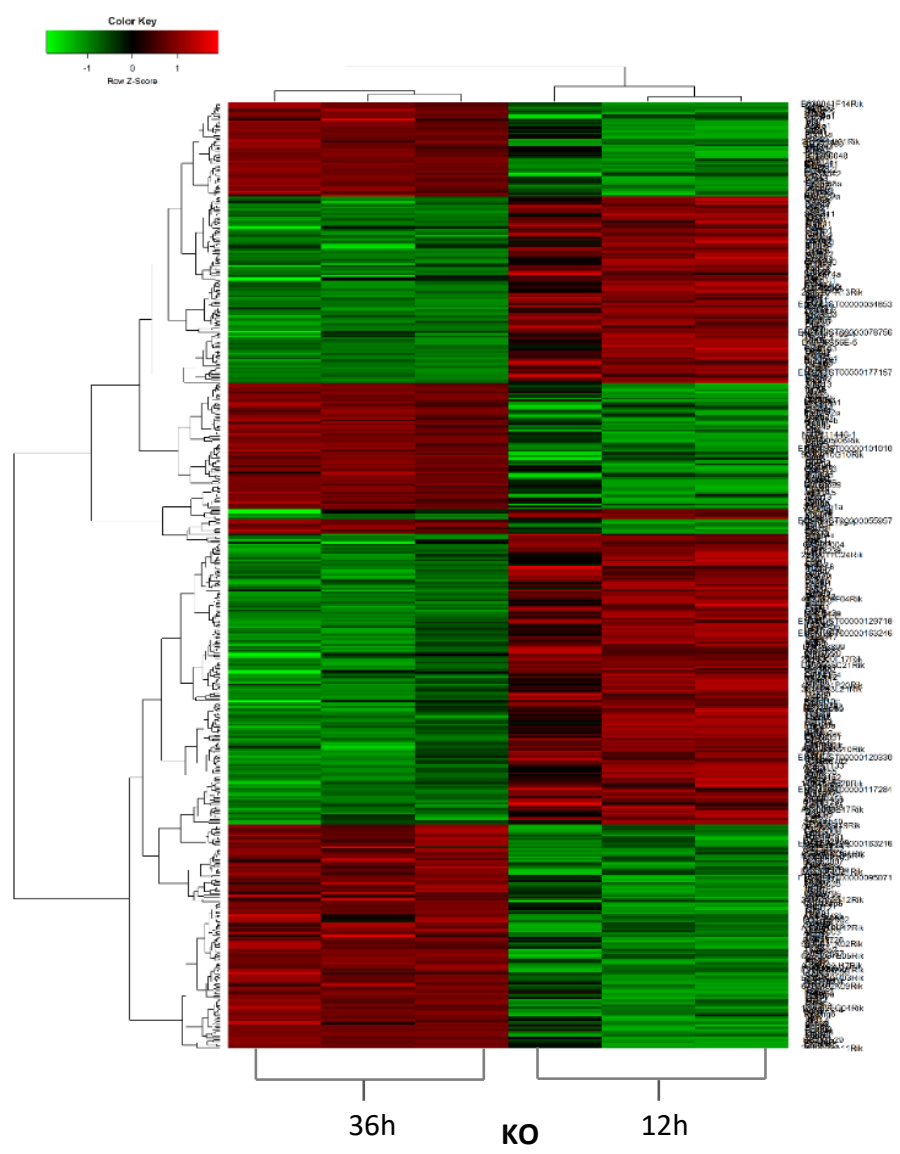

Figura 23 Heatmap do agrupamento hierárquico dos mRNAs modulados nas células mTECs Aire KO (3.10E6) co-cultivadas com timócitos nos tempos de 12 e $36 \mathrm{~h}$ (fold change $\geq .1 .5, \mathrm{p}$ value $\leq 0.05$ ).

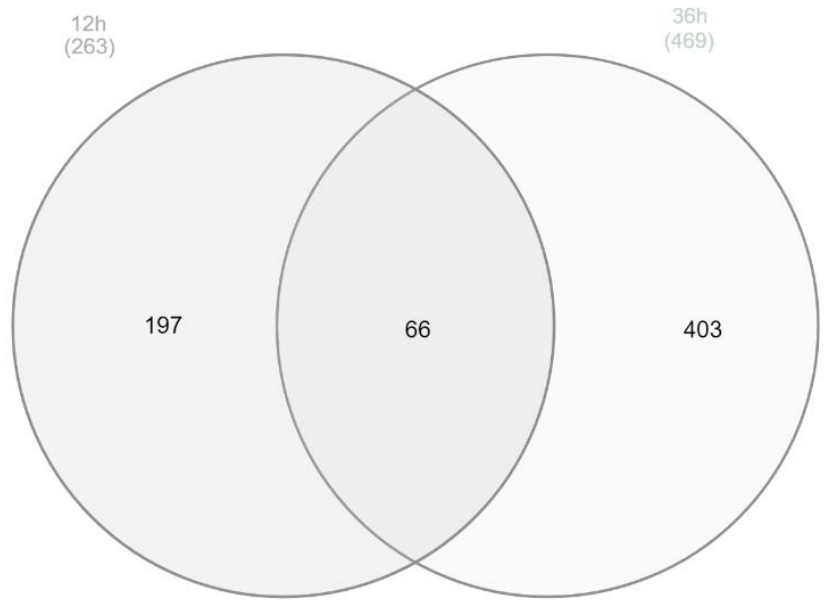

Figura 24 Diagrama de Venn. Representação por diagrama de Venn mostrando 66 genes em comum nos tempos de $12 \mathrm{~h}$ e $36 \mathrm{~h}$ de adesão entre mTECs e timócitos. 


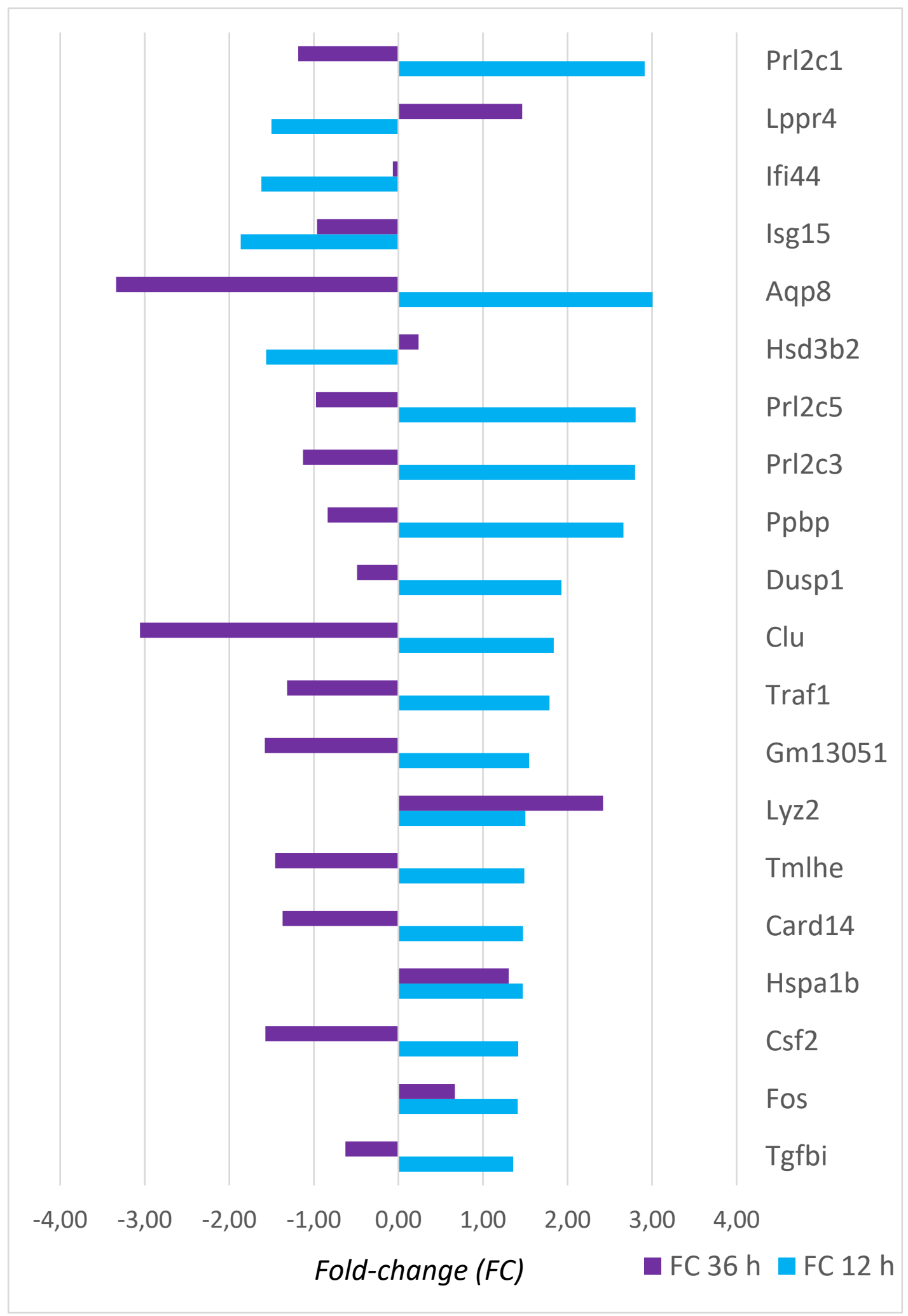

Figura 25 Top genes diferencialmente expressos em mTEC Aire KO (mTEC 3.10E6) co-cultivadas com timócitos. 


\section{Up-regulated genes}

\section{A}

\section{$12 \mathrm{~h}$ adhesion}

Regulation of epithelial to mesenchymal transition

Rositive regulation of $\mathrm{T}$ cell differentiation in thymus

Neutrophil degranulation

Histamine secretion

Regulation of mitotic cell cycle spindle assembly...

Extracellular matrix organization

Regulation of apoptotic process

Response to lipopolysaccharide
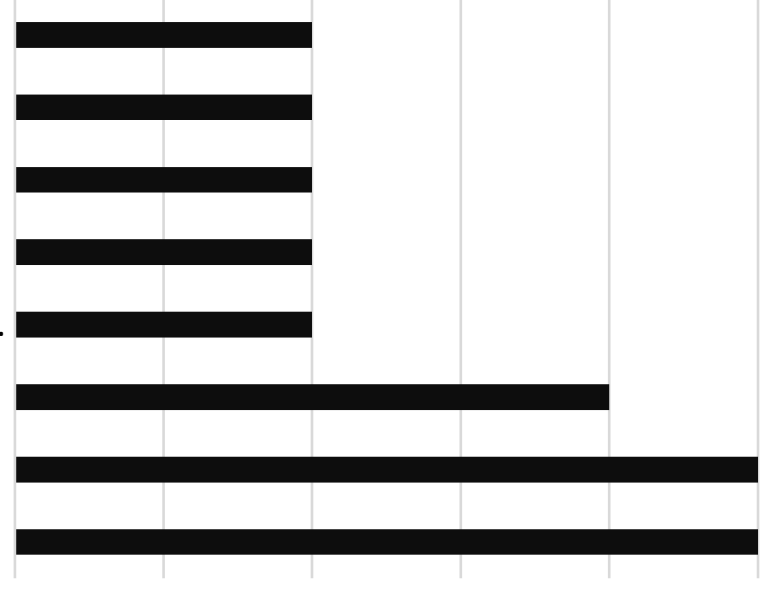

$0 \quad 1$

2

3

\section{6h adhesion}

B

Positive regulation of cell cycle

Cell morphogenesis

Positive regulation of protein phosphorylation Negative regulation of epithelial to mesenchymal transition

Carbohydrate metabolic process

Glutathione metabolic process

Metabolic process

Regulation of cell shape

Lipid metabolic process

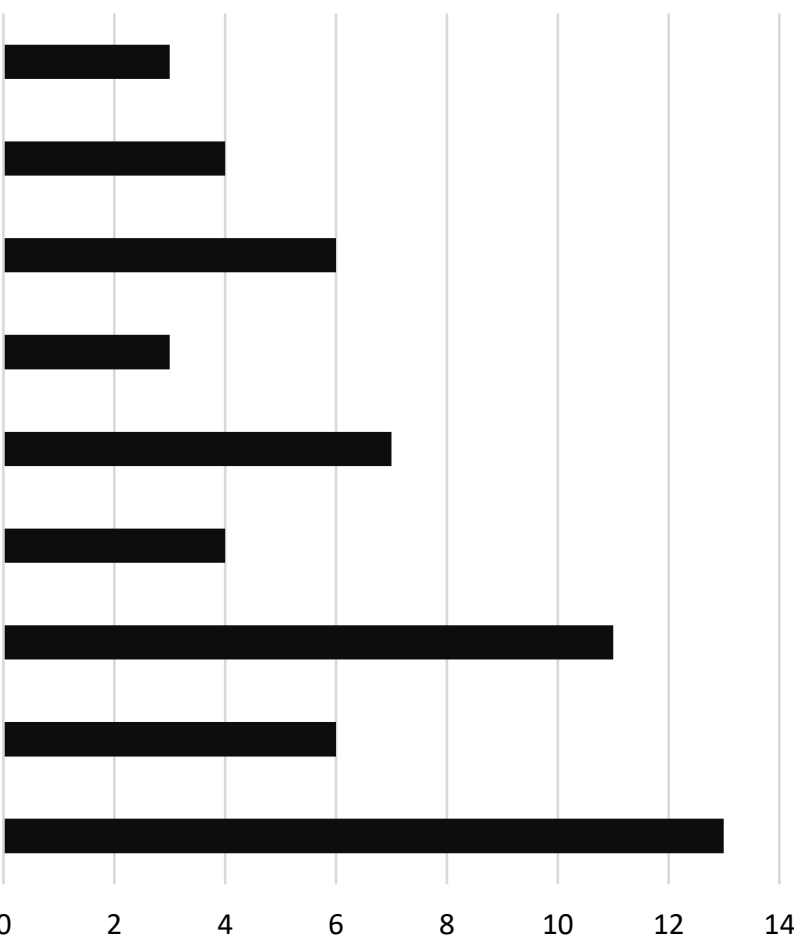


C

\section{Down-regulated genes}

\section{$12 \mathrm{~h}$ adhesion}

Cellular calcium ion homeostasis

Cell surface receptor signaling pathway

Cell adhesion

Positive regulation of synapse assembly

Positive regulation of proteasomal ubiquitindependent protein catabolic process

Adenylate cyclase-inhibiting G-protein coupled receptor signaling pathway

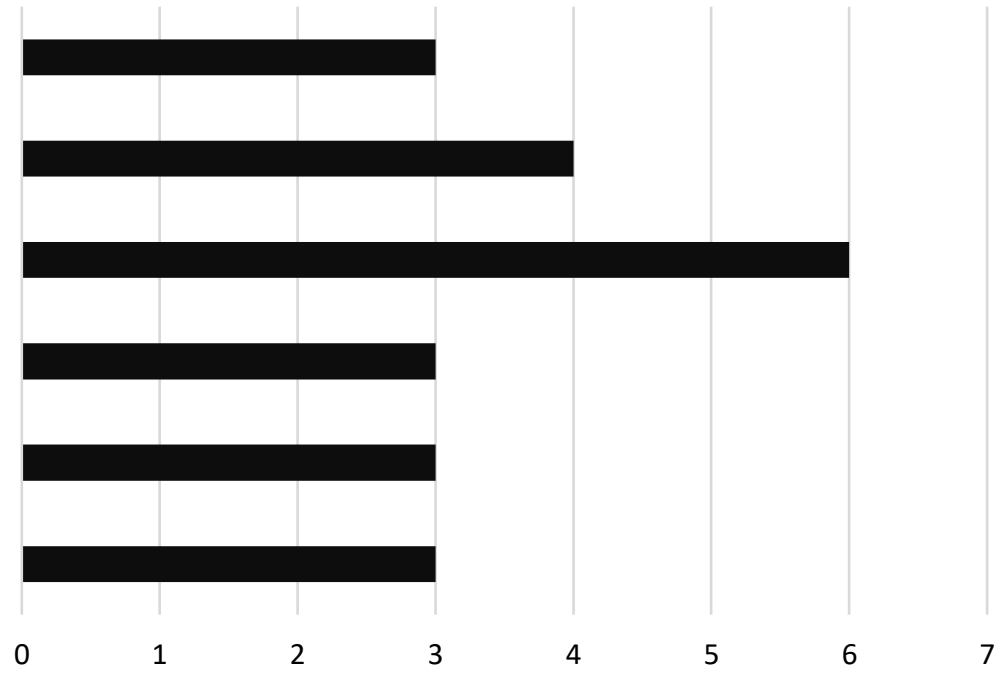

36h adhesion

D

Immune response

Positive regulation of $\mathrm{T}$ cell proliferation

Regulation of cell proliferation

Cellular response to extracellular stimulus

Regulation of cell growth

Cell adhesion

Positive regulation of cell proliferation

Mesenchymal cell differentiation

Positive regulation of transcription from RNA polymerase II promoter

Positive regulation of gene expression

Peptide cross-linking
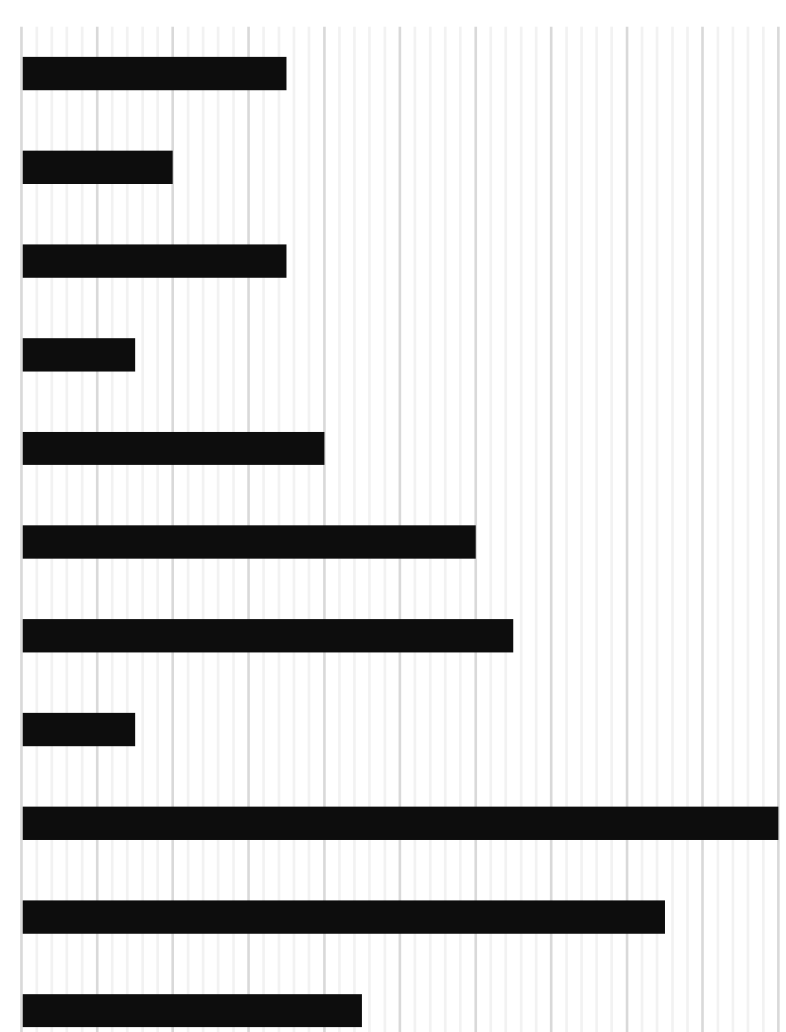

$\begin{array}{llllllllllll}0 & 2 & 4 & 6 & 8 & 10 & 12 & 14 & 16 & 18 & 20 & 22\end{array}$

Figura 26 Análise in silico dos processos biológicos envolvidos nas células mTECs KO para o gene Aire em co-cultivo com timócitos nos tempos de 12 e 36h. (A-D) dos processos biológicos dos genes diferencialmente expressos na condição Aire KO -/-, modulados em co-cultivo com timócitos nos tempos de 12 e 36h (Plataforma DAVID Bioinformatics Resources 6.8 Database, score <0,05). 


\subsection{Caracterização dos IncRNAs diferencialmente expressos em células mTEC 3.10 WT co-cultivadas com timócitos}

$\mathrm{Na}$ análise de transcritos de IncRNA em das células mTEC 3.10 WT foram identificados um total de 109 IncRNAs diferencialmente expressos, dentre os quais 84 sub-regulados e 25 super-regulados (Figura $27 \mathrm{~A}$ ). A análise das mTECs 3.10 co-cultivadas com timócitos no tempo de $12 \mathrm{~h}$ mostrou uma modulação de 34 IncRNAs diferencialmente expressos, sendo destes, 9 superregulados e 25 sub-regulados. Enquanto no tempo de $36 \mathrm{~h}$ houve uma modulação de 73 IncRNA, destes 16 super-regulados e 59 sub-regulados (Figura $27 \mathrm{~B})$.

A)

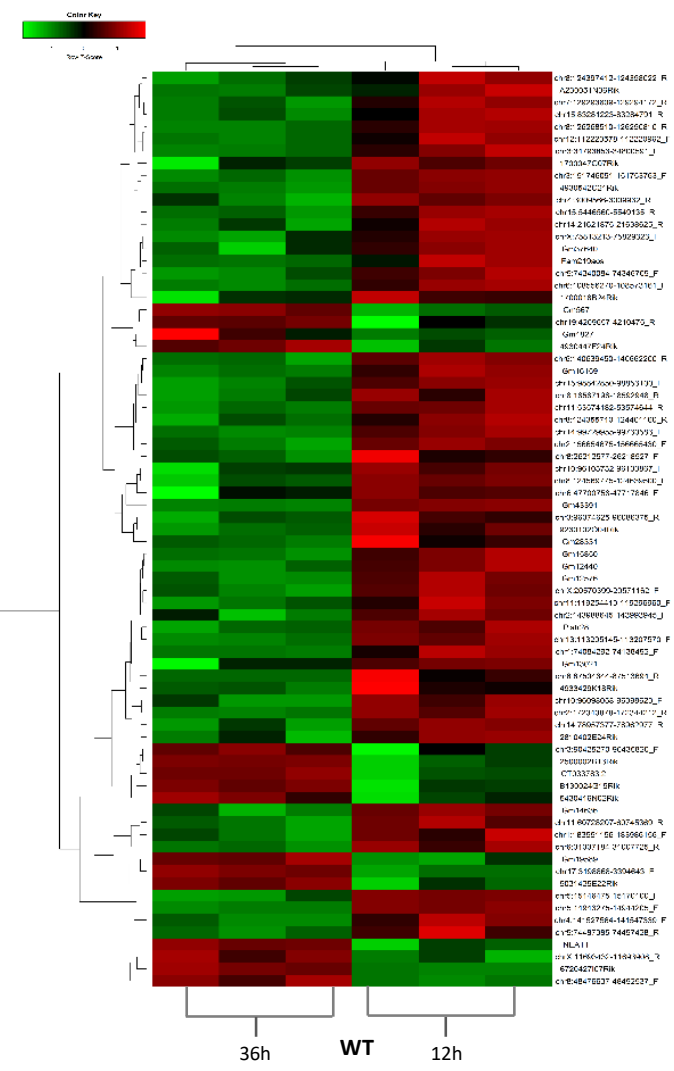

B)
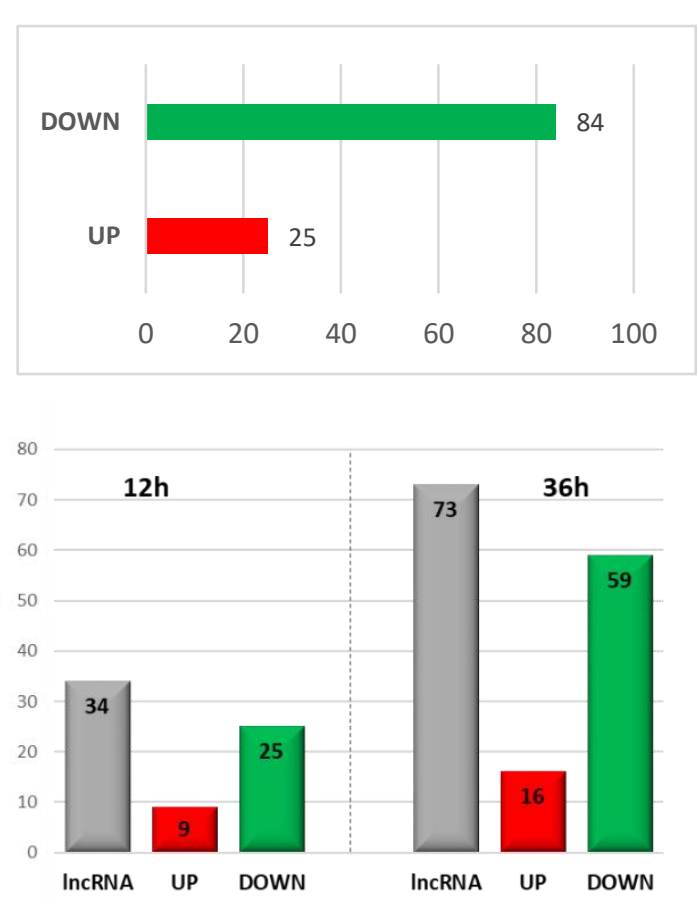

Figura 27 A) Heatmap do agrupamento hierárquico não supervisionado dos IncRNAs modulados nas células mTEC 3.10 (WT) co-cultivadas com timócitos (fold change $\geq .1 .5, p$ value $\leq 0.05$ ) B) Perfil de expressão de mRNAs em células mTEC 3.10E6 Aire KO co-cultivadas com timócitos nos tempos de 12 e 36 horas (fold change $\geq .1 .5$, p value $\leq 0.05$ ). 


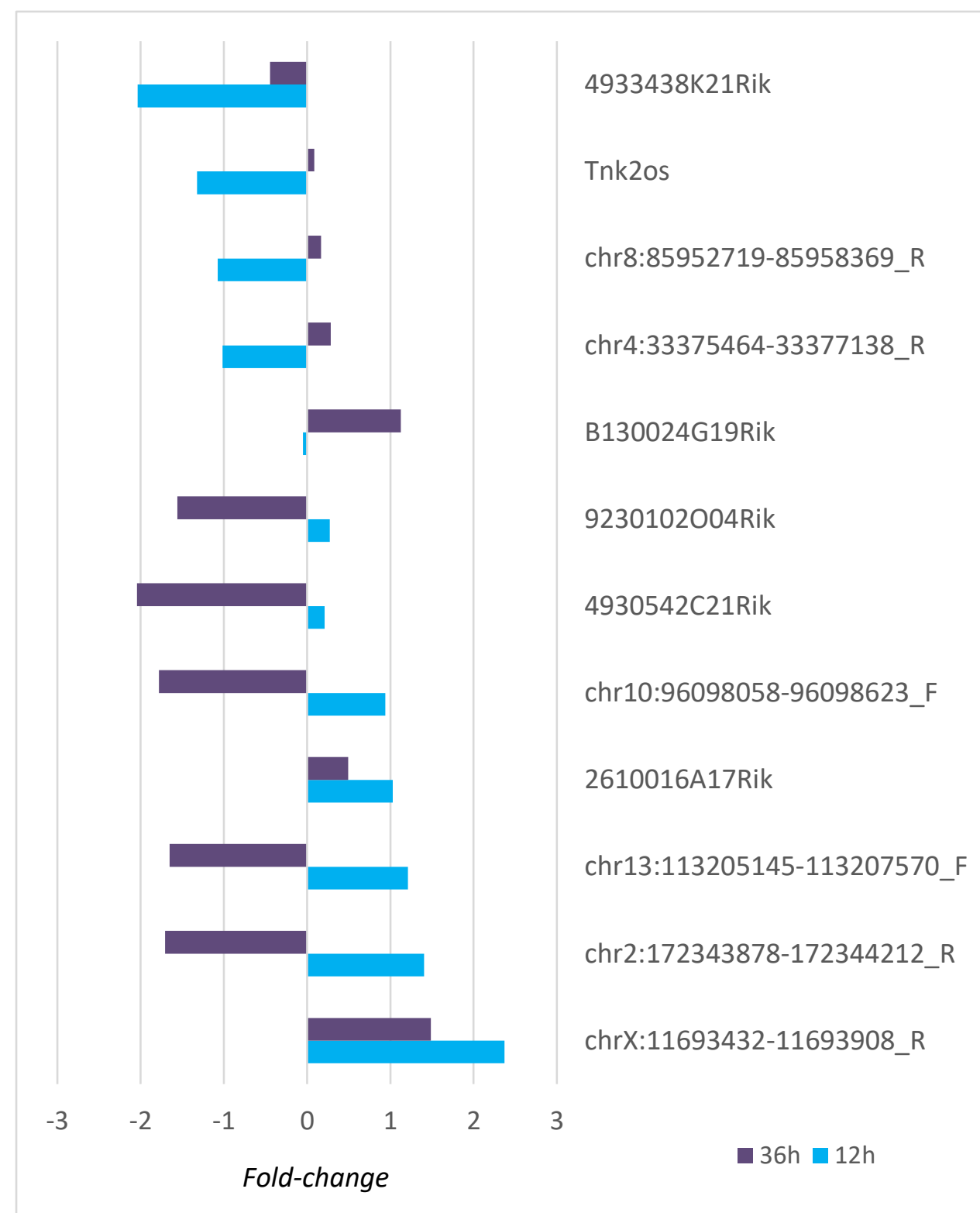

Figura 28 Top RNAs longos não codificantes (IncRNAs) diferencialmente expressos em mTEC 3.10 WT co-cultivadas com timócitos. 


\subsection{Análise dos IncRNAs em células mTEC 3.10E6 Aire KO co-cultivadas com timócitos}

Foram identificados um total de 116 IncRNAs diferencialmente expressos nas células mTEC 3.10E6 (Aire KO), dentre os quais 86 sub-regulados e 30 super-regulados (Figura $25 \mathrm{~A}$ ). A análise das células mTEC 3.10E6 co-cultivadas com timócitos no tempo de $12 \mathrm{~h}$ mostrou uma modulação de 43 IncRNAs, dentre os quais 11 super-regulados e 32 sub-regulados. Enquanto que no tempo de $36 \mathrm{~h}$ houve modulação de 73 IncRNAs, dentre esses 19 super-regulados e 54 subregulados (Figura $24 \mathrm{~B}$ ).
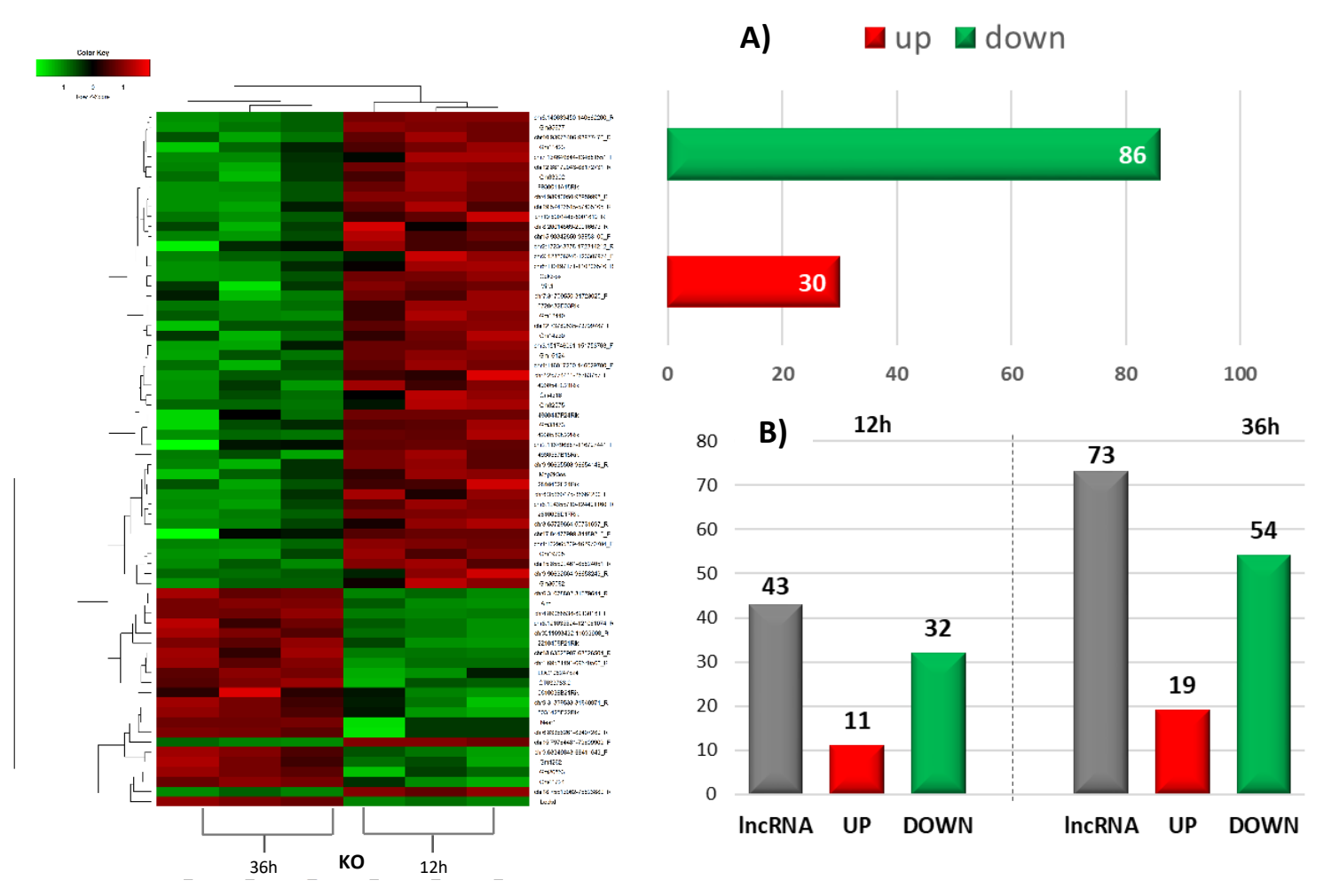

Figura 29 A) Heatmap do agrupamento hierárquico não supervisionado dos IncRNAs modulados nas células mTEC 3.10E6 (Aire KO) co-cultivadas com timócitos (fold change $\geq .1 .5, p$ value $\leq 0.05$ ) B) Perfil de expressão de IncRNAs em células mTEC $3.10 \mathrm{KO}$ para o gene Aire co-cultivadas com timócitos nos tempos de 12 e 36 horas (fold change $\geq .1 .5$, $p$ value $\leq 0.05$ ). 


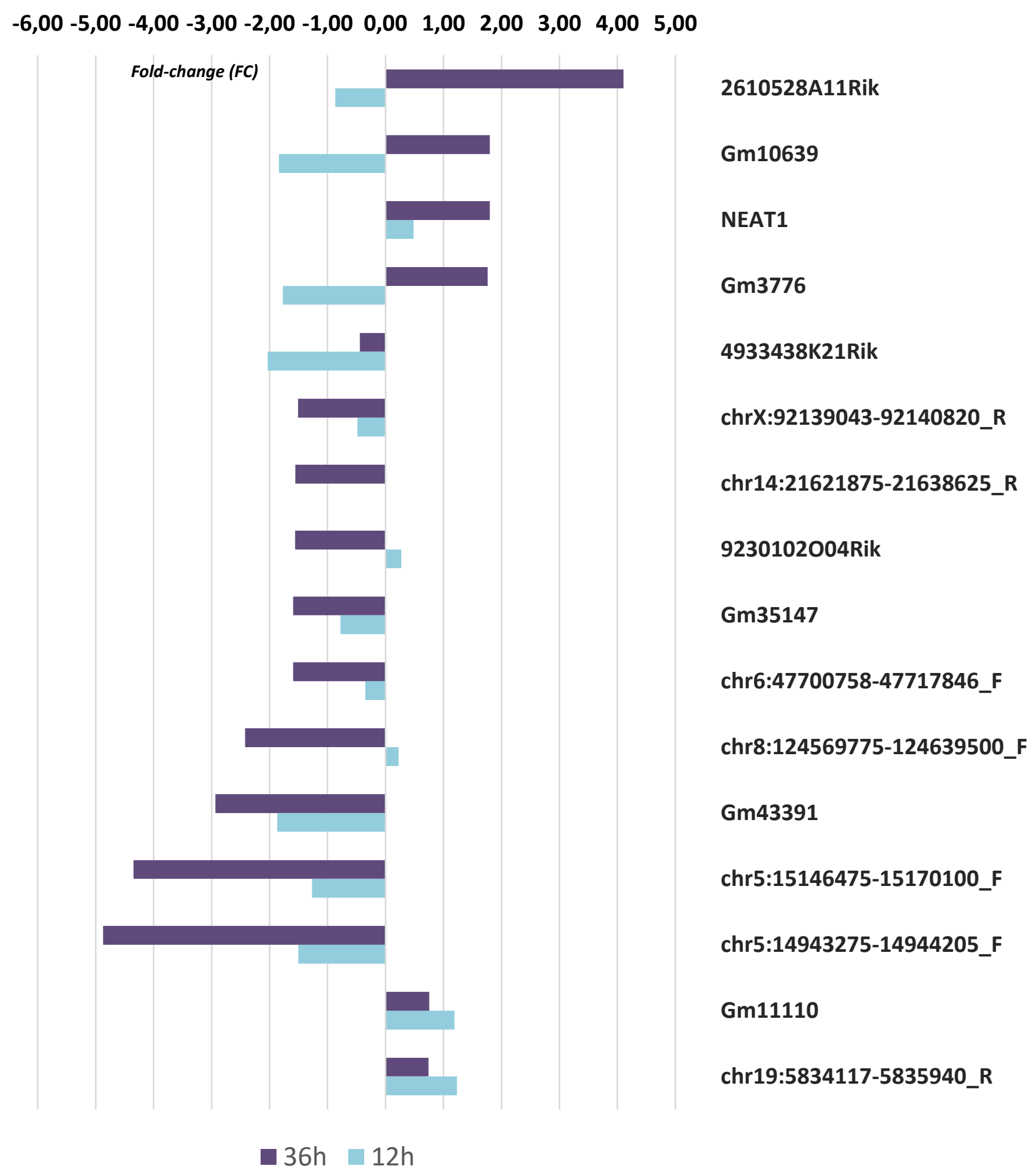

Figura 30 Top RNAs longo não codificantes (IncRNAs) diferencialmente expressos em células mTEC 3.10E6 (Aire KO) co-cultivadas com timócitos. 
8.9. Classificação dos IncRNAs modulados em células mTEC 3.10 WT e mTEC 3.10E6 (Aire KO) co-cultivadas com timócitos

A)

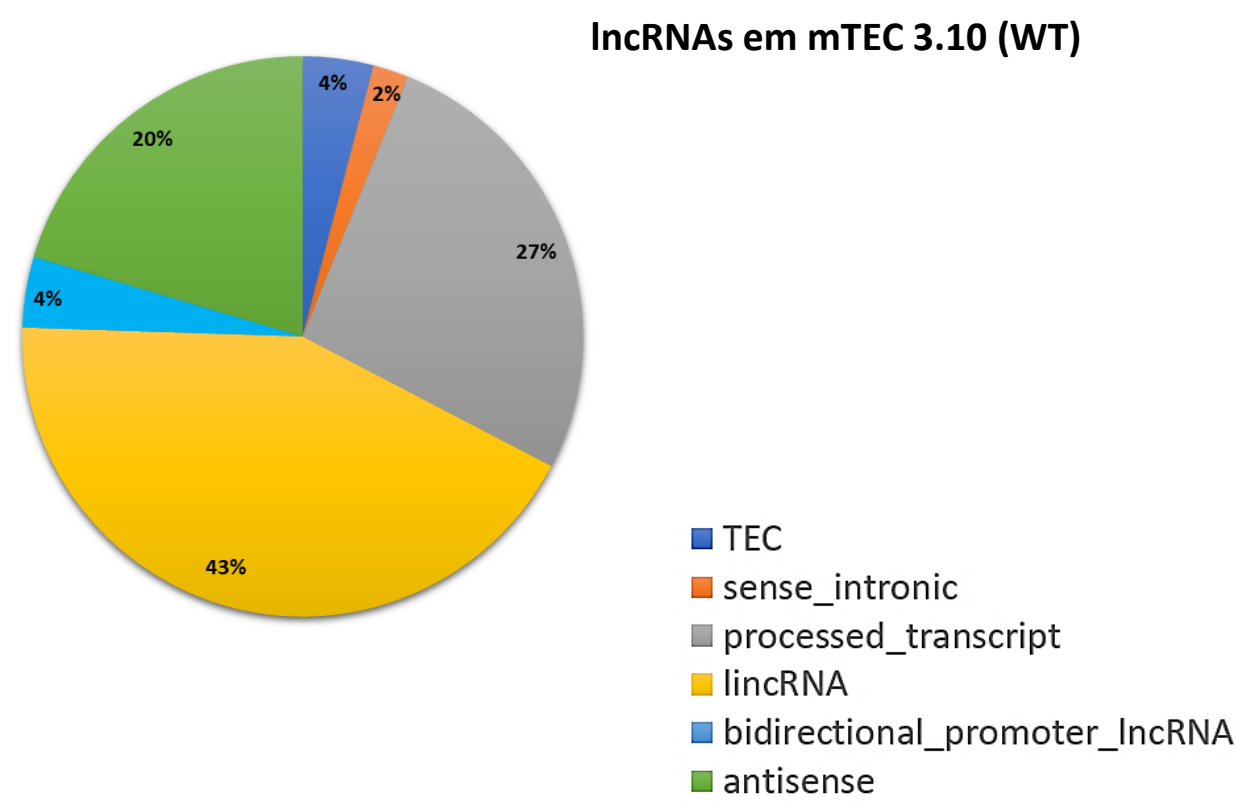

B)

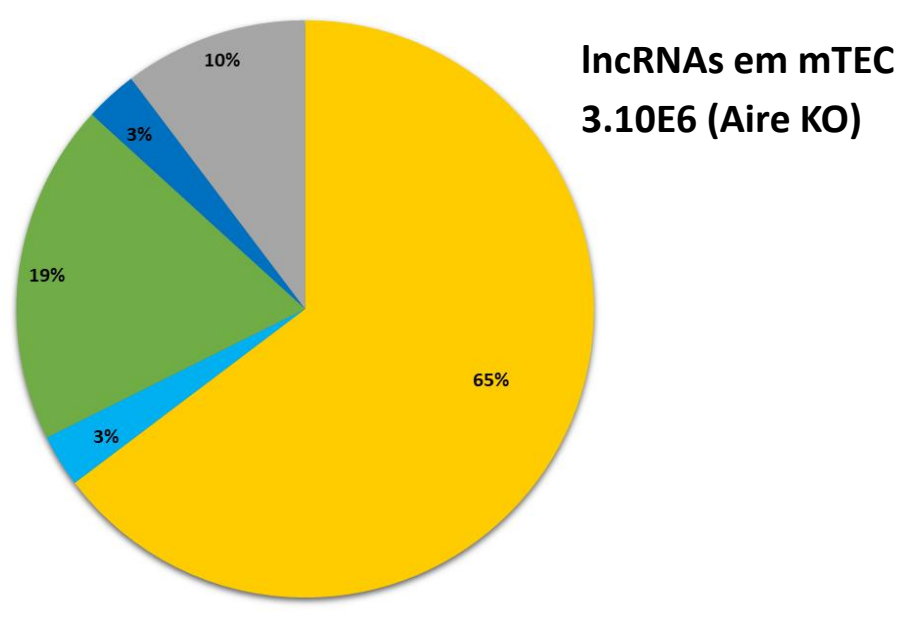

Figura 31 Classificação e distribuição e dos IncRNAs modulados nas células mTEC 3.10 WT (A) e mTEC 3.10E6 (Aire KO) (B) co-cultivadas com timócitos.. 


\subsection{Distribuição genômica dos IncRNAs diferencialmente expressos}

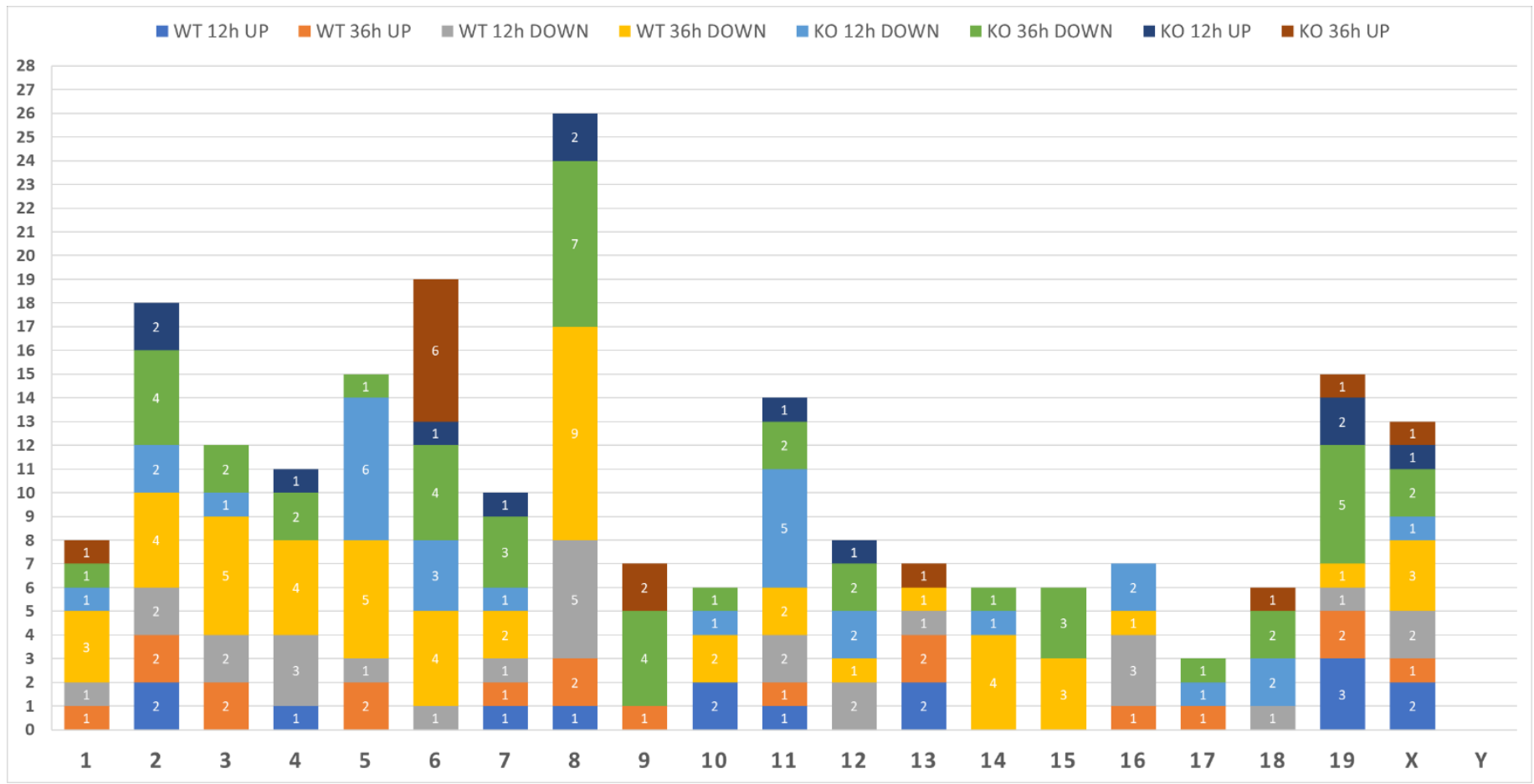

Figura 32 Painel geral da localização cromossômica dos IncRNAs. Distribuição dos IncRNAs diferencialmente expressos ao longo do genoma do camundongo (GRCm38.p6 Genome Reference Consortium Mouse Build 38 patch release 6 - Organism: Mus musculus) - (Apêndice 1)

\subsection{Identificação e posicionamento dos genes codificadores mais próximos}

Tabela 1 Genes codificantes mais próximo do LncRNA. Análise dos IncRNAs e seus vizinhos codificadores mais próximos. Cálculo realizado pela ferramenta Biomart na plataforma R. Distância em pares de base (pb).

\section{Genes codificantes mais próximos}

LncRNA

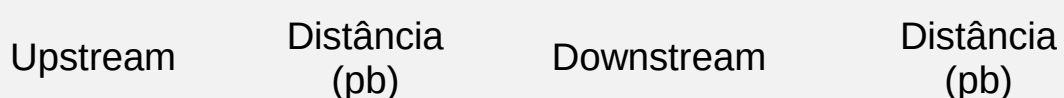

$\begin{array}{lcccc}\text { Airn } & \text { Igf2r } & 28353 & \text { Mas1 } & 126832 \\ \text { BC051226 } & \text { Platr17 } & 4074 & \text { Daxx } & 205 \\ \text { Cep83os } & \text { Tmcc3 } & 376627 & \text { Cep83 } & 78 \\ \text { Fam219aos } & \text { 1110017D15Rik } & 9683 & \text { Fam219a } & 52072 \\ \text { Gm10069 } & \text { Fkbp4 } & 80 & \text { Pzp } & 87963\end{array}$




\begin{tabular}{|c|c|c|c|c|}
\hline Gm10451 & Ppp1r36 & 26959 & Plekhg3 & 86394 \\
\hline Gm11033 & Large1 & 1480380 & IsX & 39253 \\
\hline Gm11110 & Tubb4a & 18140 & Tnfsf9 & 597 \\
\hline Gm11496 & Coil & 26292 & Trim25 & 2832 \\
\hline Gm12440 & $\mathrm{Hao} 2$ & 156583 & Wars2 & 91246 \\
\hline Gm12576 & Heatr6 & 95797 & Hnf1b & 570 \\
\hline Gm13021 & Igsf21 & 175740 & Arhgef10l & 243488 \\
\hline Gm14005 & $\mathrm{Bcl} 2 \mathrm{I} 11$ & 303327 & Spdye4c & 161843 \\
\hline Gm14636 & 4930578C19Rik & 705861 & Tex13c3 & 314087 \\
\hline Gm15226 & Egfl6 & 35822 & Tmsb4x & 587773 \\
\hline Gm15850 & Cacna1s & 78433 & Kif21b & 206 \\
\hline Gm16062 & Flcn & 369 & Cops3 & 8607 \\
\hline Gm16159 & Fgfr1 & 42429 & Letm2 & 41430 \\
\hline Gm19557 & $\operatorname{Stn} 1$ & 24137 & Slk & 66696 \\
\hline Gm19589 & Glrp1 & 41451 & Arl4c & 150359 \\
\hline Gm19705 & Zfp281 & 45868 & $\mathrm{Nr} 5 \mathrm{a} 2$ & 289679 \\
\hline Gm20324 & Tcf20 & 13054 & Nfam1 & 134226 \\
\hline Gm20753 & Zcchc2 & 181118 & Phlpp1 & 228 \\
\hline Gm26708 & Abhd17c & 247 & Arnt2 & 257979 \\
\hline Gm28331 & Gm20824 & 417985 & Gm20815 & 159277 \\
\hline Gm37640 & Gnb4 & 5724 & Actl6a & 95437 \\
\hline Gm4262 & Litaf & 15777 & Snn & 52047 \\
\hline Gm4316 & Sult5a1 & 6985 & Dpep1 & 20987 \\
\hline Gm43391 & Gm17019 & 431173 & Gm21149 & 12352 \\
\hline Gm43672 & Agtr1b & 1708965 & Tbl1xr1 & 510 \\
\hline Gm4425 & Ywhaq & 739009 & Gm10330 & 1623619 \\
\hline Gm45326 & Lsm6 & 132774 & Zfp827 & 74523 \\
\hline Gm567 & Рpp3ca & 619515 & Emcn & 51428 \\
\hline Gm6507 & Tpra1 & 283774 & Plxna1 & 176595 \\
\hline Igf1os & Pah & 306567 & $\operatorname{lgf1}$ & 29903 \\
\hline Kcnq1ot1 & Kcnq1 & 190187 & Cdkn1c & 164447 \\
\hline Map2k3os & Natd1 & 18055 & Map2k3 & 166 \\
\hline Mir22hg & Wdr81 & 7101 & Tlcd2 & 176 \\
\hline Mirg & Rtl1 & 129434 & Dio3 & 549304 \\
\hline Mirt1 & Smndc1 & 63521 & Dusp5 & 75015 \\
\hline Neat1 & Scyl1 & 74077 & Frmd8 & 29796 \\
\hline Peg13 & Trappc9 & 245486 & Chrac1 & 280068 \\
\hline Platr28 & Rbmxl2 & 33577 & Syt9 & 127706 \\
\hline Snhg14 & Ube3a & 95399 & Gm38393 & 680915 \\
\hline Snord65 & Trpv2 & 30029 & Lrrc75a & 44008 \\
\hline Tnk2os & Tnk2 & 24323 & Muc4 & 67689 \\
\hline 0610009L18Rik & Actg1 & 136 & Fscn2 & 12856 \\
\hline 0610038B21Rik & Arhgap10 & 897 & Prmt9 & 32351 \\
\hline 1110002L01Rik & Kif3c & 61879 & Asxl2 & 154 \\
\hline 1700030M09Rik & 1700018B08Rik & 2428 & Fbxo31 & 34424 \\
\hline 1700047G07Rik & Got2 & 623793 & Cdh8 & 2904087 \\
\hline
\end{tabular}




\begin{tabular}{lcccc} 
1700080N15Rik & Frmd4a & 123424 & Prpf18 & 510945 \\
\hline 1700092C10Rik & Stc1 & 142619 & Nkx2-6 & 55 \\
1700112J16Rik & Adamts17 & 382723 & Lysmd4 & 86 \\
\hline 1700120G07Rik & Fam196a & 257697 & Nps & 62701 \\
\hline 1700120K04Rik & Rnf40 & 15678 & Zfp629 & 9988 \\
\hline 1810019D21Rik & Esrp2 & 1574 & Pla2g15 & 14999 \\
\hline 2500002B13Rik & Sap30 & 194 & Hmgb2 & 23853 \\
2610016A17Rik & Dmrt3 & 61702 & Dmrt2 & 181 \\
\hline 2610035D17Rik & Sox9 & 390853 & Slc39a11 & 392679 \\
\hline 2810402E24Rik & Usp54 & 54 & Myoz1 & 15531 \\
\hline 3300005D01Rik & Zdhhc14 & 306100 & Snx9 & 42672 \\
\hline 4930447F24Rik & Bsn & 56666 & Dag1 & 130240 \\
\hline 4930447K03Rik & Tubb2a & 35265 & Tubb2b & 17082 \\
\hline 4933405E24Rik & P4ha2 & 113190 & Csf2 & 36382 \\
\hline 4933438K21Rik & Rex2 & 46586 & Zfp991 & 63602 \\
5031425E22Rik & Lhfpl3 & 687265 & Kmt2e & 1117 \\
\hline 5430416N02Rik & Sec31a & 50622 & Lin54 & 71104 \\
\hline 5730405O15Rik & Med14 & 279942 & Usp9x & 29483 \\
\hline 5730419F03Rik & Mogat1 & 98339 & Acsl3 & 48317 \\
\hline 6720427I07Rik & A830005F24Rik & 24252 & Ptpdc1 & 87842 \\
\hline 9230102O04Rik & 4930412O13Rik & 2741 & Taf3 & 69664 \\
\hline 9330151L19Rik & Gm49384 & 7056 & Pole2 & 7246 \\
\hline 9430078K24Rik & Rad51b & 627451 & Zfp36l1 & 188280 \\
\hline 9530014B07Rik & Msx2 & 166119 & Drd1 & 416512 \\
\hline 9930014A18Rik & Fam84b & 2809 & A1bg & 96992 \\
\hline A130077B15Rik & Avpr1a & 121392 & Ppm1h & 241556 \\
\hline A530017D24Rik & Ulk2 & 12985 & Akap10 & 62194 \\
\hline A730017L22Rik & 4930402H24Rik & 66222 & Atrn & 139 \\
\hline B130024G19Rik & Nr2f2 & 4317 & Gm10295 & 986575 \\
B230206L02Rik & Spag9 & 137394 & Tob1 & 77969 \\
D930048N14Rik & N4bp3 & 112 & 0610009B22Rik & 37699 \\
Xist & Gm26992 & 61244 & Zcchc13 & 147332 \\
Neat1 & Scyl1 & 74077 & Frmd8 & 29796
\end{tabular}




\subsection{Avaliação do potencial codificador dos IncRNAs diferencialmente expressos}

Tabela 2 LncRNAs e seu potencial codificador. Potencial codificador de cada IncRNA calculado pela ferramenta Coding Potential Calculator 2-CPC2. (PC- Potencial Codificador). Tabela completa no Apêndice 2.

\begin{tabular}{|c|c|c|}
\hline \multirow[t]{2}{*}{ LncRNA } & \multicolumn{2}{|c|}{$\begin{array}{l}\text { Coding Potential Calculator } 2 \\
\text { (CPC2) }\end{array}$} \\
\hline & Score & PC \\
\hline chr1:135830093-135840837_F & 0.0154964 & NC \\
\hline chr1:135956616-135957485_R & 0.00676454 & NC \\
\hline chr1:162965309-162970704_F & 0.00516844 & NC \\
\hline chr1:183811267-183816309_F & 0.0597192 & NC \\
\hline chr8:59966759-59989065_R & 0.0061802 & NC \\
\hline chr9:102891041-102907200_F & 0.00515525 & NC \\
\hline chrX:11693432-11693908_R & 0.00379968 & NC \\
\hline chrX:123306246-123307974_F & 0.0766146 & NC \\
\hline Gm11033 & 0.0224776 & NC \\
\hline Gm16159 & 0.0252371 & NC \\
\hline Mir22hg & 0.0323014 & NC \\
\hline Airn & 0.097855 & NC \\
\hline Gm14005 & 0.0159236 & NC \\
\hline Platr28 & 0.0305438 & NC \\
\hline Mirg & 0.029091 & NC \\
\hline Neat1 & 0.0812413 & NC \\
\hline BC051226 & 0.0939098 & NC \\
\hline Gm6507 & 0.232186 & NC \\
\hline Gm12576 & 0.427106 & NC \\
\hline BC051226 & 0.115421 & NC \\
\hline Gm11110 & 0.301507 & NC \\
\hline Gm13021 & 0.0224875 & NC \\
\hline Mirt1 & 0.0207367 & NC \\
\hline Tnk2os & 0.54231 & C \\
\hline Gm19705 & 0.0362795 & NC \\
\hline Snord65 & 0.0338885 & NC \\
\hline Xist & 0.752728 & C \\
\hline Gm15850 & 0.0541872 & NC \\
\hline
\end{tabular}




\subsection{Rede de interação entre os IncRNAs e seus alvos (mRNAs) em células mTEC 3.10 (WT)}

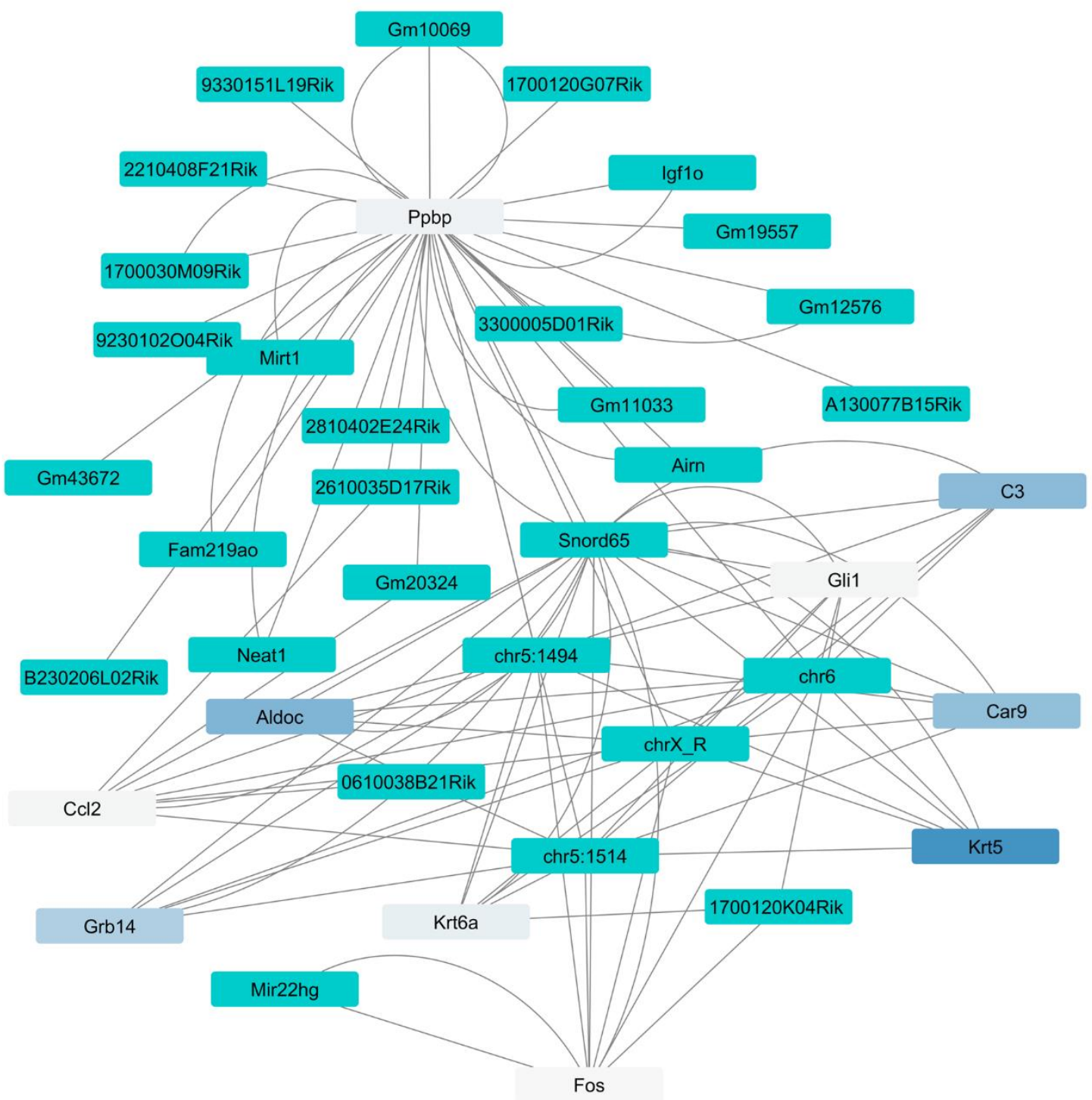

Figura 33 Rede de interação entre IncRNAs e mRNAs alvos em células mTEC 3.10 WT. LncRNAs e seus mRNAs codificares alvos, preditos por meio da análise da energia livre de interação normalizada (ndG) utilizando a ferramenta LncTar (LI et al., 2014). Foram selecionados os top IncRNAs e os mRNAs diferencialmente expressos para a montagem da rede. Os IncRNAs estão representados em verde ciano e os mRNAs em azul (a tonalidade mais forte representa ndG alta). 
Tabela 3 mRNAs alvos dos IncRNAs preditos pela ferramenta LncTar. Lista dos IncRNAs e seus mRNAs alvos de interação de acordo com a energia livre ligação normalizada (ndG).

\begin{tabular}{|c|c|c|}
\hline LncRNA & Genes alvos & ndG \\
\hline \multirow{10}{*}{ chr5:14943275-14944205_F } & Car9 & -0.8167 \\
\hline & Krt6a & -0.2551 \\
\hline & Grb14 & -0.2493 \\
\hline & Ppbp & -0.2379 \\
\hline & Fos & -0.6047 \\
\hline & $\mathrm{C} 3$ & -0.1965 \\
\hline & Aldoc & -0.1598 \\
\hline & $\mathrm{Ccl} 2$ & -0.176 \\
\hline & Krt5 & -0.2621 \\
\hline & Gli1 & -0.4413 \\
\hline \multirow{10}{*}{ chr5:15146475-15170100_F } & Car9 & -0.1918 \\
\hline & Krt6a & -0.2469 \\
\hline & Grb14 & -0.2022 \\
\hline & Ppbp & -0.202 \\
\hline & Fos & -0.1924 \\
\hline & C3 & -0.2326 \\
\hline & Aldoc & -0.1788 \\
\hline & $\mathrm{Ccl} 2$ & -0.1242 \\
\hline & Krt5 & -0.3459 \\
\hline & Gli1 & -0.2521 \\
\hline \multirow{10}{*}{ chr6:47700758-47717846_F } & Car9 & -0.4936 \\
\hline & Krt6a & -0.2804 \\
\hline & Grb14 & -0.3411 \\
\hline & Ppbp & -0.2079 \\
\hline & Fos & -0.1679 \\
\hline & $\mathrm{C} 3$ & -0.5128 \\
\hline & Aldoc & -0.2367 \\
\hline & Ccl2 & -0.3735 \\
\hline & Krt5 & -0.2938 \\
\hline & Gli1 & -0.273 \\
\hline \multirow{10}{*}{ chrX:92139043-92140820_R } & Car9 & -0.1817 \\
\hline & Krt6a & -0.1968 \\
\hline & Grb14 & -0.143 \\
\hline & Ppbp & -0.84 \\
\hline & Fos & -0.3954 \\
\hline & C3 & -0.1598 \\
\hline & Aldoc & -0.2228 \\
\hline & $\mathrm{Ccl} 2$ & -0.1224 \\
\hline & Krt5 & -0.2276 \\
\hline & Gli1 & -0.1963 \\
\hline Fam219ao & Ppbp & -0.1104 \\
\hline $\operatorname{lgf10}$ & Ppbp & -0.1008 \\
\hline Mirt1 & Ppbp & -0.1052 \\
\hline Gm10069 & Ppbp & -0.1057 \\
\hline Gm12576 & Ppbp & -0.1299 \\
\hline Airn & Ppbp & -0.1189 \\
\hline
\end{tabular}




\begin{tabular}{|c|c|c|}
\hline Neat1 & Ppbp & -0.106 \\
\hline Gm11033 & Ppbp & -0.1209 \\
\hline Mir22hg & Fos & -0.1204 \\
\hline Fam219ao & Ppbp & -0.1104 \\
\hline $\operatorname{lgf10}$ & Ppbp & -0.1008 \\
\hline Mirt1 & Ppbp & -0.1052 \\
\hline Gm10069 & Ppbp & -0.1057 \\
\hline Gm12576 & Ppbp & -0.1299 \\
\hline Airn & Ppbp & -0.1189 \\
\hline Neat1 & Ppbp & -0.106 \\
\hline Gm11033 & Ppbp & -0.1209 \\
\hline Mir22hg & Fos & -0.1204 \\
\hline \multirow{10}{*}{ Snord65 } & Car9 & -0.1843 \\
\hline & Krt6a & -0.2912 \\
\hline & Grb14 & -0.1598 \\
\hline & Ppbp & -0.1658 \\
\hline & Fos & -0.2683 \\
\hline & $\mathrm{C} 3$ & -0.1895 \\
\hline & Aldoc & -0.1991 \\
\hline & $\mathrm{Ccl} 2$ & -0.1742 \\
\hline & Krt5 & -0.2491 \\
\hline & Gli1 & -0.2986 \\
\hline Gm43672 & Ppbp & -0.1058 \\
\hline \multirow{2}{*}{ Gm20324 } & Ppbp & -0.1134 \\
\hline & Ccl2 & -0.101 \\
\hline Gm19557 & Ppbp & -0.1013 \\
\hline Gm10069 & Ppbp & -0.1057 \\
\hline 3300005D01Rik & Ppbp & -0.1035 \\
\hline \multirow{2}{*}{ 2610035D17Rik } & Ppbp & -0.1146 \\
\hline & $\mathrm{Ccl} 2$ & -0.1046 \\
\hline 2210408F21Rik & Ppbp & -0.1018 \\
\hline B230206L02Rik & Ppbp & -0.1142 \\
\hline 1700030M09Rik & Ppbp & -0.1047 \\
\hline 9230102O04Rik & Ppbp & -0.1164 \\
\hline 0610038B21Rik & Ccl2 & -0.1033 \\
\hline A130077B15Rik & Ppbp & -0.103 \\
\hline \multirow{2}{*}{ 1700120G07Rik } & Ppbp & -0.1046 \\
\hline & Krt6a & -0.1132 \\
\hline \multirow[b]{2}{*}{ 1700120K04Rik } & Fos & -0.1011 \\
\hline & Gli1 & -0.1032 \\
\hline 2810402E24Rik & Ppbp & -0.104 \\
\hline 1700030M09Rik & Ppbp & -0.1047 \\
\hline 9330151L19Rik & Ppbp & -0.1083 \\
\hline
\end{tabular}




\subsection{Rede de interação entre IncRNAs e mRNAs alvos em células mTEC 3.10E6 (Aire KO)}

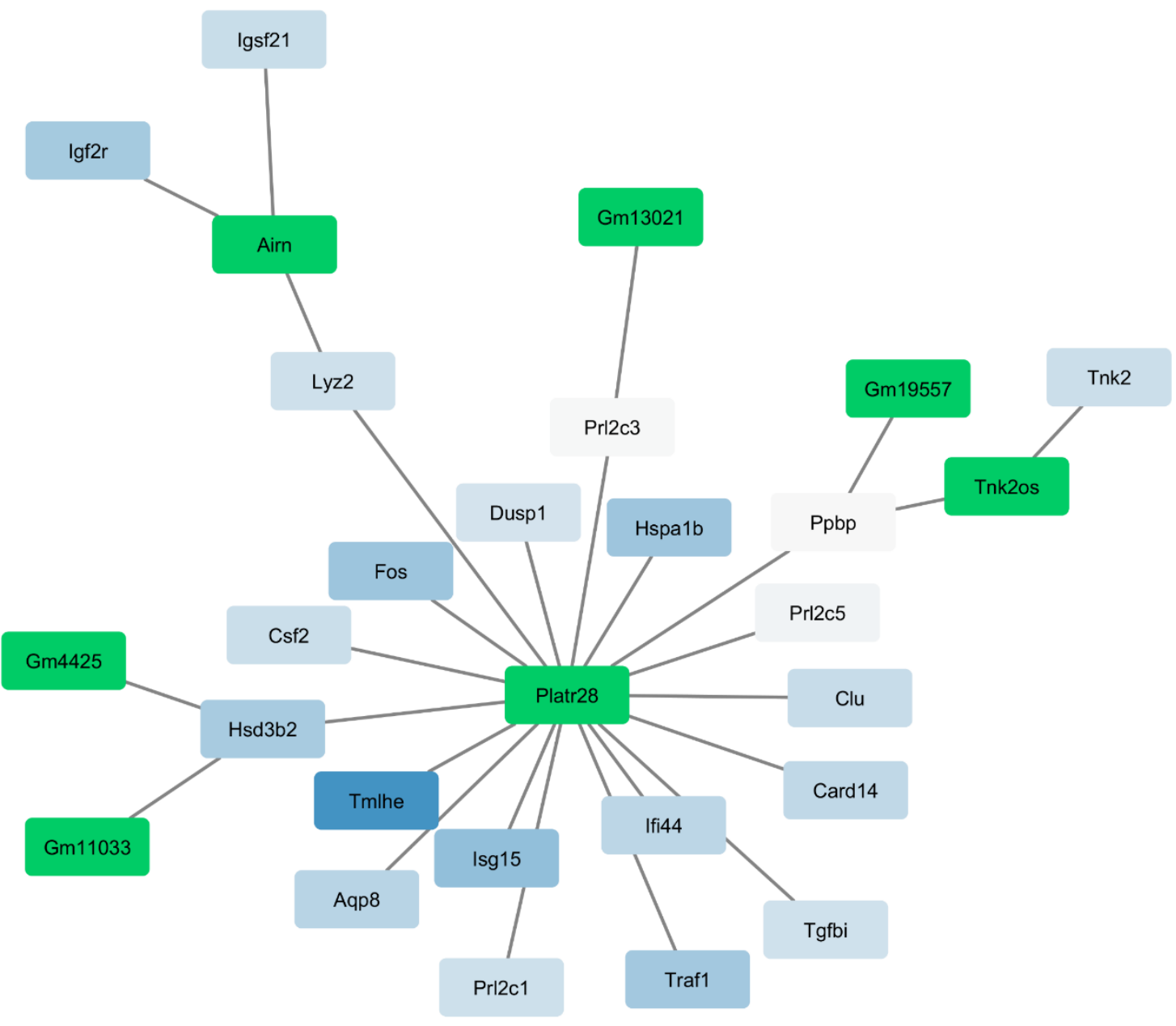

Figura 34 Rede de interação entre IncRNAs e mRNAs alvo. LncRNAs diferencialmente expressos em células mTEC 3.10E6 (Aire KO) e seus mRNAs codificadores alvos, preditos por meio da análise da energia livre de interação normalizada (ndG) utilizando a ferramenta LncTar (LI et al., 2014). Foram selecionados os top IncRNAs e top mRNAs diferencialmente expressos para a montagem da rede. Os IncRNAs estão representados em verde e os mRNAs alvo em azul (a tonalidade mais forte representa ndG alta). 
Tabela 4 mRNAs alvos dos IncRNAs preditos pela ferramenta LncTar. Lista dos IncRNA e seus mRNAs alvos de interação de acordo com a energia livre ligação normalizada (ndG).

\begin{tabular}{|c|c|c|}
\hline LncRNA & Genes alvos & ndG \\
\hline Gm4425 & Hsd3b2 & -0.1897 \\
\hline \multirow{2}{*}{ Tnk2os } & Tnk2 & -0.1937 \\
\hline & Ppbp & -0.195 \\
\hline Gm11033 & Hsd3b2 & -0.1956 \\
\hline \multirow{18}{*}{ Platr28 } & Aqp8 & -0.2248 \\
\hline & Hsd3b2 & -0.2498 \\
\hline & Prl2c3 & -0.2224 \\
\hline & Isg15 & -0.2855 \\
\hline & Dusp1 & -0.1788 \\
\hline & Ppbp & -0.1658 \\
\hline & Traf1 & -0.2589 \\
\hline & Csf2 & -0.195 \\
\hline & Card14 & -0.2112 \\
\hline & Ifi44 & -0.218 \\
\hline & Lyz2 & -0.1188 \\
\hline & Clu & -0.2 \\
\hline & Prl2c1 & -0.1899 \\
\hline & Tmlhe & -0.4152 \\
\hline & Prl2c5 & -0.1325 \\
\hline & Tgfbi & -0.1859 \\
\hline & Fos & -0.2683 \\
\hline & Hspa1b & -0.2673 \\
\hline Gm13021 & Prl2c3 & -0.1228 \\
\hline Gm19557 & Ppbp & -0.1214 \\
\hline \multirow{3}{*}{ Airn } & $\operatorname{lgf} 2 r$ & -0.2548 \\
\hline & Lyz2 & -0.189 \\
\hline & $\operatorname{lgsf21}$ & -0.1985 \\
\hline
\end{tabular}


Discussão 


\section{Discussão}

Os linfócitos T desempenham um papel fundamental na tolerância central. Em um sistema imunológico funcional, as células $T$ imaturas não reagem contra os auto-antígenos do corpo (KYEWSKI; DERBINSKI, 2004). Ao longo do seu desenvolvimento no timo, passam por etapas essenciais de maturação e reconhecimento de MHC e TRAs próprios, podendo ser eliminados por apoptose ou convertidos em células dendríticas(GOLDRATH; BEVAN, 1999).

Essencial para a maturação das células $T$, o microambiente que compõem o timo, conhecido como estroma tímico, favorece o desenvolvimento de células T e como característica é composto por uma rede de diferentes células como fibroblastos, células mesenquimais não fibroblásticas, células de tecido conjuntivo, endoteliais, células dendríticas, macrófagos, células hematopoiéticas CD45+ e células epiteliais formando a matriz na qual as células progenitoras linfoides T (timócitos) se desenvolvem (GOLDRATH; BEVAN, 1999; TAKABA; TAKAYANAGI, 2017).

Compartimentalizado em duas principais regiões, inicialmente o órgão linfoide timo recebe os timócitos, advindos da medula óssea, em sua região cortical para serem selecionados positivamente por meio de sua capacidade de interação com Moléculas do Complexo principal de Histocompatibilidade (MHC) (REZZANI et al., 2014).

Após o processo de maturação no córtex do timo, onde há a diferenciação dos timócitos em células $\mathrm{T} \mathrm{CD} 4^{+}$ou $\mathrm{CD}^{+}$, o processo migratório dos timócitos segue para a região medular onde ocorrerá a seleção negativa. Para isso, há um crosstalk, células mTEC apresentam as células T um conjunto diversificado de auto antígenos. Uma expressão diversificada de TRAs induzida de forma promíscua pelo gene Aire (SANSOM et al., 2014; ABRAMSON; GOLDFARB, 2016; ANDERSON; SU, 2016).

Neste estudo, usamos a linhagem celular mTEC 3.10 (CD45- ${ }^{-}$EpCam $^{+}$, Lyn51 $1^{-}, \mathrm{UEA1}^{+}$) tipo selvagem, usada em estudos anteriores do nosso laboratório. Além dessas, também utilizamos células mTEC 3.10E6 Aire-/- KO, editadas por meio do uso da ferramenta de edição gênica CRISPR-Cas9. O nocaute dessas células teve como alvo o exon 3 do gene Aire, devido a sua codificação do domínio NLS da proteína AIRE, um domínio envolvido no 
transporte da proteína Aire do citoplasma para o núcleo das células mTEC, e a possibilidade de mutações nessa região interromperem seu comportamento transcricional (SPECK-HERNANDEZ et al., 2018).

A análise da proteína AIRE por Western Blot, utilizando anticorpo primário anti-AIRE, confirmou os resultados prévios do estudo publicado por SpeckHernandez et al. 2018, mostrando que as células mTEC 3.10E6 nocauteadas no exon 3 na região NLS do gene Aire (mTEC 3.10E6 Aire $^{-/}$) apresentaram redução da expressão da proteína AIRE e a proteína expressa é deletéria. Nosso estudo revelou que houve uma redução de $\sim 40 \%$ em relação as células mTEC 3.10 selvagens. Resultado que reafirma que um dos dois alelos mutantes de Aire ${ }^{-/}$ codifica uma proteína truncada, enquanto o outro alelo não apresenta alterações nos domínios SAND e PHD1-2, sendo reconhecidos de igual forma pelo anticorpo (SPECK-HERNANDEZ et al., 2018). Como proteína de referência nessas análises, utilizamos a expressão de GAPDH.

O nocaute do gene Aire, implica em alterações na regulação da expressão de um grande conjunto de genes associados a tolerância central imunológica. Além disso, genes que codificam moléculas de adesão também são perturbados pela redução da expressão de Aire (MACEDO et al., 2015; PEZZI et al., 2016).

Em estudos prévios realizados em nosso laboratório, foi observado que tanto o silenciamento e o nocaute do gene Aire em células mTEC 3.10 resultaram num decréscimo da capacidade destas células aderirem com timócitos (PEZZI et al., 2016; SPECK-HERNANDEZ et al., 2018). Genes envolvidos na adesão célula-célula, como Cd80, Vcam, Icam4, Itgad, Lrrc4b e Lama1 tiveram sua expressão reduzida quando Aire é perturbado.

Considerando que o processo físico de interação entre timócitos e mTECs se faz crucial nos processos de apresentação de antígenos TRAs e amadurecimento das próprias mTECs e células $T$, a ausência de Aire altera toda a estrutura de conexão, comprometendo o funcionamento da tolerância central imunológica (DERBINSKI et al., 2005).

O ponto chave, que orientou o questionamento deste trabalho, envolveu uma das hipóteses de que o crosstalk mTEC-timócito poderia influenciar no perfil de transcritos (RNAs). Por meio do ensaio de adesão, foi possível observar que a cultura de células mTEC 3.10E6 Aire KO com timócitos variando o tempo de co-cultura entre 12 e 36h, houve um decréscimo da adesão quando comparado 
com células mTEC 3.10 WT. Em uma observação visual e ao microscópio optico, não foi encontramos alterações na morfologia celular comparando células mTEC 3.10 WT com células mTEC 3.10E6 Aire KO.

De acordo com a análise de enriquecimento funcional in silico, utilizando a ferramenta DAVID, observamos baixa na expressão de classes de genes envolvidos com o processo biológico de adesão celular e ativação da transcrição do promotor da RNA Pol II, processo que ativa ou aumenta a frequência, taxa ou extensão da transcrição de um promotor de RNA Pol II.

As mTECs expressam em sua superfície milhares de genes que representam antígenos do próprio corpo (autoantígenos ou TRAs) e podem induzir tolerância a uma ampla gama desses TRAs. O gene Aire é essencial no controle da transcrição dos TRAs.

Analisamos o perfil de transcritos em células MTEC 3.10 WT co-cultivadas com timócitos durante 12-36h. Foram modulados um total de 705 mRNAs. As células mTEC 3.10 co-cultivadas com timócitos durante 36h apresentaram 530 mRNAs diferencialmente expressos, um aumento na modulação quando comparado com os 175 mRNAs modulados durante de 12 horas de adesão com timócitos. Foi possível concluir que o tempo de co-cultivo das células mTEC com os timócitos influencia a modulação da expressão de mRNAs. Durante 36 horas de co-cultivo houve um aumento expressivo do número de transcritos em relação a $12 \mathrm{~h}$ de adesão.

Em análise as moléculas de IncRNA em células mTEC 3.10 WT, também foi possível observar a influência da adesão de acordo com o tempo de co-cultivo com timócitos, seguindo o perfil de mRNAs apresentado anteriormente. Foram identificados um total de 107 IncRNAs diferencialmente expressos. A análise das mTECs 3.10 WT co-cultivadas com timócitos durante $12 \mathrm{~h}$ mostrou uma modulação de 34 IncRNAs, enquanto que durante $36 \mathrm{~h}$ houve uma modulação de 73 IncRNAs.

Nas análises das células mTEC 3.10E6 Aire KO co-cultivadas com timócitos, foram identificados um total de 732 mRNAs. A análise das mTEC 3.10 co-cultivadas com timócitos durante 12h mostrou modulação de 263 mRNAs, enquanto que durante $36 \mathrm{~h}$ houve modulação de 469 mRNAs (230 superregulados e 239 sub-regulados). 
Ainda nas células mTEC 3.10E6 Aire KO e analisando os IncRNAs modulados, foram identificados um total de 116 IncRNAs diferencialmente expressos. A análise das mTECs 3.10 co-cultivadas com timócitos durante $12 \mathrm{~h}$ mostrou uma modulação de 43 IncRNAs, enquanto durante $36 \mathrm{~h}$ houve modulação de 73 IncRNAs(19 super-regulados e 54 sub-regulados).

Dentre os IncRNAs já descritos e que exibiram expressão diferencial neste estudo, observamos o Transcrito Abundante Nuclear (NEAT1), que tem como função o controle da formação de estruturas de heterocromatinas, como os Paraspeckles, que são corpos de ribonucleoproteína encontrados no espaço da intercromatina no núcleo e desempenham um papel na regulação da expressão de certos genes em células diferenciadas por meio da retenção de RNA no núcleo (CLEMSON et al., 2009; ZHANG et al., 2013).

Analisando a rede de interação dos mRNAs alvos dos IncRNAS é possível observar que um dos genes Ppbp é alvejado por vários IncRNAs. O gene Ppbp, também conhecido como CXCL7, é um fator de crescimento, poderoso quimioatrativo, ativador de neutrófilos e promove a migração de leucócitos através de trombos plaquetários. No contexto celular do timo, o aumento da expressão do IncRNA NEAT1 pode estar associado a formação de estruturas que retém RNAs para o estimulo e regulação do Ppbp/CXCL7, que por sua vez pode ser um fator essencial de estimulo de migração dos timócitos (KOSIR; YU; BERK, 2010; AGARWALA et al., 2017).

Os genes diferencialmente expressos foram submetidos à análise de enriquecimento funcional com o uso da ferramenta de anotação DAVID, possibilitando a identificação dos processos biológicos envolvidos. O cutoff utilizado foi de $<0.05$ associado com a correção de Benjamini-Hochberg.

A análise dos processos biológicos nas células mTEC 3.10 WT cocultivadas com timócitos não apresentou um perfil diferenciado. Contudo, ao analisar os processos biológicos envolvendo os mRNAs diferencialmente expressos das mTECs 3.10E6 Aire KO, evidenciou-se subregulação de 6 mRNAs associados a adesão durante 12h de adesão mTEC-timócito (NCAM1, ATP1B1, PSTPIP1, ASTN1, CSF3R, ITGB5) e durante de 36h uma subregulação de 12 mRNAs também envolvidos com a adesão (COL4A3, LAMA3, CD44, CTGF, LSAMP, TNC, TCAM1, HAS2, ACKR3, ZYX, FARP2, CYR61). O que chamou nossa atenção foi a desregulação na expressão 
transcricional apenas em células mTEC 3.10E6 Aire KO sugerindo o envolvimento do gene Aire com a expressão de moléculas ligadas a interação célula a célula e matriz celular. mRNAs subregulados e envolvidos com processos de crescimento celular, regulação positiva da expressão gênica e genes de proliferação também foram alterados.

Para o desenvolvimento das células $T$ imaturas é necessário uma interação com a matriz celular do timo composta principalmente de colágeno tipo I e IV, integrinas, laminina e fibronectina (SAVINO et al., 2004).

Genes que codificam as integrinas estão envolvidas na interação com a matriz extracelular, contato físico célula-célula e atuam como receptores de adesão. São essenciais nos processos que modulam a proliferação e diferenciação de células T (SAVINO et al., 2003, 2004, 2015; BERTONI et al., 2018).

Como uma das características funcionais dos IncRNAs, o seu sitio de atuação pode variar em cis, quando atuam regulando o próprio local onde foram transcritos ou em trans indo para outras regiões do genoma para exercerem sua função. Diante dessa informação mapeamos a localização cromossômica de cada IncRNA diferencialmente expresso, o que possibilitou a identificação dos genes codificares de proteínas upstream e downstream dos IncRNAs.

A conexão entre essas duas informações possibilitou encontrar IncRNAs que possivelmente poderiam ter como alvo algum mRNAs cuja localização de seus genes estariam upstream ou downstream e ao mesmo tempo diferencialmente expresso nas duas condições deste estudo (células mTEC Aire WT e células mTEC Aire KO).

Foi possível destacar o IncRNA Tnk2os e gene Tnk2 localizado upstream. Esse IncRNA e o mRNA Tnk2 possuem uma interação forte de -0.1937 ndG (cutoff -0.1). O algoritmo do LncTar utlizado determina que para considerar que há interação entre duas moléculas de RNA, a energia de interação livre normalizada (ndG) calculada deverá ser igual ou menor que o valor do cutoff utilizado.

O gene Tnk2 está envolvido na regulação da função das células dendríticas nos gânglios linfáticos e na vigilância de processos tumorais no timo. Um estudo mostrou que mutações no gene Tnk2 induzem ao quadro de epilepsia infantil, podendo ser imunoneurológica (HITOMI et al., 2013). Já o IncRNA 
Tnk2os é muito expresso no timo, porém ainda não anotações sobre sua função e atuação.

Este trabalho procurou trazer uma inovação científica ao estudo do controle transcricional e pós-transcricional das células mTEC. A base que orientou a formulação das hipóteses está no mecanismo de atuação da proteína Aire, a qual libera a RNA Pol II ancorada na cromatina (Giraud et al 2012). Como a RNA Pol II além de transcrever moléculas de mRNA, também transcreve moléculas de miRNA (Macedo et al 2013). Como os IncRNAs também são transcritos pela RNA Pol II nos pareceu lógico considerar que Aire pudesse regular essa espécie de RNA em células mTEC.

Esse achado é original e inédito na pesquisa sobre as células mTEC e representa, portanto, uma contribuição importante. 
Conclusões 


\section{Conclusões}

- Este estudo mostrou que as células mTEC 3.10E6 Aire KO apresentaram in vitro redução em sua capacidade de adesão com os timócitos (crosstalk). Isso evidenciou o envolvimento do gene Aire na regulação de genes ligados ao processo de adesão célula-célula.

- Foi possível evidenciar o papel de Aire na regulação de IncRNAs em células mTEC, confirmando uma das hipóteses adotadas nesse trabalho (Figura 8).

- Foi possível evidenciar que o crosstalk, entre mTEC 3.10 Aire WT com timócitos, induziu aumento no número de mRNAs e de IncRNAs diferencialmente expressos segundo o tempo de co-cultura, confirmando uma das hipóteses adotadas nesse trabalho. A grande maioria dos IncRNAs diferencialmente expressos e regulados por Aire são da classe dos intergênicos.

- Existe a possibilidade predita de interação entre os IncRNAs e mRNAs diferencialmente expressos, sinalizando a existência de um novo mecanismo de controle da expressão gênica pós-transcricional em células tímicas epiteliais medulares (mTECs). 
$\underline{\text { Referências Bibliográficas }}$ 


\section{Referências Bibliográficas}

ABBOTT, J. K. et al. Dominant-negative loss of function arises from a second, more frequent variant within the SAND domain of autoimmune regulator (AIRE). Journal of Autoimmunity, v. 88, p. 114-120, 2018.

ABRAMSON, J. et al. Aire's Partners in the Molecular Control of Immunological Tolerance. Cell, v. 140, n. 1, p. 123-135, 2010.

ABRAMSON, J.; GOLDFARB, Y. AIRE: From promiscuous molecular partnerships to promiscuous gene expression. European Journal of Immunology, v. 46, n. 1, p. 22-33, jan. 2016. Disponível em: <http://doi.wiley.com/10.1002/eji.201545792>. Acesso em: 23 jan. 2017.

AGARWALA, R. et al. Database Resources of the National Center for Biotechnology Information, Nucleic Acids Research, v. 45, n. Database issue, p. D12, 2017.

ANDERSON, G.; TAKAHAMA, Y. Thymic epithelial cells: Working class heroes for $T$ cell development and repertoire selection. Trends in Immunology, v. 33, n. 6, p. 256-263, 2012.

ANDERSON, M. S.; SU, M. A. AIRE expands: New roles in immune tolerance and beyond. Nature Reviews Immunology, v. 16, n. 4, p. 247, 2016.

BENJAMINI, Y.; HOCHBERG, Y. Controlling the false discovery rate: a practical and powerful approach to multiple testing. Journal of the Royal Statistical Society. Series B (Methodological), p. 289-300, 1995.

BERTONI, A. et al. Integrins in T cell physiology. International Journal of Molecular Sciences, v. 19, n. 2, p. 485, 2018.

BLECHSCHMIDT, $K$. et al. The mouse Aire gene: comparative genomic sequencing, gene organization, and expression. Genome research, v. 9, n. 2, p. 158-166, 1999.

BRENNECKE, P. et al. Single-cell transcriptome analysis reveals coordinated ectopic gene-expression patterns in medullary thymic epithelial cells. Nature Immunology, v. 16, n. 9, p. 933, 2015.

BRUSERUD, $\varnothing$. et al. AIRE-mutations and autoimmune disease. Current Opinion in Immunology, v. 43, p. 8-15, 2016.

CARPENTER, S. et al. A long noncoding RNA mediates both activation and repression of immune response genes. Science (New York, NY), v. 341, n. 6147, p. 789-792, 2013.

CHINN, I. K. et al. Changes in primary lymphoid organs with aging. Seminars in Immunology, Vol. 24, No. 5, pp. 309-320, 2012.

CHOI, S.-W.; KIM, H.-W.; NAM, J.-W. The small peptide world in long noncoding 
RNAs. Briefings in Bioinformatics, v. 23, n. 13, p. 1494-1504, 2018.

CLEMSON, C. M. et al. An Architectural Role for a Nuclear Noncoding RNA: NEAT1 RNA Is Essential for the Structure of Paraspeckles. Molecular Cell, v. 33, n. 6, p. 717-726, 2009.

DERBINSKI, J. et al. Promiscuous gene expression in medullary thymic epithelial cells mirrors the peripheral self. Nature Immunology, v. 2, p. 1032, 15 out. 2001.

DERBINSKI, J. et al. Promiscuous gene expression in thymic epithelial cells is regulated at multiple levels. The Journal of Experimental Medicine, v. 202, n. 1, p. 33-45, 2005.

DERBINSKI, J. et al. Promiscuous gene expression patterns in single medullary thymic epithelial cells argue for a stochastic mechanism. Proceedings of the National Academy of Sciences, v. 105, n. 2, p. 657-662, 2008.

DERBINSKI, J. et al. Promiscuous gene expression in medullary thymic epithelial cells mirrors the peripheral self. Journal of Immunology, v. 196, n. 7, p. 29152922, 2016.

FAN, Y. et al. Thymus-specific deletion of insulin induces autoimmune diabetes. EMBO Journal, v. 28, n. 18, p. 2812-2824, 2009.

FÖRSTER, R.; DAVALOS-MISSLITZ, A. C.; ROT, A. CCR7 and its ligands: Balancing immunity and tolerance. Nature Reviews Immunology, v. 28, n. 18, p. $2812-2824,2008$. .

GALLÓN, S.; LOUBES, J. M.; MAZA, E. Statistical properties of the quantile normalization method for density curve alignment. Mathematical Biosciences, v. 242, n. 2, p. 129-142, 2013.

GIRAUD, M. et al. Aire unleashes stalled RNA polymerase to induce ectopic gene expression in thymic epithelial cells. Proceedings of the National Academy of Sciences, v. 109, n. 2, p. 535-540, 2012.

GOLDMAN, K. P. et al. Thymic cortical epithelium induces self tolerance. European Journal of Immunology, v. 35, n. 3, p. 709-717, 2005.

GOLDRATH, A. W.; BEVAN, M. J. Selecting and maintaining a diverse T-cell repertoire. Nature, v. 402, n. 6759 , p. 255, 1999.

GOTTER, J. et al. Medullary Epithelial Cells of the Human Thymus Express a Highly Diverse Selection of Tissue-specific Genes Colocalized in Chromosomal Clusters. The Journal of Experimental Medicine, v. 199, n. 2, p. 155-166, 2004.

GUI, J. et al. Thymus Size and Age-related Thymic Involution: Early Programming, Sexual Dimorphism, Progenitors and Stroma. Aging and disease, v. 3, n. 3, p. 280, 2012.

HEBERLE, $\mathrm{H}$. et al. InteractiVenn: A web-based tool for the analysis of sets 
through Venn diagrams. BMC Bioinformatics, v. 16, n. 1, p. 169, 2015.

HITOMI, Y. et al. Mutations in TNK2 in severe autosomal recessive infantile onset epilepsy. Annals of Neurology, v. 74, n. 3, p. 496-501, 2013.

HOGQUIST, K. A.; BALDWIN, T. A.; JAMESON, S. C. Central tolerance: Learning self-control in the thymus. Nature Reviews Immunology, v. 5, n. 10, p. 772,2005 . .

$\mathrm{HU}$, G. et al. Expression and regulation of intergenic long noncoding RNAs during T cell development and differentiation. Nature Immunology, v. 14, n. 11, p. 1190 2013.

HUANG, W. et al. DDX5 and its associated IncRNA Rmrp modulate TH17 cell effector functions. Nature, v. 528, n. 7583, p. 517, 2015.

IMAMURA, K. et al. Long Noncoding RNA NEAT1-Dependent SFPQ Relocation from Promoter Region to Paraspeckle Mediates IL8 Expression upon Immune Stimuli. Molecular Cell, v. 53, n. 3, p. 393-406, 2014.

KANG, Y. J. et al. CPC2: A fast and accurate coding potential calculator based on sequence intrinsic features. Nucleic Acids Research, v. 45, n. W1, p. W12W16 2017.

KLEIN, L. et al. Positive and negative selection of the T cell repertoire: What thymocytes see (and don't see). Nature Reviews Immunology, v. 14, n. 6, p. 377, 2014.

KLEIN, L. Aire Gets Company for Immune Tolerance. Cell, v. 163, n. 4, p. 794795, 2015.

KONG, L. et al. CPC: Assess the protein-coding potential of transcripts using sequence features and support vector machine. Nucleic Acids Research, v. 35, n. suppl_2, p. W345-W349, 2007.

KOO, G. C.; PEPPARD, J. R.; HATZFELD, a. Ontogeny of Nk-1+ natural killer cells. I. Promotion of Nk-1+ cells in fetal, baby, and old mice. Journal of immunology (Baltimore, Md. : 1950), v. 129, n. 2, p. 867-871, 1982.

KOSIR, M. A.; YU, M.; BERK, R. CXCL7-mediated stimulation of lymphangiogenic factors VEGF-C, VEGF-D in human breast cancer cells. Journal of Oncology, v. 2010, 2010.

KUNG, J. T. Y.; COLOGNORI, D.; LEE, J. T. Long noncoding RNAs: Past, present, and future. Genetics, v. 193, n. 3, p. 651-669, 2013.

KUROBE, $\mathrm{H}$. et al. CCR7-dependent cortex-to-medulla migration of positively selected thymocytes is essential for establishing central tolerance. Immunity, v. 24, n. 2, p. 165-177, 2006.

KYEWSKI, B.; DERBINSKI, J. Self-representation in the thymus: An extended view. Nature Reviews Immunology, v. 4, n. 9, p. 688, 2004. . 
LAU, C. I. et al. Foxa1 and Foxa2 in thymic epithelial cells (TEC) regulate medullary TEC and regulatory T-cell maturation. Journal of Autoimmunity, v. 93, p. 131-138, 2018.

LI, J. et al. LncTar: A tool for predicting the RNA targets of long noncoding RNAs. Briefings in Bioinformatics, v. 16, n. 5, p. 806-812, 2014.

LIANG, J. C.; BLOOM, R. J.; SMOLKE, C. D. Engineering Biological Systems with Synthetic RNA Molecules Molecular. Cell, v. 43, n. 6, p. 915-926, 2011.

MACEDO, C. et al. Autoimmune regulator (Aire) controls the expression of microRNAs in medullary thymic epithelial cells. Immunobiology, v. 218, n. 4, p. 554-560, 2013.

MACEDO, C. et al. Aire-dependent peripheral tissue antigen mRNAs in mTEC cells feature networking refractoriness to microRNA interaction. Immunobiology, v. 220, n. 1, p. 93-102, 2015.

MATHIS, D.; BENOIST, C. A decade of AIRE. Nature Reviews Immunology, v. 7, n. 8, p. 645, 2007.

MENDES-DA-CRUZ, D. A. et al. Developing T-cell migration: Role of semaphorins and ephrins. FASEB Journal, v. 26, n. 11, p. 4390-4399, 2012.

MERCER, T. R.; MATTICK, J. S. Structure and function of long noncoding RNAs in epigenetic regulation. Nature Structural \&amp; Molecular Biology, 2013.

MEREDITH, M. et al. Aire controls gene expression in the thymic epithelium with ordered stochasticity. Nature Immunology, v. 16, n. 9, p. 942-949, 2015.

MILLER, J. F. A. P. The discovery of thymus function and of thymus-derived lymphocytes. Immunological Reviews, v. 185, n. 1, p. 7-14, 2002.

NISHIJIMA, H. et al. Paradoxical development of polymyositis-like autoimmunity through augmented expression of autoimmune regulator (AIRE). Journal of Autoimmunity, v. 86, p. 75-92, 2018.

OLIVEIRA, E. H. et al. Aire Downregulation Is Associated with Changes in the Posttranscriptional Control of Peripheral Tissue Antigens in Medullary Thymic Epithelial Cells. Frontiers in Immunology, v. 7, p. 526, 23 nov. 2016.

PALMA, A. et al. Analysis of the autoimmune regulator gene in patients with autoimmune non-APECED polyendocrinopathies. Genomics, v. 102, n. 3, p. 163-168, 2013.

PASSOS, G. A. et al. Update on Aire and thymic negative selection. Immunology, v. 153, n. 1, p. 10-20, 2018.

PAYRE, F.; DESPLAN, C. RNA. Small peptides control heart activity. Science (New York, N.Y.), v. 351, n. 6270, p. 226-227,2016.

PEZZI, N. et al. Aire knockdown in medullary thymic epithelial cells affects Aire 
protein, deregulates cell adhesion genes and decreases thymocyte interaction. Molecular Immunology, v. 77, p. 157-173, set. 2016.

PINTO, S. et al. Overlapping gene coexpression patterns in human medullary thymic epithelial cells generate self-antigen diversity. Proceedings of the National Academy of Sciences, v. 110, n. 37, p. E3497-E3505, 2013.

PONTING, C. P.; OLIVER, P. L.; REIK, W. Evolution and Functions of Long Noncoding RNAs. Cell, v. 136, n. 4, p. 629-641, 2009.

REZZANI, R. et al. Thymus and aging: Morphological, radiological, and functional overview. Age, v. 36, n. 1, p. 313-351, 2014. .

RINN, J. L.; CHANG, H. Y. Genome Regulation by Long Noncoding RNAs. Annual Review of Biochemistry, v. 81, p. 145-166, 2012.

RITCHIE, M. E. et al. A comparison of background correction methods for twocolour microarrays. Bioinformatics, v. 23, n. 20, p. 2700-2707, 2007.

RITCHIE, M. E. et al. Limma powers differential expression analyses for RNAsequencing and microarray studies. Nucleic Acids Research, v. 43, n. 7, p. e47e47, 2015.

ROSSI, S. W. et al. RANK signals from CD4 $+3-$ inducer cells regulate development of Aire-expressing epithelial cells in the thymic medulla. The Journal of Experimental Medicine, v. 204, n. 6, p. 1267-1272, 2007.

SANSOM, S. N. et al. Population and single-cell genomics reveal the Aire dependency, relief from Polycomb silencing, and distribution of self-antigen expression in thymic epithelia. Genome Research, v. 24, n. 12, p. 1918-1931, 2014.

SAVINO, W. et al. Thymocyte migration: An affair of multiple cellular interactions? Brazilian Journal of Medical and Biological Research, v. 36, n. 8, p. 10151025, 2003.

SAVINO, W. et al. Molecular mechanisms governing thymocyte migration: combined role of chemokines and extracellular matrix. Journal of Leukocyte Biology, v. 75, n. 6, p. 951-961, 2004.

SAVINO, W. et al. Laminin-mediated interactions in thymocyte migration and development. Frontiers in Immunology, v. 6, p. 579, 2015.

SHANNON, P. et al. Cytoscape: A software Environment for integrated models of biomolecular interaction networks. Genome Research, v. 13, n. 11, p. 24982504, 2003.

SPECK-HERNANDEZ, C. A. et al. Aire disruption influences the medullary thymic epithelial cell transcriptome and interaction with thymocytes. Frontiers in Immunology, v. 9, 2018.

STARR, T. K.; JAMESON, S. C.; HOGQUIST, K. A. Positive and negative 
selection of T cells. Annual review of immunology, v. 21, n. 1, p. 139-176, 2003.

ANDERSON, M. S. et al. Aire expands: new roles in immune tolerance and beyond. Nature Reviews Immunology. v. 16, n. 4, p. 247-258, 2017.

TAKABA, $\mathrm{H}$. et al. Fezf2 Orchestrates a Thymic Program of Self-Antigen Expression for Immune Tolerance. Cell, v. 163, n. 4, p. 975-987, 2015.

TAKABA, H.; TAKAYANAGI, H. The Mechanisms of T Cell Selection in the Thymus.Trends in Immunology, v. 38, n. 11, p. 805-816, 2017.

TAUB, D. D.; LONGO, D. L. Insights into thymic aging and regeneration. Immunological Reviews, v. 205, n. 1, p. 72-93, 2005.

ULYANCHENKO, S. et al. Identification of a Bipotent Epithelial Progenitor Population in the Adult Thymus. Cell Reports, v. 14, n. 12, p. 2819-2832, 2016.

WALLAERT, A. et al. T-ALL and thymocytes: A message of noncoding RNAs. Journal of Hematology and Oncology, v. 10, n. 1, p. 66, 2017.

WANG, Y. et al. Long noncoding RNA derived from CD244 signaling epigenetically controls CD8 + T-cell immune responses in tuberculosis infection. Proceedings of the National Academy of Sciences, v. 112, n. 29, p. E3883E3892, 2015.

WATERFIELD, M. et al. The transcriptional regulator Aire coopts the repressive ATF7ip-MBD1 complex for the induction of immunotolerance. Nature Immunology, v. 15, n. 3, p. 258, 2014.

ZHANG, Q. et al. NEAT1 long noncoding RNA and paraspeckle bodies modulate HIV-1 posttranscriptional expression. mBio, v. 4, n. 1, p. e00596-12, 2013.

ZHANG, Y.; TAO, Y.; LIAO, Q. Long noncoding RNA: a crosslink in biological regulatory network. Briefings in Bioinformatics, 2017.

ZHENG, D. et al. Pseudogenes in the ENCODE regions: Consensus annotation, analysis of transcription, and evolution. Genome Research, v. 17, n. 6, p. 839851, 2007. 
Apêndice 


\title{
12. Apêndice
}

\begin{abstract}
Apêndice 1 Posicionamento cromossômico dos IncRNAs diferencialmente expressos. Posição cromossômica onde cada IncRNA se encontra no genoma GRCm38.p6
\end{abstract}

\begin{tabular}{|c|c|}
\hline LncRNA & $\begin{array}{l}\text { Localização } \\
\text { cromossômica }\end{array}$ \\
\hline 1700030M09Rik & 8qE1 \\
\hline 1700080N15Rik & $2 q A 1$ \\
\hline 2610016A17Rik & $19 q C$ \\
\hline 3010001F23Rik-201 & $X q$ \\
\hline 4632427E13Rik & $7 q E 1$ \\
\hline 4930557B15Rik & XqA2 \\
\hline 4933405E24Rik-201 & $11 q B 1.3$ \\
\hline 4933438K21Rik-201 & $4 q E 1$ \\
\hline 5430431A17Rik-201 & $7 q B 3$ \\
\hline 9430078K24Rik & $12 q C 3$ \\
\hline 9530014B07Rik & 13qB1 \\
\hline A130077B15Rik & 10qD2 \\
\hline AC159290.2-201 & $13 q B 3$ \\
\hline Airn & 17qA1 \\
\hline chr1:183951156-183986156_F & $1 q$ \\
\hline chr1:69531191-69570566_R & $1 q$ \\
\hline chr10:96098058-96098623_F & $10 q$ \\
\hline $\begin{array}{l}\text { chr11:119254413- } \\
\text { 119296960_F }\end{array}$ & $11 q$ \\
\hline chr11:18479852-18485704_F & $11 q$ \\
\hline chr11:50994911-51050704_F & $11 q$ \\
\hline chr11:60728207-60745369_R & $11 q$ \\
\hline $\begin{array}{l}\text { chr13:113205145- } \\
\text { 113207570_F }\end{array}$ & $13 q$ \\
\hline chr16:23992037-24001037_F & $16 q$ \\
\hline chr18:63355660-63369610_R & $18 q$ \\
\hline chr18:63525907-63526504_R & $18 q$ \\
\hline chr19:5771425-5848475_F & $19 q$ \\
\hline chr2:128211990-128215223_R & $2 q$ \\
\hline chr2:151992806-152025456_R & $2 q$ \\
\hline chr2:172343878-172344212_R & $2 q$ \\
\hline chr2:176610409-176612864_F & $2 q$ \\
\hline chr3:113296823-113298691_R & $3 q$ \\
\hline chr3:85783094-85783408_F & $3 q$ \\
\hline chr4:135138014-135174889_F & $4 q$ \\
\hline chr4:33375464-33377138_R & $4 q$ \\
\hline
\end{tabular}




\begin{tabular}{|c|c|}
\hline chr4:98943050-98959998_R & $4 q$ \\
\hline chr5:113594167-113645342_R & $5 q$ \\
\hline chr5:14943275-14944205_F & $5 q$ \\
\hline chr5:15146475-15170100_F & $5 q$ \\
\hline chr6:121035524-121061074_R & $6 q$ \\
\hline chr6:31078802-31079644_R & $6 q$ \\
\hline chr6:83368261-83407280_R & $6 q$ \\
\hline chr8:124355710-124401160_R & $8 q$ \\
\hline chr8:126396600-126407275_R & $8 q$ \\
\hline chr8:85952719-85958369_R & $8 q$ \\
\hline chrX:11693432-11693908_R & $\mathrm{Xq}$ \\
\hline chrX:91000651-91005855_R & $\mathrm{Xq}$ \\
\hline D930048N14Rik & $11 q B 1.3$ \\
\hline Foxo3-202 & 10qB2 \\
\hline Gm10416 & $5 q F$ \\
\hline Gm10536 & 18qD3 \\
\hline Gm11033-203 & $8 q C 1$ \\
\hline Gm14230 & $2 \mathrm{qH} 1$ \\
\hline Gm15614 & $5 q B 1$ \\
\hline Gm15738 & 16qA1 \\
\hline Gm17821 & $12 q C 2$ \\
\hline Gm19327 & $12 q D 1$ \\
\hline Gm19557 & $19 q D 1$ \\
\hline Gm19639 & $19 q C 3$ \\
\hline Gm34589 & $14 q E 2.3$ \\
\hline Gm35147 & $7 q F 3$ \\
\hline Gm35358 & $8 q C 3$ \\
\hline Gm36582 & $6 q G 1$ \\
\hline Gm4262 & $16 q A 1$ \\
\hline Gm4316 & 8qE1 \\
\hline Gm43391 & $5 q A 3$ \\
\hline Gm4425 & $12 q A 1.3$ \\
\hline Gm4610-201 & $3 q G 1$ \\
\hline Gm6507-201 & $6 q D 1$ \\
\hline LOC105243194 & $8 q B 2$ \\
\hline Map2k3os-201 & $11 q B 2$ \\
\hline Mir22hg & $11 q B 5$ \\
\hline Mirg-205 & $12 q F 1$ \\
\hline Neat1-201 & $19 q A$ \\
\hline Platr28-201 & $7 q E 3$ \\
\hline Slc2a4rg-ps & $2 \mathrm{qH} 4$ \\
\hline Snhg7os-202 & $2 q A 3$ \\
\hline Tnk2os-201 & $16 q B 3$ \\
\hline XIST & $X q D$ \\
\hline Xist-202 & $X q D$ \\
\hline
\end{tabular}




\begin{tabular}{|c|c|}
\hline 1700047G07Rik-201 & 8qD1 \\
\hline 2500002B13Rik & $8 q B 2$ \\
\hline 2810402E24Rik-201 & $14 q A 3$ \\
\hline 3010003L21Rik & $6 q G 3$ \\
\hline 4930447F24Rik & $9 q F 1$ \\
\hline 4930542C21Rik & $16 q B 3$ \\
\hline 4932431P20Rik-202 & $7 q B 1$ \\
\hline 4933429K18Rik & $19 C 3$ \\
\hline 5031425E22Rik-205 & $5 q A 3$ \\
\hline 5430416N02Rik-202 & $5 q E 5$ \\
\hline 6720427I07Rik & $13 q A 5$ \\
\hline 9230102O04Rik-201 & $2 q A 1$ \\
\hline AC160966.2-201 & 9qA5.1 \\
\hline B130024G19Rik-202 & $7 q C$ \\
\hline C78283-201 & $5 q C 3.3$ \\
\hline Cdk3-ps & $11 q E 2$ \\
\hline chr1:74084292-74138492_F & $1 q$ \\
\hline chr10:93975406-93977476_R & $10 q$ \\
\hline chr10:96103732-96103867_F & $10 q$ \\
\hline $\begin{array}{l}\text { chr12:112220578- } \\
\text { 112220962_F }\end{array}$ & $12 q$ \\
\hline chr12:73789535-73799787_F & $12 q$ \\
\hline chr12:88172043-88172731_R & $12 q$ \\
\hline chr14:21621875-21638625_R & $14 q$ \\
\hline chr14:78957377-78962977_R & $14 q$ \\
\hline chr14:99729955-99730583_F & $14 q$ \\
\hline chr15:5446560-5549135_R & $15 q$ \\
\hline chr15:79764481-79809909_F & $15 q$ \\
\hline chr15:83281223-83284791_R & $15 q$ \\
\hline chr15:85502461-85524051_R & $15 q$ \\
\hline chr15:98842850-98853100_F & $15 q$ \\
\hline chr17:3198868-3394643_F & $17 q$ \\
\hline chr17:84477999-84489215_F & $17 q$ \\
\hline chr18:75513062-75523889_R & $18 q$ \\
\hline chr19:4209657-4210475_R & $19 q$ \\
\hline chr19:5001448-5001810_R & $19 q$ \\
\hline chr19:57426515-57435165_R & $19 q$ \\
\hline chr2:116796887-116797441_F & $2 q$ \\
\hline chr2:143988645-143993945_F & $2 q$ \\
\hline chr2:156654675-156665430_F & $2 q$ \\
\hline chr2:25774411-25783757_F & $2 q$ \\
\hline chr3:151746091-151753763_F & $3 q$ \\
\hline chr3:34793853-34800591_F & $3 q$ \\
\hline chr3:65729664-65731697_R & $3 q$ \\
\hline chr3:90425270-90435820_F & $3 q$ \\
\hline
\end{tabular}




\begin{tabular}{|c|c|}
\hline chr3:96074625-96086375_R & $3 q$ \\
\hline chr4:141527564-141547339_F & $4 q$ \\
\hline chr4:146017200-146029700_F & $4 q$ \\
\hline chr4:3009566-3009932_R & $4 q$ \\
\hline chr5:74487385-74497428_R & $5 q$ \\
\hline chr6:108556270-108573161_F & $6 q$ \\
\hline chr6:140639450-140662200_R & $6 q$ \\
\hline chr6:31007184-31007725_R & $6 q$ \\
\hline chr6:47700758-47717846_F & $6 q$ \\
\hline chr7:129293609-129294172_R & $7 q$ \\
\hline chr7:134649844-134651551_F & $7 q$ \\
\hline chr7:31709550-31723025_F & $7 q$ \\
\hline chr8:110197171-110206546_R & $8 q$ \\
\hline chr8:124397412-124398022_R & $8 q$ \\
\hline chr8:124569775-124639500_F & $8 q$ \\
\hline chr8:126268510-126290810_R & $8 q$ \\
\hline chr8:18587198-18592948_R & $8 q$ \\
\hline chr8:20014569-20016673_R & $8 q$ \\
\hline chr8:26212577-26218527_F & $8 q$ \\
\hline chr8:35650475-35664200_F & $8 q$ \\
\hline chr8:48476637-48492537_F & $8 q$ \\
\hline chr8:87504644-87513694_R & $8 q$ \\
\hline chr9:31839533-31840971_R & $9 q$ \\
\hline chr9:68349343-68411643_F & $9 q$ \\
\hline chrX:123306246-123307974_F & $\mathrm{Xq}$ \\
\hline chrX:20570399-20571162_F & $\mathrm{Xq}$ \\
\hline chrX:75813213-75829323_F & $\mathrm{Xq}$ \\
\hline СТ033783.2-201 & $13 q B 3$ \\
\hline Fam219aos-201 & $4 q A 5$ \\
\hline Gm11423-202 & $11 q C$ \\
\hline Gm12440 & $3 q F .2$ \\
\hline Gm12576-201 & $11 q C$ \\
\hline Gm13021-201 & $4 q D 3$ \\
\hline Gm14230-201 & $2 q \mathrm{H} 1$ \\
\hline Gm14636-201 & $\mathrm{XqA} 2$ \\
\hline Gm15850 & $1 q E 4$ \\
\hline Gm16124 & $9 q A 5.3$ \\
\hline Gm16159 & $8 q A 2$ \\
\hline Gm19589 & $1 q D$ \\
\hline Gm26853-201 & 8qA1.3 \\
\hline Gm28331-201 & YqA1 \\
\hline Gm32575 & $19 q D 2$ \\
\hline Gm33302 & 9qE3.3 \\
\hline Gm35677 & $8 q E 1$ \\
\hline Gm37640-201 & $3 q A 3$ \\
\hline
\end{tabular}




\begin{tabular}{lc}
\hline Gm43058-201 & $5 q A 3$ \\
\hline$G m 43391-201$ & $5 q A 1$ \\
\hline$G m 4827$ & $16 q B 5$ \\
\hline$G m 567-201$ & $3 q G 3$ \\
\hline Gm5914 & $8 q D 3$ \\
\hline LOC73899 & $19 q D 2$ \\
\hline Lockd-201 & $6 q G 1$ \\
\hline Mirt1-202 & $19 q D 2$ \\
\hline SEAT1 & $19 q A$ \\
\hline Snora74a & $18 q B 2$ \\
\hline Zbtb38-206 & $1 q \mathrm{H} 1$ \\
\hline
\end{tabular}

Apêndice 2 LncRNAs e seu potencial codificador. Potencial codificador de cada IncRNA calculado pela ferramenta Coding Potential Calculator 2CPC2. (PC- Potencial Codificador).

\section{LncRNA}

chr1:135830093-135840837_F

chr1:135956616-135957485_R

chr1:162965309-162970704_F

chr1:183811267-183816309_F

chr1:183951156-183986156_F

chr1:69531191-69570566_R

chr1:74084292-74138492_F

chr10:116814196-116920696_R

chr10:121498271-121512171_R

chr10:8606683-8665783_R

chr10:93975406-93977476_R

chr10:96098058-96098623_F

chr10:96103732-96103867_F

chr11:119254413-119296960_F

chr11:18479852-18485704_F

chr11:50994911-51050704_F

chr11:53574182-53574644_R

chr11:60728207-60745369_R

chr11:6421951-6429173_R

chr11:70196232-70203307_R

chr11:82588507-82594501_R

chr12:112220578-112220962_F
Coding Potential Calculator 2

(CPC2)

$\begin{array}{cc}\text { Score } & \text { PC } \\ 0.0154964 & \text { NC } \\ 0.00676454 & \text { NC } \\ 0.00516844 & \text { NC } \\ 0.0597192 & \text { NC } \\ 0.0188792 & \text { NC } \\ 0.00856357 & \text { NC } \\ 0.0143317 & \text { NC } \\ 0.00285516 & \text { NC } \\ 0.200652 & \text { NC } \\ 1.60076 \mathrm{e}-05 & \text { NC } \\ 0.00263757 & \text { NC } \\ 0.00346511 & \text { NC } \\ 0.0141289 & \text { NC } \\ 1.31358 \mathrm{e}-06 & \text { NC } \\ 0.0347571 & \text { NC } \\ 1.26344 \mathrm{e}-05 & \text { NC } \\ 0.0536091 & \text { NC } \\ 0.0308508 & \text { NC } \\ 0.0395833 & \text { NC } \\ 0.155216 & \text { NC } \\ 0.186986 & \text { NC } \\ 0.0047507 & \text { NC }\end{array}$




\begin{tabular}{|c|c|c|}
\hline chr12:16003706-16022581_F & 0.0126949 & NC \\
\hline chr12:21548850-21568550_R & 0.0503324 & NC \\
\hline chr12:73789535-73799787_F & $3.11582 \mathrm{e}-06$ & NC \\
\hline chr12:76744947-76778372_R & $1.66007 \mathrm{e}-05$ & NC \\
\hline chr12:88172043-88172731_R & 0.0258632 & NC \\
\hline chr13:113205145-113207570_F & $6.80076 \mathrm{e}-06$ & NC \\
\hline chr13:41337973-41379821_F & 0.00838164 & NC \\
\hline chr13:62734450-62785325_R & $2.19521 \mathrm{e}-06$ & NC \\
\hline chr13:73472571-73483846_F & $1.09402 \mathrm{e}-06$ & NC \\
\hline chr14:115443612-115445950_F & $1.69872 \mathrm{e}-05$ & NC \\
\hline chr14:21461716-21462270_F & 0.00895532 & NC \\
\hline chr14:21621875-21638625_R & 0.0324885 & NC \\
\hline chr14:62263564-62307496_R & $5.96505 e-06$ & NC \\
\hline chr14:78957377-78962977_R & 0.192874 & NC \\
\hline chr14:99729955-99730583_F & 0.11962 & NC \\
\hline chr15:41288197-41522572_R & $1.35175 e-05$ & NC \\
\hline chr15:5446560-5549135_R & 0.0114658 & NC \\
\hline chr15:79764481-79809909_F & 0.0453376 & NC \\
\hline chr15:83281223-83284791_R & 0.0110769 & NC \\
\hline chr15:84737071-84753513_F & 0.0110163 & NC \\
\hline chr15:85502461-85524051_R & 0.00962752 & NC \\
\hline chr15:98842850-98853100_F & 0.00480843 & NC \\
\hline chr16:23992037-24001037_F & $5.64316 \mathrm{e}-07$ & NC \\
\hline chr16:32388843-32395264_R & 0.00907785 & NC \\
\hline chr16:4585697-4594022_R & 0.00706251 & NC \\
\hline chr17:3198868-3394643_F & 0.00957166 & NC \\
\hline chr17:32213027-32228368_R & 0.0657028 & NC \\
\hline chr17:46972160-46997919_R & 0.0098946 & NC \\
\hline chr17:47016870-47017498_F & 0.0400672 & NC \\
\hline chr17:56687541-56694616_R & 0.0255612 & NC \\
\hline chr17:84477999-84489215_F & 0.030205 & NC \\
\hline chr18:36481237-36481819_F & 0.00872039 & NC \\
\hline chr18:63355660-63369610_R & 0.00698245 & NC \\
\hline chr18:63525907-63526504_R & $4.2705 \mathrm{e}-06$ & NC \\
\hline chr18:69923410-69965360_F & $3.9075 e-06$ & NC \\
\hline chr18:75513062-75523889_R & 0.090413 & NC \\
\hline chr18:90750100-90772025_F & $1.68037 \mathrm{e}-06$ & NC \\
\hline chr19:4209657-4210475_R & 0.103387 & NC \\
\hline chr19:57426515-57435165_R & 0.0106604 & NC \\
\hline chr19:5771425-5848475_F & 0.0172192 & NC \\
\hline chr19:5834117-5835940_R & 0.00943656 & NC \\
\hline
\end{tabular}




\begin{tabular}{|c|c|c|}
\hline chr2:116796887-116797441_F & 0.0113075 & NC \\
\hline chr2:128211990-128215223_R & 0.00524351 & NC \\
\hline chr2:143988645-143993945_F & 0.014967 & NC \\
\hline chr2:151992806-152025456_R & $1.45029 \mathrm{e}-05$ & NC \\
\hline chr2:156654675-156665430_F & 0.0123822 & NC \\
\hline chr2:156654675-156665430_R & $6.35676 \mathrm{e}-07$ & NC \\
\hline chr2:172343878-172344212_R & 0.0104291 & NC \\
\hline chr2:173421598-173485043_R & 0.00293408 & NC \\
\hline chr2:176610409-176612864_F & $1.3969 \mathrm{e}-05$ & NC \\
\hline chr2:22782700-22801900_F & 0.00441765 & NC \\
\hline chr2:25774411-25783757_F & 0.0194916 & NC \\
\hline chr3:113296823-113298691_R & 0.103809 & NC \\
\hline chr3:151746091-151753763_F & 0.00491668 & NC \\
\hline chr3:34793853-34800591_F & 0.0231231 & NC \\
\hline chr3:36280098-36347798_F & $1.2607 \mathrm{e}-06$ & NC \\
\hline chr3:65729664-65731697_R & 0.0114683 & NC \\
\hline chr3:85783094-85783408_F & $8.04223 e-06$ & NC \\
\hline chr3:90425270-90435820_F & 0.00413759 & NC \\
\hline chr3:96074625-96086375_R & 0.00409835 & NC \\
\hline chr4:135138014-135174889_F & 0.0319769 & NC \\
\hline chr4:138653689-138688814_R & 0.005607 & NC \\
\hline chr4:141527564-141547339_F & $6.95991 \mathrm{e}-07$ & NC \\
\hline chr4:146017200-146029700_F & 0.00357202 & NC \\
\hline chr4:16144314-16144967_F & 0.0213098 & NC \\
\hline chr4:3009566-3009932_R & 0.00919976 & NC \\
\hline chr4:33375464-33377138_R & 0.0668067 & NC \\
\hline chr4:35106125-35127700_R & 0.00619834 & NC \\
\hline chr4:3746945-3747603_F & 0.0204787 & NC \\
\hline chr4:44240894-44241570_R & 0.0143625 & NC \\
\hline chr4:56480568-56658018_R & 0.0140891 & NC \\
\hline chr4:89088538-89130181_F & 0.0201183 & NC \\
\hline chr4:98943050-98959998_R & 0.0168807 & NC \\
\hline chr5:107503800-107515575_R & 0.062443 & NC \\
\hline chr5:113594167-113645342_R & 0.00319634 & NC \\
\hline chr5:125205454-125209470_F & 0.0083657 & NC \\
\hline chr5:14943275-14944205_F & 0.00985262 & NC \\
\hline chr5:15033568-15033987_F & $1.36974 \mathrm{e}-06$ & NC \\
\hline chr5:15146475-15170100_F & 0.0044512 & NC \\
\hline chr5:152006587-152008784_R & $9.41193 e-06$ & NC \\
\hline chr5:22887983-22939658_R & 0.00289087 & NC \\
\hline chr5:74340084-74346709_F & 0.039262 & NC \\
\hline
\end{tabular}




\begin{tabular}{|c|c|c|}
\hline chr5:74487385-74497428_R & $9.40765 \mathrm{e}-07$ & NC \\
\hline chr5:92556322-92558910_F & 0.12272 & NC \\
\hline chr6:108556270-108573161_F & 0.0100175 & NC \\
\hline chr6:121035524-121061074_R & $2.26434 \mathrm{e}-06$ & NC \\
\hline chr6:127111250-127142925_F & $1.64088 \mathrm{e}-05$ & NC \\
\hline chr6:136440100-136450050_F & $2.68846 \mathrm{e}-06$ & NC \\
\hline chr6:140639450-140662200_R & 0.196008 & NC \\
\hline chr6:31007184-31007725_R & $1.67769 \mathrm{e}-05$ & NC \\
\hline chr6:31078802-31079644_R & 0.0104188 & NC \\
\hline chr6:47595238-47601893_F & $8.17804 \mathrm{e}-07$ & NC \\
\hline chr6:47700758-47717846_F & $1.2705 \mathrm{e}-06$ & NC \\
\hline chr6:47967403-47968278_R & 0.101319 & NC \\
\hline chr6:83368261-83407280_R & $7.15038 \mathrm{e}-06$ & NC \\
\hline chr7:129293609-129294172_R & 0.0676957 & NC \\
\hline chr7:134649844-134651551_F & $1.77109 \mathrm{e}-06$ & NC \\
\hline chr7:13533925-13544525_F & 0.0146406 & NC \\
\hline chr7:31709550-31723025_F & 0.0127134 & NC \\
\hline chr7:71231097-71233680_R & 0.0169095 & NC \\
\hline chr8:110197171-110206546_R & $7.97985 \mathrm{e}-07$ & NC \\
\hline chr8:124355710-124401160_R & 0.185143 & NC \\
\hline chr8:124397412-124398022_R & $9.38758 \mathrm{e}-06$ & NC \\
\hline chr8:124569775-124639500_F & 0.00955363 & NC \\
\hline chr8:126268510-126290810_R & 0.00556109 & NC \\
\hline chr8:126396600-126407275_R & 0.00345701 & NC \\
\hline chr8:18587198-18592948_R & $1.26635 \mathrm{e}-05$ & NC \\
\hline chr8:19792940-19798868_F & $8.57724 \mathrm{e}-06$ & NC \\
\hline chr8:26212577-26218527_F & $1.04244 \mathrm{e}-05$ & NC \\
\hline chr8:26212577-26218527_R & $1.8224 \mathrm{e}-05$ & NC \\
\hline chr8:35650475-35664200_F & 0.144477 & NC \\
\hline chr8:48476637-48492537_F & 0.00929962 & NC \\
\hline chr8:59966759-59989065_R & 0.0061802 & NC \\
\hline chr8:73645975-73696275_F & 0.0501734 & NC \\
\hline chr8:85952719-85958369_R & 0.00460826 & NC \\
\hline chr8:87504644-87513694_R & 0.00279074 & NC \\
\hline chr9:102891041-102907200_F & 0.00515525 & NC \\
\hline chr9:20313342-20323517_R & 0.00377583 & NC \\
\hline chr9:31839533-31840971_R & 0.00280048 & NC \\
\hline chr9:68349343-68411643_F & 0.054369 & NC \\
\hline chr9:78104935-78116974_F & 0.0102779 & NC \\
\hline chr9:78107225-78118850_F & 0.0118854 & NC \\
\hline chr9:96635508-96654148_R & 0.00338684 & NC \\
\hline
\end{tabular}




\begin{tabular}{|c|c|c|}
\hline chrX:11693432-11693908_R & 0.00379968 & NC \\
\hline chrX:123306246-123307974_F & 0.0766146 & NC \\
\hline chrX:148803114-148851243_F & 0.192502 & NC \\
\hline chrX:18734106-18744367_R & 0.0105494 & NC \\
\hline chrX:20570399-20571162_F & 0.019669 & NC \\
\hline chrX:75813213-75829323_F & 0.0299943 & NC \\
\hline chrX:91000651-91005855_R & 0.00410192 & NC \\
\hline chrX:92139043-92140820_R & 0.157551 & NC \\
\hline Gm11033 & 0.0224776 & NC \\
\hline Gm19705 & 0.0566135 & NC \\
\hline Gm16159 & 0.0252371 & NC \\
\hline Mir22hg & 0.0323014 & NC \\
\hline Airn & 0.097855 & NC \\
\hline Gm14005 & 0.0159236 & NC \\
\hline Airn & 0.506548 & C \\
\hline Platr28 & 0.0305438 & NC \\
\hline Mirt1 & 0.764632 & C \\
\hline Mirg & 0.029091 & NC \\
\hline Neat1 & 0.0812413 & NC \\
\hline Gm11496 & 0.0157754 & NC \\
\hline Gm14005 & 0.0192137 & NC \\
\hline Gm15850 & 0.0558108 & NC \\
\hline BC051226 & 0.0939098 & NC \\
\hline Gm6507 & 0.232186 & NC \\
\hline Gm11033 & 0.00509673 & NC \\
\hline Gm12576 & 0.427106 & $\mathrm{NC}$ \\
\hline BC051226 & 0.115421 & NC \\
\hline Gm11110 & 0.301507 & NC \\
\hline Neat1 & 0.048226 & NC \\
\hline Gm13021 & 0.0224875 & NC \\
\hline Airn & 0.0138501 & NC \\
\hline Mirt1 & 0.0207367 & NC \\
\hline Tnk2os & 0.54231 & C \\
\hline Gm19705 & 0.0362795 & $\mathrm{NC}$ \\
\hline Snord65 & 0.0338885 & NC \\
\hline Gm14005 & 0.0188855 & $\mathrm{NC}$ \\
\hline Xist & 0.752728 & C \\
\hline Gm14005 & 0.00414661 & NC \\
\hline Neat1 & 0.362236 & $\mathrm{NC}$ \\
\hline Gm14005 & 0.123153 & NC \\
\hline Gm14005 & 0.0208339 & NC \\
\hline
\end{tabular}




\begin{tabular}{|c|c|c|}
\hline Mir22hg & 0.0258004 & NC \\
\hline Gm15850 & 0.0541872 & NC \\
\hline Airn & 0.0273031 & NC \\
\hline Gm12440 & 0.0262182 & NC \\
\hline Gm14636 & 0.0432032 & NC \\
\hline Airn & 0.0355869 & NC \\
\hline Map2k3os & 0.420003 & NC \\
\hline Gm26708 & 0.0205108 & NC \\
\hline BC051226 & 0.126101 & NC \\
\hline Gm11033 & 0.794888 & C \\
\hline Gm4425 & 0.613325 & C \\
\hline Airn & 0.17635 & NC \\
\hline Fam219aos & 0.484752 & NC \\
\hline Gm15850 & 0.143708 & NC \\
\hline Mirt1 & 0.414868 & NC \\
\hline Gm10451 & 0.221146 & NC \\
\hline Gm16062 & 0.352821 & NC \\
\hline Gm19705 & 0.0298838 & NC \\
\hline Gm10069 & 0.537054 & C \\
\hline Igf1os & 0.0735646 & NC \\
\hline Gm14636 & 0.0536528 & NC \\
\hline Gm15226 & 0.179559 & NC \\
\hline Gm15850 & 0.486098 & NC \\
\hline Gm14005 & 0.0235375 & NC \\
\hline Gm16159 & 0.0254402 & NC \\
\hline Xist & 0.764991 & C \\
\hline Gm4262 & 0.0298636 & NC \\
\hline Igf1os & 0.111006 & NC \\
\hline Gm19705 & 0.0426617 & NC \\
\hline Snhg14 & 0.00704251 & NC \\
\hline Mirg & 0.0103937 & NC \\
\hline Snhg14 & 0.0764384 & NC \\
\hline Gm43391 & 0.0199342 & NC \\
\hline Snhg14 & 0.345452 & NC \\
\hline Gm19557 & 0.355901 & NC \\
\hline Snhg14 & 0.0863497 & NC \\
\hline Kcnq1ot1 & 0.843263 & C \\
\hline Cep83os & 0.162767 & NC \\
\hline Snhg14 & 0.0386423 & NC \\
\hline Gm567 & 0.342973 & NC \\
\hline Gm28331 & 0.0644561 & NC \\
\hline
\end{tabular}




\begin{tabular}{|c|c|c|}
\hline Snhg14 & 0.880674 & C \\
\hline Gm20753 & 0.593091 & C \\
\hline Snhg14 & 0.426937 & NC \\
\hline Mirg & 0.131098 & NC \\
\hline Gm43391 & 0.0219136 & NC \\
\hline Mirg & 0.505637 & C \\
\hline Mirg & 0.1437 & NC \\
\hline Snhg14 & 0.0124447 & NC \\
\hline Gm19589 & 0.132223 & NC \\
\hline Gm20324 & 0.654366 & C \\
\hline Snhg14 & 0.0120282 & NC \\
\hline Gm43391 & 0.26049 & NC \\
\hline Mirg & 0.0507224 & NC \\
\hline Gm43672 & 0.0153564 & NC \\
\hline Gm37640 & 0.0652525 & NC \\
\hline Mirg & 0.0203239 & NC \\
\hline Mirg & 0.137655 & NC \\
\hline Gm43391 & 0.0199342 & NC \\
\hline Mirg & 0.0884225 & NC \\
\hline Snhg14 & 0.390361 & NC \\
\hline Gm43391 & 0.26049 & NC \\
\hline Snhg14 & 0.98518 & $C$ \\
\hline Mirg & 0.0463172 & NC \\
\hline Peg13 & 0.213168 & NC \\
\hline Snhg14 & 0.187702 & NC \\
\hline Snhg14 & 0.355111 & NC \\
\hline Mirg & 0.141441 & NC \\
\hline Snhg14 & 0.439997 & NC \\
\hline Mirg & 0.0271403 & NC \\
\hline Snhg14 & 0.0618034 & NC \\
\hline Gm10451 & 0.0540103 & NC \\
\hline Gm14005 & 0.0212908 & NC \\
\hline Gm14005 & 0.0543881 & NC \\
\hline Gm4316 & 0.0332533 & NC \\
\hline Neat1 & 0.0403669 & NC \\
\hline Gm45326 & 0.231246 & NC \\
\hline Gm26708 & 0.0284299 & NC \\
\hline Gm10069 & 0.0847931 & NC \\
\hline Gm4316 & 0.0340033 & NC \\
\hline Gm11110 & 0.185417 & NC \\
\hline Gm10069 & 0.180332 & NC \\
\hline
\end{tabular}




\begin{tabular}{|c|c|c|}
\hline Gm43391 & 0.0219136 & NC \\
\hline Gm26708 & 0.0149551 & NC \\
\hline Gm11110 & 0.0692036 & NC \\
\hline Gm10451 & 0.0210679 & NC \\
\hline Gm11110 & 0.0810488 & NC \\
\hline Gm14005 & 0.0999517 & NC \\
\hline Gm11110 & 0.182985 & NC \\
\hline 1700080N15Rik & 0.0511962 & NC \\
\hline 2610035D17Rik & 0.0555672 & NC \\
\hline B130024G19Rik & 0.00285324 & NC \\
\hline 5031425E22Rik & 0.538575 & C \\
\hline 2610035D17Rik & 0.0561977 & NC \\
\hline 2210408F21Rik & 0.032159 & NC \\
\hline 2210408F21Rik & 0.0159093 & NC \\
\hline D930048N14Rik & 0.947823 & $\mathrm{C}$ \\
\hline 2610035D17Rik & 0.0807057 & $\mathrm{NC}$ \\
\hline 4933438K21Rik & 0.0306206 & $\mathrm{NC}$ \\
\hline 3300005D01Rik & 0.267874 & $\mathrm{NC}$ \\
\hline 3300005D01Rik & 0.0369027 & $\mathrm{NC}$ \\
\hline 1110002L01Rik & 0.108155 & $\mathrm{NC}$ \\
\hline B230206L02Rik & 0.0226174 & $\mathrm{NC}$ \\
\hline 0610009L18Rik & 0.0178113 & $\mathrm{NC}$ \\
\hline A530017D24Rik & 0.136893 & $\mathrm{NC}$ \\
\hline 1810019D21Rik & 0.0222635 & NC \\
\hline 2210408F21Rik & 0.010651 & NC \\
\hline 2610035D17Rik & 0.129329 & NC \\
\hline 9230102O04Rik & 0.0630823 & NC \\
\hline 1700030M09Rik & 0.0569571 & $\mathrm{NC}$ \\
\hline 2210408F21Rik & 0.0671794 & $\mathrm{NC}$ \\
\hline 2210408F21Rik & 0.65975 & C \\
\hline B230206L02Rik & 0.0101435 & $\mathrm{NC}$ \\
\hline 2210408F21Rik & 0.0268647 & $\mathrm{NC}$ \\
\hline 5430416N02Rik & 0.154559 & $\mathrm{NC}$ \\
\hline 1700092C10Rik & 0.0487848 & $\mathrm{NC}$ \\
\hline 2210408F21Rik & 0.0280357 & NC \\
\hline 3300005D01Rik & 0.0212908 & NC \\
\hline 2210408F21Rik & 0.0229185 & NC \\
\hline A730017L22Rik & 0.998392 & C \\
\hline 5730405015Rik & 0.0317178 & NC \\
\hline 3300005D01Rik & 0.372969 & NC \\
\hline 1700080N15Rik & 0.0330213 & NC \\
\hline
\end{tabular}




\begin{tabular}{|c|c|c|}
\hline 1700080N15Rik & 0.0499707 & NC \\
\hline 2210408F21Rik & 0.0460025 & NC \\
\hline 1810019D21Rik & 0.018936 & NC \\
\hline A530017D24Rik & 0.0813244 & NC \\
\hline 1110002L01Rik & 0.776609 & C \\
\hline 2210408F21Rik & 0.018628 & NC \\
\hline D930048N14Rik & 0.451603 & NC \\
\hline 2210408F21Rik & 0.0451752 & NC \\
\hline 1810019D21Rik & 0.048949 & NC \\
\hline 9230102O04Rik & 0.111126 & NC \\
\hline 2500002B13Rik & 0.101008 & NC \\
\hline 2210408F21Rik & 0.0990481 & NC \\
\hline 1110002L01Rik & 0.097498 & NC \\
\hline 5730405015Rik & 0.0204456 & NC \\
\hline 9930014A18Rik & 0.528769 & C \\
\hline A730017L22Rik & 0.0809146 & $\mathrm{NC}$ \\
\hline 2210408F21Rik & 0.0228372 & NC \\
\hline 1110002L01Rik & 0.118036 & $\mathrm{NC}$ \\
\hline B230206L02Rik & 0.0275924 & $\mathrm{NC}$ \\
\hline A730017L22Rik & 0.0278332 & $\mathrm{NC}$ \\
\hline 2210408F21Rik & 0.281572 & $\mathrm{NC}$ \\
\hline 0610038B21Rik & 0.0935767 & NC \\
\hline 4933405E24Rik & 0.0232256 & NC \\
\hline 2210408F21Rik & 0.0572411 & $\mathrm{NC}$ \\
\hline A130077B15Rik & 0.601691 & C \\
\hline 2500002B13Rik & 0.0169935 & NC \\
\hline 6720427I07Rik & 0.00965181 & $\mathrm{NC}$ \\
\hline 2810402E24Rik & 0.0883867 & $\mathrm{NC}$ \\
\hline 9930014A18Rik & 0.328611 & $\mathrm{NC}$ \\
\hline 1700047G07Rik & 0.0070667 & $\mathrm{NC}$ \\
\hline 5031425E22Rik & 0.53656 & C \\
\hline 1700112J16Rik & 0.0307175 & NC \\
\hline B130024G19Rik & 0.111799 & $\mathrm{NC}$ \\
\hline 1700120K04Rik & 0.661745 & $\mathrm{C}$ \\
\hline 1700120G07Rik & 0.114527 & $\mathrm{NC}$ \\
\hline B130024G19Rik & 0.0371643 & NC \\
\hline 1700120G07Rik & 0.00404264 & NC \\
\hline B130024G19Rik & 0.108166 & NC \\
\hline 4930447F24Rik & 0.0835785 & NC \\
\hline 2610016A17Rik & 0.0211952 & NC \\
\hline 9330151L19Rik & 0.243519 & NC \\
\hline
\end{tabular}




$\begin{array}{lcc}\text { 5730419F03Rik } & 0.030601 & \text { NC } \\ \text { 9430078K24Rik } & 0.0824685 & \text { NC } \\ \text { 4930447F24Rik } & 0.120431 & \text { NC } \\ \text { 9430078K24Rik } & 0.0133792 & \text { NC } \\ \text { 1700030M09Rik } & 0.0290032 & \text { NC } \\ \text { 5031425E22Rik } & 0.0306652 & \text { NC } \\ \text { B130024G19Rik } & 0.21339 & \text { NC } \\ \text { B130024G19Rik } & 0.0698227 & \text { NC } \\ \text { 9430078K24Rik } & 0.155534 & \text { NC } \\ \text { 9930014A18Rik } & 0.677781 & \mathrm{C} \\ \text { 5031425E22Rik } & 0.241578 & \text { NC } \\ \text { 1700047G07Rik } & 0.0156654 & \text { NC } \\ \text { 2610016A17Rik } & 0.0145949 & \text { NC } \\ \text { 2610016A17Rik } & 0.0485305 & \text { NC } \\ \text { 5031425E22Rik } & 0.0369786 & \text { NC } \\ \text { 5430416N02Rik } & 0.0140412 & \text { NC } \\ \text { 9930014A18Rik } & 0.187613 & \text { NC } \\ \text { 9530014B07Rik } & 0.0115646 & \text { NC } \\ \text { 5430416N02Rik } & 0.0162011 & \text { NC } \\ \text { 4930447F24Rik } & 0.171856 & \text { NC } \\ \text { 1700112J16Rik } & 0.00978442 & \text { NC } \\ \text { 5430416N02Rik } & 0.0394886 & \text { NC } \\ \text { 0610038B21Rik } & 0.278732 & \text { NC } \\ \text { 4930447K03Rik } & 0.195024 & \text { NC }\end{array}$


Anexo 


\section{Anexo}

\section{Anexo 1 - Certificação da comissão de ética em experimentação animal}

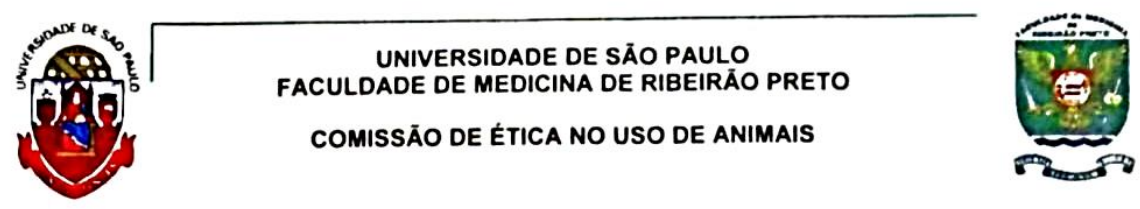

\section{CERTIFICADO}

Certificamos que o Protocolo para Uso de Animais em Experimentaçào $\mathrm{n}^{\circ}$ 006/2016-1, sobre o projeto intitulado "Geração de células timicas epiteliais medulares (mTECs) knockout no gene regulador autoimune (Aire)", sob a responsabilidade do Professor Doutor Geraldo Aleixo da Silva Passos Junior está de acordo com os Princípios Éticos em Experimentação Animal adotado pelo Conselho Nacional de Controle de Experimentação Animal (CONCEA) e foi APROVADO em reunião de 25 de abril de 2016.

We certify that the protocol $n^{\bullet} 006 / 2016-1$ entitled "Generetion of medullany thymic epithetial cells (mTEC) clones knock-out in the autoimmune regulator gen (AIRE)", is in accordance with the Ethical Principles in Animal Research adopted by the National Council for the Control of Animal Experimentation (CONCEA) and was approved by the Local Animal Ethical Committee from the Ribeirào Preto Medical School of the University of Såo Paulo in 04/25/2016

Ribeirão Preto, 25 de abril de 2016.

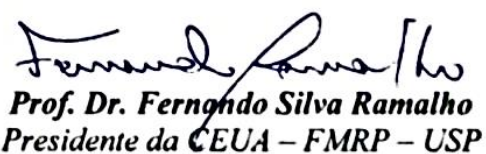

